JULIA KERTESZ RENAULT PINTO 

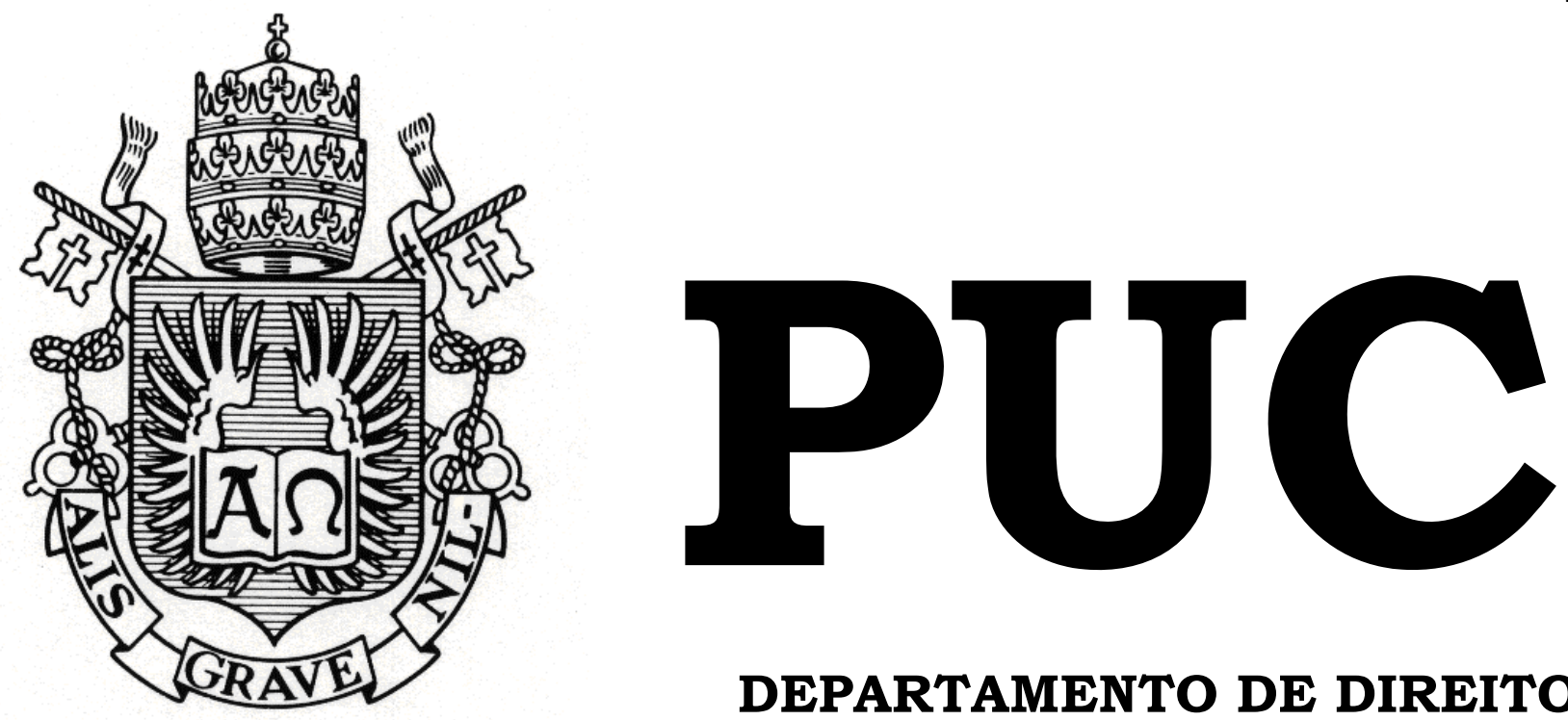

DEPARTAMENTO DE DIREITO

Forças Armadas, Escola Superior de

Guerra e Segurança Nacional

por

JULIA KERTESZ RENAULT PINTO

ORIENTADOR: ADRIANO PILATTI

2010.1

PONTIFÍCIA UNIVERSIDADE CATÓLICA DO RIO DE JANEIRO

RUA MARQUÊS DE SÃO VICENTE, 225 - CEP 22453-900

RIO DE JANEIRO - BRASIL 


\title{
Forças Armadas, Escola Superior de Guerra e Segurança Nacional
}

\author{
por \\ JULIA KERTESZ RENAULT PINTO
}

\begin{abstract}
Monografia apresentada ao
Departamento de Direito da

Pontificia Universidade Católica do

Rio de Janeiro (PUC-Rio) como

requisito parcial para a obtenção do título de Bacharel em Direito.
\end{abstract}

Orientador: Prof. Adriano Pilatti

\section{1}


Para os meus avôs, Magda e Tibor Kertész. 


\section{Agradecimentos}

À minha mãe, pela alegria, compreensão e presença.

Ao meu pai, de espírito atento, pela ajuda afetiva e material.

Às minhas amigas, Duda e Paulinha, pelo apoio, pelo amor e pelo carinho de tantos anos.

Aos companheiros do PET-JUR que contribuíram para que a minha experiência na PUC fosse um encontro alegre e proveitoso. Em especial, Ana Carolina Quintanilha pela meiguice e pelo coração repleto de amor; Taina Gonçalves, minha grande amiga Almodóvar; e Jorge Chaloub amigo sempre presente e disposto para tirar as minhas dúvidas, mesmo as mais primitivas, mesmo sábado de madrugada. Obrigada, queridos.

Ao meu primeiro tutor no PET e, atualmente, meu orientador, Adriano Pilatti, pela ajuda e paciência na construção e organização deste trabalho.

Aos meus queridos amigos do Hillel, dos mais novos aos mais antigos, pelas tantas experiências já compartilhadas, pelo cotidiano repleto de debates, por me ensinarem judaísmo através da amizade e do carinho. Em especial, Dan Dayan, Rafael Leal, Juliana Foguel, Ana Carolina Melman, Michel Gherman, Leonel Caraciki e Elizabeth Scheinkmann.

Aos professores que tornaram este trabalho possível, pelo marco da sabedoria e das contribuições intelectuais ao longo do curso de Direito, como Francisco de Guimaraens, Luiz Emygdio, Augusto Werneck e Fábio Leite.

Por fim, agradeço a CAPES, pela bolsa de estudos ao longo dos três anos em que permaneci no PET- JUR. 


\section{Resumo}

A presente monografia aborda a relação entre a segurança nacional e os militares no Brasil. Pretende-se compreender, num primeiro momento, como, ao longo das Constituições brasileiras, essa relação foi expressa, associada ao contexto internacional e às mudanças dentro do próprio País. Com a Constituição de 1946 e o término da Segunda Grande Guerra, o ambiente que permeou e possibilitou a criação da Escola Superior de Guerra é desenhado. A participação dos militares na criação da Escola, assim como no desenvolvimento da chamada Doutrina de Segurança Nacional, é destacada. Entende-se que, embora a influência e a participação americanas tenham sido cruciais no cenário brasileiro da época, a forma como a segurança nacional foi expressa no Brasil e nos EUA difere substancialmente.

Em seguida, empreende-se o estudo de que como a segurança nacional foi expressa na ditadura militar, através da legislação, da tortura, do desmantelamento das instituições e da desmobilização da sociedade. Conclui-se que a doutrina formulada na Escola Superior de Guerra teve uma íntima relação com os militares, e serviu de base e justificativa para os anos mais autoritários que o Brasil já viveu.

\section{Palavras- chave}

Segurança nacional e Desenvolvimento. Forças Armadas. Guerra Fria: capitalismo e comunismo. Escola Superior de Guerra. Inimigo interno. Ditadura Militar. Legislação de Segurança Nacional. 


\section{Sumário}

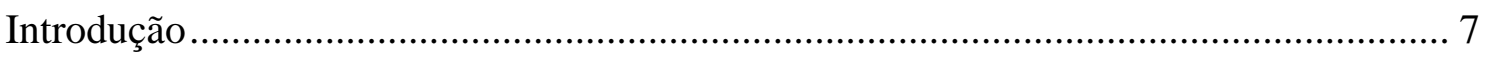

1. Os militares e a segurança nacional: uma retrospectiva brasileira ............................ 12

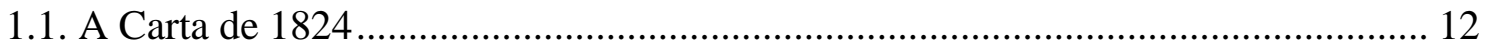

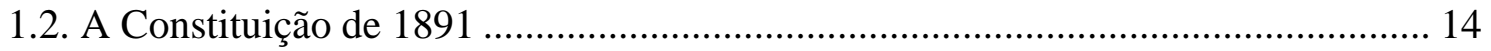

1.2.1. A Missão Militar Francesa na Primeira República................................................. 16



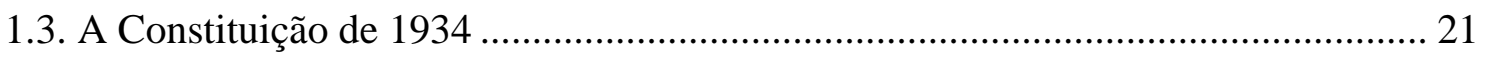

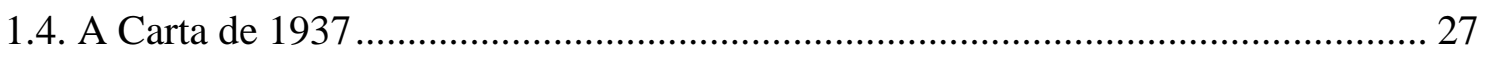

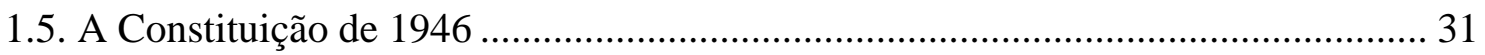

2. Os militares e a Escola Superior de Guerra: presságios de um golpe ......................... 34

2.1. A criação da Escola Superior de Guerra....................................................................... 34

2.2. A Escola Superior de Guerra e a construção de uma doutrina ................................. 43

3. O objetivo e o propósito: a ditadura militar e a segurança nacional.......................... 58

3.1. 1964-1967: a segurança nacional antes dos anos de chumbo................................. 58

3.2. Entre 1968 e 1974: a segurança nacional nos anos de chumbo.............................. 68

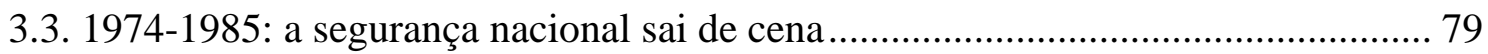

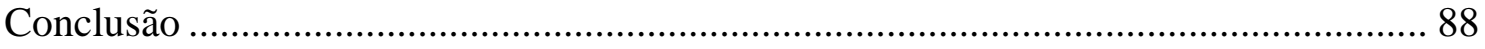

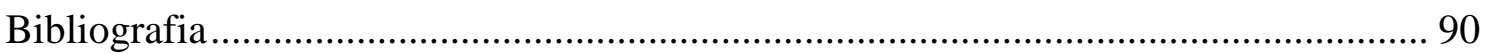

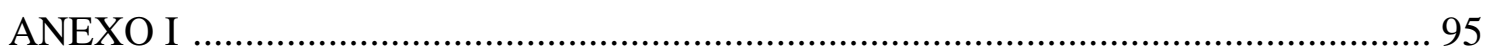




\title{
Introdução
}

\begin{abstract}
"Realmente eu vivo num tempo sombrio Que tempo é este em que uma conversa sobre árvores chega a ser uma falta, pois implica em silenciar sobre tantos crimes? Vínhamos nós então mudando de país mais do que de sapatos em meio às lutas de classes, desesperados, enquanto apenas injustiça havia e revolta nenhuma. Mas vós, quando chegar a ocasião de ser o homem um parceiro para o homem, pensai em nós com simpatia."

(Bertolt Brecht - Aos que vão nascer)
\end{abstract}

É sobre um dos conceitos mais controversos da história brasileira, a segurança nacional, que recai o objeto desse trabalho. Pretende-se fazer um estudo de como esse tema associado à organização militar ajudou na construção de uma doutrina e de um projeto militar, assim como nos permite compreender a forma autoritária como foram tratados, não apenas no período anterior à Escola Superior de Guerra, mas, principalmente, após a sua criação. É sobre esse momento posterior que se debruça nosso trabalho.

A segurança nacional sempre esteve associada, pela maior parte da literatura, como um fenômeno típico da Guerra Fria. Sem descartamos a importância deste entendimento, preferimos compreendê-la como uma política de Estado ${ }^{1}$ que começou a ser formulada no Brasil a partir do século XIX, e que encontrou, ao longo do século XX, os militares como seus principais defensores.

Segundo Maria Helena Moreira Alves, "as origens da ideologia de segurança nacional vinculam-se a teorias geopolíticas, ao antimarxismo e às tendências conservadoras do pensamento social católico, tal como a Opus Dei e a Action Française." 2

Até os anos 1950, no Brasil, não havia um desenho claro sobre o que defesa, segurança, segurança nacional e defesa do Estado, de fato, significavam. Todos esses conceitos foram usados até então sem que neles encontrássemos

\footnotetext{
${ }^{1}$ D’ARAUJO, Maria Celina. Justiça Militar, Segurança Nacional e Tribunais de Exceção. Trabalho apresentado no $30^{\circ}$ encontro da ANPOCS, 24 a 28 de outubro de 2006. Caxambu, Minas Gerais.

2 ALVES, Maria Helena Moreira. Estado e Oposição no Brasil (1964-1984), p. 33. 3aed. Petrópolis: Vozes, 1985. $337 \mathrm{p}$.
} 
significados bem definidos. Foi a Guerra Fria que gerou a necessidade de elaboração desses conceitos, embora entendamos que a segurança nacional já estava presente antes de 1964, assim como o caráter intervencionista dos militares.

Queremos justamente compreender como a segurança nacional em seu momento de aprimoramento conceitual, após a criação da Escola Superior de Guerra em 1949, contribuiu para o projeto autoritário dos militares, e como da ESG saíram boa parte dos militares responsáveis pelo golpe em 1964. Da mesma forma como aconteceu em outros países da América Latina, houve uma militarização do tema (segurança nacional), de modo que "nem mesmo a redemocratização dos anos 80 conseguiu superar". ${ }^{3}$

É importante analisar, ao longo do trabalho, as produções legislativas que consideramos mais relevantes, tal como os Atos Institucionais, as Constituições brasileiras e as inúmeras Leis de Segurança Nacional, para compreendermos de que forma a segurança nacional ecoou no mundo jurídico.

Essa monografia não pretende, contudo, esgotar todos os inúmeros sentidos que permeiam o conceito de segurança nacional, nem tampouco explicar todos os eventos que envolveram os militares no Brasil. Não haveria tempo suficiente, e não entendemos ser esse o objeto do trabalho.

Defendemos que os estudos sobre os militares e a sua íntima relação com a segurança nacional ainda se justificam, embora a realidade brasileira e mundial, que antecipou e permeou a ditadura militar, tenha ficado para trás. A Guerra Fria chegou ao fim, o comunismo não está mais em pauta. O perigo vermelho, "maior inimigo da civilização cristã” ${ }^{4}$, e a possibilidade de uma revolução nos moldes soviéticos não aparecem mais no contexto da atualidade.

\footnotetext{
${ }^{3}$ D’ARAUJO, Maria Celina. Op. cit.

${ }^{4}$ Discurso de Getúlio Vargas. Apud: FAUSTO, Boris. Getúlio Vargas, p. 75. São Paulo: Companhia das Letras, 2006, 233 p.
} 
Mas, não se pode abafar a história “aos que vão nascer" 5 . O período militar deixou marcas profundas, violentas. Famílias de torturados e mortos ainda aguardam informações sobre as vítimas. O comando das Forças Armadas persiste em ocultar arquivos, ao mesmo tempo em que resiste na inexistência de documentos. Apesar das mudanças positivas no Brasil, entendemos que o passado não pode se perder, não pode ser esquecido. É preciso conservar a memória, e conservando-a podemos aprender com a experiência, de modo que se possa evitar que eventos como o do golpe de 1964 se repitam, seja em nome da segurança nacional embasada em um anticomunismo ferrenho, seja em prol de qualquer outra doutrina, que ameace tirar de nós as liberdades que demoramos tanto para conquistar.

A monografia está organizada em três capítulos. O primeiro capítulo trata da relação estabelecida entre os militares e a segurança nacional até a Constituição de 1946. Faremos, portanto, uma análise a partir, principalmente, das Constituições brasileiras e das principais Leis de Segurança Nacional. Iremos com isso delineando o campo de atuação dos militares e as suas principais participações políticas dentro de cada período, de modo a compreendermos que nem o golpe de 1964 foi a única intervenção da qual participaram, embora tenha um caráter singular importantíssimo, nem a segurança nacional foi um conceito tão novo assim, que teria surgido apenas com a Guerra Fria.

Dessa forma, o primeiro capítulo está dividido em cinco tópicos. O primeiro, 1.1, trata da Carta de 1824, e, portanto, do período Imperial brasileiro. Buscamos compreender como as Forças Armadas são vistas neste primeiro momento, e como o conceito de segurança aparece na legislação da época. O segundo tópico, 1.2, trata da relação entre os militares e a segurança na Constituição de 1891. Interessa-nos como essa relação se deu ao longo da Primeira República, assim como as principais influências dos militares nesta época, tal como a Missão Militar Francesa.

\footnotetext{
5 BRECHT, Bertolt. Aos que vão nascer. Disponível em http://www.apropucsp.org.br/revista/r20_r15.htm. Acesso em 2 de maio de 2010.
} 
A Constituição de 1934 (1.4), assim como a Carta de 1937 (1.5), marcam um momento extremamente importante para os militares e para o desenvolvimento do conceito de segurança nacional. A década de 1930 revela mudanças significativas, com o aumento do poder político dos militares, com o crescente medo do comunismo no Brasil, levando a diversas medidas repressivas, principalmente, durante o Estado Novo. Foi na década de 1930 que o mundo vivenciou a segunda das suas Grandes Guerras, na qual o Brasil terminou por apoiar as forças norte-americanas. Com o fim da Guerra e do Estado Novo, uma nova Constituição. No último tópico (1.6), trataremos da Constituição de 1946 e da Lei de Segurança Nacional de 1953, que seria revogada em 1967.

Lançadas as bases para a compreensão da relação entre os militares e a segurança, prosseguiremos, no segundo capítulo, com a criação da Escola Superior de Guerra (2.1), fundada durante a vigência da Constituição de 1946 e durante o governo do General Eurico Gaspar Dutra. A partir da criação da ESG, faremos relações com a influência norte-americana proveniente da $2^{\text {a }}$ Guerra, com a Guerra Fria, com a necessidade de aprimoramento dos altos oficiais das Forças Armadas e com a elaboração da Doutrina de Segurança Nacional e Desenvolvimento. No segundo tópico (2.2), trataremos especificamente da Doutrina, pois a partir dela surge o grande propósito que embasou o golpe de 1964: segurança interna e desenvolvimento econômico baseado no capital estrangeiro. Desenvolveremos os principais conceitos estudados e compilados pela ESG, que tornaram possível a construção do binômio segurançadesenvolvimento, o grande pilar da ditadura militar.

Aprimorado o conceito de segurança nacional, cujo nome a ESG alterou para Doutrina de Segurança Nacional e Desenvolvimento, surgem os Atos Institucionais, as Leis de Segurança Nacional, a repressão e a perseguição. No terceiro capítulo, trataremos do período da ditadura militar, compreendido entre 1964 e 1985. Abordaremos as diversas formas pelas quais a segurança nacional é expressa, seja na legislação, seja na montagem do aparelho repressivo. Destacaremos também a influência da Doutrina formulada na ESG na 
mentalidade e comportamento militares, levando a corporação à desordem e indisciplina.

No primeiro tópico, trataremos do momento inicial da ditadura entre 1964, com o golpe que depôs o Presidente João Goulart, até o fim do mandato do Presidente Castello Branco, em 1967 (3.1). Em seguida, analisaremos o período que abrange os chamados anos de chumbo com o Marechal Costa e Silva na Presidência e, posteriormente, com o Presidente Medici. Os anos em que o General Medici governou o País, sob a vigência do AI-5, foram marcados pela extrema violência e repressão (3.2). Seu sucessor, o General Geisel, começou o processo lento e gradual de abertura do País, culminando na saída do último presidente militar, o General João Figueiredo, em 1985 (3.3). Após o último capítulo, seguem as conclusões. 


\section{Os militares e a segurança nacional: uma retrospectiva brasileira}

"Por não reconhecer a índole da instituição, falácia dos intérpretes, dos sociólogos e historiadores, vêem no conteúdo de cada intervenção o caráter da força armada, esquecidos de pesquisar-lhes, no processo, a conduta ao longo do tempo.”

(Raymundo Faoro - Os donos do poder)

\subsection{A Carta de 1824}

A Carta de 1824 falava em “segurança”, estabelecendo no art. 102, inciso $\mathrm{XV}$ :

Art. 102. O Imperador é o Chefe do Poder Executivo, e o exercita pelos seus Ministros de Estado.

São suas principais atribuições

$\mathrm{XV}$. Prover a tudo, que for concernente á segurança interna, e externa do Estado, na forma da Constituição (grifos nossos)

As noções de segurança interna e externa estão presentes, embora não haja menção a nenhuma lei especial. A Justiça Militar era até então representada pelo Conselho Superior Militar e de Justiça. Era presidido pelo Imperador, não fazendo parte do Poder Judiciário, o que só ocorrerá com a Constituição de 1934.

A Carta de 1824 já faz menção aos “inimigos internos”. O art. 145 estabelece que: “todos os Brasileiros são obrigados a pegar em armas, para sustentar a Independência, e integridade do Império, e defendê-lo dos seus inimigos externos, ou internos” (grifos nossos).

Cabe ressaltar que a Constituição de 1824 foi a única na história brasileira que não atribuiu aos militares poderes para resolver conflitos internos e proteger a ordem pública. O art. 147 fala que “a Força Militar é essencialmente obediente; jamais se poderá reunir, sem que lhe seja ordenado pela Autoridade legitima”, o Imperador, e que ele era competente para "privativamente empregar a Força 
Armada de Mar, e Terra, como bem lhe parecer conveniente á Segurança, $e$ defesa do Império" ${ }^{6}$ (grifos nossos).

A Carta de 1824 procurou manter as três linhas que definiam a estrutura oficial militar: a primeira era a tropa regular e paga, a segunda e a terceira eram as milícias e ordenanças, auxiliares e gratuitas. O Exército era, então, responsável pela defesa das fronteiras e as milícias eram responsáveis pela ordem pública nas comarcas, embora estas tenham sido, posteriormente, substituídas pela Guarda Nacional. É que as Forças Armadas dispunham de uma enorme missão: preservar um país de tamanhos continentais, com regiões tão distintas e distantes umas das outras, e as suas fronteiras. Dessa gigante missão e da impossibilidade de cumpri-la, surgiu a necessidade, para a autoridade, da criação de instrumentos militares que não as Forças Armadas. ${ }^{7}$

Durante o Império, a elite política adotou uma série de atitudes extremamente hostis à existência de uma força armada profissional e permanente. A criação da Guarda Nacional foi apenas uma delas. Suspeitava-se que os comandantes militares não se identificariam com os interesses regionais, ao contrário das forças milicianas compostas por cidadãos. O Exército, nessa época, ainda era visto como parte das tropas coloniais portuguesas, não vinculado, portanto, ao projeto de independência.

Essa circunstância apenas começa a se modificar quando, após a Guerra do Paraguai, o Exército surge como uma força organizada ao nível da Guarda Nacional, ao mesmo tempo em que se encontra decepcionada com a sua posição de poder dentro da sociedade. Segundo Nelson Werneck Sodré ${ }^{8}$, se tardia foi a formação de ascensão da burguesia nacional, tardia foi a formação das Forças Armadas brasileiras, já que de instrumento inadequado do latifúndio, vão se tornando instrumento da burguesia, participando inclusive das transformações em que esta participa.

\footnotetext{
${ }^{6}$ Art. 148 da Carta de 1824

${ }^{7}$ SODRÉ, Nelson Werneck. A história militar do Brasil, p. 89. 3ªed. Rio de Janeiro: Civilização Brasileira, 1979. $439 \mathrm{p}$.

${ }^{8}$ Ibid. p. 232.
} 
O fato é que, ao longo do Império, surge um movimento, composto por oficiais inconformados, dentro do Exército que, diferenciando-se social e intelectualmente da elite civil, encontra-se insatisfeita, não apenas com a situação do País, mas com a sua posição de poder e prestígio. Esses oficiais forneceram a liderança que, em 1889, interveio no País. ${ }^{9}$

\subsection{A Constituição de 1891}

A idéia de segurança nacional vai se acentuando e ganhando novos contornos com o aparecimento de novos atores na sociedade brasileira. A concepção de um inimigo a ser combatido, inimigo estranho, portanto, e ameaçador de uma suposta ordem estabelecida surge antes mesmo da corrente comunista ingressar ideologicamente no Brasil. O trabalho industrial, a presença do imigrante e a organização sindical que daí começava a ser montada foram os primeiros grandes inspiradores da doutrina brasileira de segurança nacional.

Com o advento da República, os militares ganham mais espaço evidenciado pela Constituição de 1891 no seu art. 14:

Art. 14 - As forças de terra e mar são instituições nacionais permanentes, destinadas à defesa da Pátria no exterior e à manutenção das leis no interior. A força armada é essencialmente obediente, dentro dos limites da lei, aos seus superiores hierárquicos e obrigada a sustentar as instituições constitucionais.

A mudança de regime inaugurada com a primeira República, também chamada República Velha, trouxe para o Exército uma ruptura com os antigos vínculos de dependência com a sociedade civil. Começa a aparecer a consciência de sua condição militar, ao mesmo tempo em que a existência do Exército vincula-se a de uma entidade única e particular na sociedade brasileira. Não havia, contudo, uma concepção militar clara quanto ao seu papel na sociedade, exceto algumas vagas pontuações a uma missão regeneradora da sociedade civil, que lhes parecia deteriorada e moralmente inferior. O Marechal Floriano falava da necessidade de uma ditadura no País: “como liberal que sou não posso querer

\footnotetext{
${ }^{9}$ CARVALHO, José Murilo de. Intervenção Militar começou no Império, p. 154. In: Forças Armadas e Política no Brasil. Rio de Janeiro: Zahar, 2005, p. 153-155.
} 
para o meu país o governo da espada, mas não há quem desconheça, e aí estão os exemplos, de que é ele o que sabe purificar o sangue do corpo social que como o nosso está corrompido (...)” ${ }^{10}$.

Não obstante, a República trouxe com ela novos inimigos, os inimigos da República, os monarquistas, temidos, principalmente, pelos militares. Foi devido a esses inimigos que se editou, em 23 de dezembro de 1889, o decreto $\mathrm{n}^{\circ} 85-\mathrm{A}$, conhecido como "decreto-rolha". Foi a primeira lei de imprensa republicana, cujo objetivo era, basicamente, instituir a censura e julgar os responsáveis pelo abuso das manifestações de pensamento. O decreto também falava na punição de civis e militares envolvidos em atos comprometedores da nova ordem política. Os responsáveis pelo julgamento integravam a Comissão Mista Militar de Sindicâncias e Julgamentos e seriam indicados pelo Ministro de Guerra.

Outro decreto que merece atenção é o dec. 1641/1907, que "trata da expulsão de estrangeiros que comprometerem a segurança nacional ou a tranqüilidade pública e dá outras providências" (grifos nossos). Foi a principal lei repressiva contra os anarquistas e militantes sindicais e tratou, principalmente, da expulsão de operários estrangeiros envolvidos em agitações.

José Murilo de Carvalho ${ }^{11}$ atenta para o fato de que a Primeira República delimita-se pelos parênteses de duas intervenções militares. No período entre 1831 e 1889, o Brasil não presenciou qualquer crise política nacional provocada por interferência das Forças Armadas, logo a mudança verificada na Primeira República já demonstra as transformações ocorridas na organização militar, especialmente, um aumento significativo de poder político.

A República vai deixando mais clara a tendência para que a defesa e a segurança se tornassem questões militares. Com a Constituição de 1891, o Brasil abre as portas para que as Forças Armadas sejam também as responsáveis pela manutenção da ordem interna do País, precedente este que só se enfatizará mais ao longo das demais Constituições. Começa, então, um movimento de aumento

\footnotetext{
${ }^{10}$ Transcrito em Tobias Monteiro. Pesquisas e Depoimentos. Apud: COELHO, Edmundo Campos. Em busca de Identidade: o Exército e a Política na Sociedade Brasileira, p. 68. Rio de Janeiro: ForenseUniversitária, 1976. 207 p.

${ }^{11}$ CARVALHO, José Murilo de. As Forças Armadas na Primeira República, p. 13-14. In: Forças Armadas e Política no Brasil. Rio de Janeiro: Zahar, 2005, p. 13-61.
} 
de poder dos militares, que passarão a chamar para si o dever de resguardar a segurança, a lei e a ordem. Segundo Raymundo Faoro:

Daí por diante, as intervenções da força armada, ainda quando reclamadas por civis, teriam a mácula da ilegitimidade, baseadas num estado de emergência não previsto em lei, transitório por essência, que seria necessário afastar, logo que serenado o céu. (...) A força armada, o Exército, sobretudo, identifica-se à missão de preservar a unidade e a homogeneidade nacionais, exacerbadas nos modelos simbólicos da pátria. ${ }^{12}$

\subsubsection{A Missão Militar Francesa na Primeira República}

A missão militar francesa chegou ao Brasil, em 1920, contratada pelo ministro civil, Calógeras. O Estado-Maior do Exército preferia que a missão tivesse um papel meramente de consultora, mas seus efeitos foram profundos e duradouros. O seu maior impacto foi na formação de bons oficiais de EstadoMaior. Criado em 1896, em substituição à antiga Repartição do AjudanteGeneral, o Estado-Maior do Exército não exercia seu papel de formulador da política de defesa nacional, já que não havia sequer um plano nacional de defesa. A principal preocupação era com as fronteiras do Sul e Sudeste.

Uma nova visão de defesa nacional só começaria a circular no Brasil após a volta, da Alemanha, de diversos jovens oficiais, chamados pejorativamente de "jovens turcos" ${ }^{13}$. A campanha empreendida pelos "jovens turcos" tinha por objetivo, principalmente, o aperfeiçoamento profissional do Exército. Faltava justamente uma formação apropriada dos oficias de Estado-Maior e a reestruturação do órgão para que fosse possível a implantação de uma nova doutrina. Foi a Missão Militar Francesa que tornou essa implantação possível. ${ }^{14}$

A Missão Militar Francesa, MMF, foi incumbida da direção da Escola de Aperfeiçoamento de Oficiais (EsAO), para capitães e tenentes, do curso de

\footnotetext{
${ }^{12}$ FAORO, Raymundo. Os donos do poder, p. 624. São Paulo: Globo, 2008. 929 p.

13 Um grupo de oficiais, por sugestão do Ministro Rio Branco e com o apoio do Ministro de Guerra, Hermes da Fonseca, foram enviados para servirem arregimentados na Alemanha, cujo Exército era considerado um dos melhores da época. O envio desses oficiais fazia parte de um projeto de modernização do Exército, no qual o Marechal Hermes da Fonseca era o grande responsável. A esse grupo de oficiais deu-se pejorativamente o nome de "jovens turcos".

${ }^{14}$ CARVALHO, José Murilo de. As Forças Armadas na Primeira República, p. 28-29.
} 
Estado-Maior e o de Revisão de Estado-Maior. Editou regulamentos do ensino militar, planos e diretrizes para a formação do oficial do Exército.

Evidente que a reformulação do Estado-Maior do Exército representou maior coesão e centralização. A mudança também permitiu uma extraordinária expansão da noção do escopo do papel do Exército, de modo que “ $a$ nova concepção de defesa abrangia todas as dimensões relevantes da vida nacional, desde a preparação militar propriamente dita até o desenvolvimento de indústrias estratégicas” ${ }^{15}$.

Por influência da Missão, foi criado o Conselho de Defesa Nacional, em 1927, com o objetivo de elaborar um plano de mobilização nacional para a defesa do Brasil e uma melhor definição das operações militares do Exército no País.

A Missão Militar dividiu ideologicamente os oficiais da época. Aqueles que eram contra a intervenção das Forças Armadas na política seguiram os ensinamentos da Missão Militar Francesa. O próprio Góes Monteiro, ex-aluno da MMF, defendeu essa posição antes dos anos 1930: “Nas lutas políticas, o Exército não deve passar do grande mudo - condição essencial de sua coesão e eficiência e até mesmo de sua existência como instituição. Sua verdadeira e única política é a preparação para a guerra." 16

É importante ressaltar que, embora a campanha dos “jovens turcos” tenha adquirido à época grande repercussão, o programa de profissionalização do Exército não se confunde com os valores indicados no seu conteúdo. A idéia de apolitismo militar, de um Exército apesar das regras do jogo político, totalmente voltado para a defesa externa não foi aceita. A artificialidade dessa tese torna-se clara quando atentamos para o fato de que os mais ardentes defensores dessa corrente, os jovens turcos, se viram, posteriormente, totalmente imersos em jogos e conspirações políticas. A tendência dos militares voltava-se para o controle do poder político que, ao mesmo tempo, visasse a regeneração da sociedade civil. ${ }^{17}$

\footnotetext{
${ }^{15}$ Ibid. p. 29.

${ }^{16}$ CARVALHO, José Murilo. Forças Armadas e Política, 1930-1945, p. 74. In: Forças Armadas e Política no Brasil. Rio de Janeiro: Zahar, 2005, p. 62-101.

${ }^{17}$ COELHO, Edmundo Campos. Op. cit., p. 82-83.
} 
A MMF intensificou a profissionalização e a modernização do Exército. Mesmo que, para os "jovens turcos”, o exército alemão ainda fosse o grande modelo digno de inspiração, a ascendência francesa resultante do desfecho da I Guerra Mundial trouxe a possibilidade do conhecimento de outros modelos de organização e de estratégias militares. A MMF deixou ainda "numerosa bibliografia e desenvolveu entre a oficialidade brasileira o gosto pelo estudo de assuntos estratégicos, contribuindo para o desenvolvimento do pensamento militar brasileiro". ${ }^{18}$

\subsubsection{O Tenentismo}

Durante a década de 1920, no Brasil, em meio a campanhas modernizadoras do Exército, tal como a Missão Militar Francesa citada anteriormente, surge, dentro da oficialidade, um movimento que seria conhecido como Tenentismo.

Exaustivamente tratado na literatura, o Tenentismo revelou-se um centro importante de oposição à hegemonia cafeeira, com um projeto radical de assumir o poder político pelo caminho das armas. Sua importância é, muitas vezes, ressaltada pelo significante papel que assumiram na chamada Revolução de 1930, que depôs o presidente Washington Luís, encerrando o período chamado de República Velha, e pelos postos que ocuparam nos governos seguintes. ${ }^{19}$

Essa nova questão militar foi deflagrada por um episódio no qual uma carta, supostamente escrita por Arthur Bernardes, enunciava opiniões ruins sobre o Exército. Da carta, surgiu a insatisfação, não por parte dos oficiais mais antigos, mas por parte de um grupo de jovens oficiais, composto em sua maioria por tenentes, e liderados pelo Marechal Hermes da Fonseca.

Em 1922, a Escola Militar do Realengo, o Forte de Copacabana e a guarnição local de Mato Grosso rebelaram-se. Em 1924, haveria outra rebelião

\footnotetext{
18 AGUILAR, Sérgio Luiz Cruz. A Parceria Estratégica Brasil-França na Área da Defesa. Disponível em www2.uel.br. Acesso em 02 de maio de 2010.

${ }^{19}$ FAUSTO, Boris. A Revolução de 1930- Historiografia e História, p. 80-81. 16 ${ }^{\text {a }}$ Ed. São Paulo: Companhia das Letras, 2008. 159 p.
} 
em resposta às punições recebidas pelos oficiais, que participaram do movimento de 1922. Em 1930, os tenentes conseguiriam, em aliança com o Rio Grande do Sul, depor o presidente e encerrar a República Velha. Quase toda a liderança de 1930 proveio de oficiais envolvidos no episódio de 1922, entre eles: Joaquim e Juarez Távora, Siqueira Campos, Luis Carlos Prestes, Eduardo Gomes, João Alberto, Nunes de Carvalho, Miguel Costa. ${ }^{20}$

Segundo Nelson Werneck Sodrée ${ }^{1}$, o Tenentismo passou por três fases: a primeira é composta apenas por militares, que operam isoladamente. Reveste-se, no seu conteúdo, com o propósito da luta armada. A segunda é composta por militares aliados a oposições políticas locais ou regionais, em particular o Rio Grande do Sul, alcançando uma amplitude maior. Na terceira fase, o vínculo será com a oposição federal, envolvendo a questão da sucessão presidencial de Washington Luís, que terminará com a sua deposição.

Para Elio Gaspari:

Terrível geração, a dos ‘tenentes’ dos anos 20. Estavam prontos para salvar o Brasil dos 'casacas', nome que davam à elite civil que governava o país desde o Império. Movidos por um militarismo ressentido e salvacionista, rebelaram-se em 1922 e 24 em nome da moralidade pública. Autoritários e audaciosos, eram dissidentes em busca de um ditador. Havia neles mais revolta do que radicalismo político, até porque sabiam pouco. 22

Importantes militares, que ocuparam papéis relevantes na história brasileira, participaram do movimento tenentista das décadas de 1920 e 1930. Góes Monteiro e Gaspar Dutra foram dois dos principais militares do Estado Novo. Apoiaram o governo, em 1937, e o cancelaram, em 1945. Geisel e Golbery teriam intensa participação na Escola Superior de Guerra, criada em 1949. Juntos conspirariam contra o presidente João Goulart, na década de 1960, apoiariam a ditadura militar, em 1964, e seriam os principais responsáveis, na década de 1970, para que ela chegasse ao fim. Sobre o Tenentismo e o contexto da época, Geisel relata:

\footnotetext{
${ }^{20}$ CARVALHO, José Murilo de. Forças Armadas na Primeira República, p. 49.

${ }^{21}$ SODRÉ, Nelson Werneck. Op. cit., p. 213.

${ }^{22}$ GASPARI, Elio. A Ditadura Derrotada, p. 33. $2^{\mathrm{a}}$ reimpressão. São Paulo: Companhia das Letras, 2003. $538 \mathrm{p}$.
} 
No fim do século passado, o Exército se esforçou para ganhar a Guerra do Paraguai. Fomos para lá sem tropa treinada, sem equipamento e sem grande apoio, mas vencemos. Quando a tropa voltou, descobriu que os 'casacas' não lhe davam importância. Além disso, formou-se um sistema de ensino muito eficiente, talvez mais eficiente do que devesse ser para tamanha falta de meios. Os oficiais iniciaram-se nas idéias positivistas, começaram a discutir a validade do poder nas mãos dos 'casacas', e proclamou-se a República. Primeiro veio o Deodoro, depois o Floriano (...). Depois do Floriano, os 'casacas' retomaram o poder, e aos poucos formou-se aquele clima de agitação que resultou na Revolução de $1930 .{ }^{23}$

Podemos dizer que, durante a Primeira República, três correntes ideológicas foram apresentadas para justificar o intervencionismo militar: o soldado cidadão, ou a intervenção reformista, o soldado profissional, ou a nãointervenção e o soldado-corporação ou a intervenção moderadora. ${ }^{24}$

O soldado cidadão envolve a idéia de cidadão fardado, ao qual não se pode negar o direito de participar da vida política do país. O soldado devia assumir a sua cidadania plena, sem deixar de ser cidadão. A idéia positivista do soldado como “o cidadão armado cooperador do progresso" ${ }^{25}$ passa a ser entendida como a necessidade de fortalecer o Exército, diante da exigência do progresso. Ocorre que, muitas vezes, para fortalecer o Exército, rompia-se com a disciplina e com a hierarquia. Assim foi em 1922 e na Revolução de 1930 quando os tenentes, por não pertencerem aos altos escalões, viram-se num impasse hierárquico. A promoção rápida dos tenentes, como ocorreu com Góes Monteiro, quando foi promovido a general, serviu para amenizar esse problema. A corrente do soldado profissional tentaria resolver estes impasses.

A segunda corrente, do soldado profissional, visava, unicamente, a profissionalização dos militares, com o afastamento destes da política e dos cargos públicos. Seu principal representante foi Leitão de Carvalho, fortemente influenciado pela Missão Militar Francesa. Acreditava-se que o envolvimento

\footnotetext{
${ }^{23}$ Ibid. p, 34.

${ }^{24}$ CARVALHO, José Murilo de. Forças Armadas na Primeira República, p. 40-43.

${ }^{25}$ A frase de Benjamin Constant remete-se à idéia positivista, na qual a diferença entre soldados e civis deveria ser reduzida, a ponto de extinguir-se o soldado em prol do cidadão. Após a República, no entanto, essa concepção tiraria dos militares positivistas qualquer possibilidade de atuação política. Por isso, muitos deles aderiram à concepção de soldado-cidadão, envolvendo as idéias positivistas num caráter intervencionista. (CARVALHO, José Murilo de. Forças Armadas na Primeira República, p. 39)
} 
dos militares na política quebrava o princípio de hierarquia na corporação, levando à desordem. O soldado profissional seria aquele apenas voltado para a defesa externa do país, sem qualquer posicionamento político. Como tratamos no tópico 1.2.1, essa tese nunca foi, de fato, recebida pelos oficiais brasileiros.

A terceira corrente, do soldado-corporação, defendia a intervenção dos militares na política e a profissionalização da corporação. Ao contrário da concepção de soldado-cidadão, que acreditava na intervenção independente da organização ou mesmo contra ela, essa corrente defendia a intervenção através da organização, orientada por um órgão de cúpula, o Estado-Maior do Exército.

Tinha-se, então, um intervencionismo de generais, da organização, e não apenas de alguns segmentos militares. Essa corrente aparece com muita exatidão a partir dos anos 1930, como veremos nos próximos tópicos, quando os movimentos perpetrados por oficiais, que não pertenciam à cúpula militar, eram sempre rigidamente abafados e reprimidos pela própria cúpula, que buscava a coesão e a homogeneização da corporação, adaptada aos valores dos oficiais superiores.

Segundo José Murilo de Carvalho ${ }^{26}$ : “A mudança no papel do Exército foi lenta, mas ainda permitiu que os tenentes de 1922, interventores reformistas, se transformassem, quando generais, em interventores moderadores.”

\subsection{A Constituição de 1934}

Na Constituição de 1934 verificam-se diversas modificações importantes, entre elas um título com nove artigos dedicado à Segurança Nacional e uma sessão dedicada à Justiça Militar, vinculando-a ao Poder Judiciário. O art. 84 cria a possibilidade de equiparação de civis a militares em casos de crime contra a segurança externa do país, dotando a Justiça Militar de um caráter de Justiça Especial, caráter este que ficará mais acentuado com a aprovação da Lei de Segurança Nacional em 1935. Foi criado também o Conselho Superior de

\footnotetext{
${ }^{26}$ CARVALHO, José Murilo de. Forças Armadas na Primeira República, p. 42.
} 
Segurança Nacional que, a partir da Constituição de 1946, passaria a se chamar Conselho de Segurança Nacional (CSN). Embora, a criação do Conselho já denote uma preocupação com o tema da segurança, ele só passará a ser de fato um centro expressivo de poder durante a Ditadura Militar. O art. 162 já fala em ordem como uma das destinações das Forças Armadas. Transcrevemos abaixo os artigos referidos para maior compreensão:

Art. 84 - Os militares e as pessoas que lhes são assemelhadas terão foro especial nos delitos militares. Este foro poderá ser estendido aos civis, nos casos expressos em lei, para a repressão de crimes contra a segurança externa do país, ou contra as instituições militares.

Art. 159 - Todas as questões relativas à segurança nacional serão estudadas e coordenadas pelo Conselho Superior de Segurança Nacional e pelos órgãos especiais criados para atender às necessidades da mobilização.

$\S 1^{\circ}$ - O Conselho Superior de Segurança Nacional será presidido pelo Presidente da República e dele farão parte os Ministros de Estado, o Chefe do Estado-Maior do Exército e o Chefe do Estado-Maior da Armada.

Art. 162 - As forças armadas são instituições nacionais permanentes, e, dentro da lei, essencialmente obedientes aos seus superiores hierárquicos. Destinam-se a defender a Pátria e garantir os Poderes constitucionais, e, ordem e a lei.

Todas as mudanças pertinentes às Forças Armadas e à segurança nacional na Constituição de 1934 são representativas de diversas transformações que a década de 1930 trouxe ao mundo e, logo, ao Brasil. Forças partidárias figuravam naquele momento com uma representatividade nova, tal como o Partido Comunista e a Ação Integralista, movimento que congregava os adeptos do fascismo. Nas palavras de Nelson Werneck Sodré:

A fase, na dimensão mundial, era de ascensão fascista, forma com que o capitalismo em etapa imperialista respondia à consolidação do socialismo na União Soviética. (...) Em 1933, quando Hitler ascendeu ao poder na Alemanha e deu início ao nazismo, com o seu cortejo de torpezas, o sistema parecia dotado de todas as condições para corresponder à sua finalidade específica: fornecer a terapêutica eficaz, senão a única, capaz de barrar o avanço das conquistas democráticas. Que o modelo inspirasse burguesias do tipo da brasileira, submissas ao imperialismo pela sua debilidade, e colocadas ante a contradição de classe, reforçadas com o apoio do latifúndio para a tarefa de liquidação das liberdades, não é de surpreender. ${ }^{27}$

\footnotetext{
${ }^{27}$ SODRÉ, Nelson Werneck. Op. cit., p. 254.
} 
Em 1934, Getúlio Vargas foi escolhido, pela Constituinte, o Presidente da República trazendo com ele o marco da ascensão do movimento popular e democrático que se definiu em grandes greves. Surgia, em 1935, a Aliança Nacional Libertadora (ANL), movimento marcadamente antifascista que conseguiu congregar diversas forças democráticas e realizar diversas manifestações com amplo apoio popular. Seu chefe de honra era Luís Carlos Prestes, membro do PCB que, nesse momento, encontrava-se na ilegalidade. Evidente que sua influência também atingiu a área militar, repleta de resquícios do tenentismo, tornando-se extremamente perigosa para todos que defendiam uma ditadura no Brasil. A solução encontrada foi incentivar milícias integralistas para que disputassem também influências militares e, logicamente, fechar a ANL, a partir de medidas de exceção promulgadas pelo Congresso, sob o conhecido pretexto de que o movimento era financiado por Moscou. Luís Carlos Prestes esclarece a composição do movimento:

\begin{abstract}
É certo que, em 1935, os comunistas já constituíam a força de vanguarda, esclarecedora e mobilizadora das grandes massas populares. A insurreição de 1935 não foi, porém, um movimento exclusivamente comunista, nem pretendiam os insurretos de 35 instaurar em nosso país a ditadura do proletariado nem, muito menos, um governo comunista, como afirma a reação. A correlação de forças era outra, bem diferente da exposta pelos reacionários e agora perfilhada pelo Sr. Afonso Arinos. De um lado, estavam os patriotas e democratas e, de outro, os integralistas e os que foram por eles enganados juntamente com todos os reacionários e agentes do imperialismo. ${ }^{28}$
\end{abstract}

Foi nesse clima de mobilização social e radicalização ideológica que a Lei de Segurança Nacional ${ }^{29}$ foi publicada, em 4 de abril de 1935, como uma forma de reação política e jurídica do governo. A primeira vez que a lei foi usada foi justamente para fechar a ANL, em 11 de julho de 1935. O comunismo, patrocinado ou não por Moscou, já era a grande a preocupação do governo, assim como na Ditadura Militar (1964-1985), mas logo se tornaria seu inimigo número um. A Lei de Segurança Nacional provocou amplo debate e discussões intensas. O grupo parlamentar "Pró Liberdades Populares" chegou a pedir ao governo que

\footnotetext{
${ }^{28}$ Depoimento de Luís Carlos Prestes. Apud: SODRÉ, Nelson Werneck. A História Militar do Brasil, p. 255-256.

${ }^{29}$ Lei no 38 de 4 de abril de 1935.
} 
fosse também fechada a Ação Integralista Brasileira para que não houvesse nenhuma violação ao princípio da igualdade ${ }^{30}$.

A Lei de Segurança Nacional define os crimes "contra a ordem política e social” e prevê a Justiça Federal como o foro competente para julgamento desses crimes, com direito a recurso. Não há previsão de qualquer tribunal especial e não cita a Justiça Militar para julgar qualquer dos crimes previstos, sendo, no entanto, extremamente rígida nos crimes que envolvessem conspirações e movimentos militares. É uma lei principalmente contrária aos sindicatos, às greves e às organizações políticas. A expressão segurança nacional não é citada no texto da lei.

O "perigo vermelho" iria adquirir contornos cada vez mais nítidos, principalmente, após os levantes de Natal, Recife e Rio de Janeiro, em novembro de 1935. Fechada a ANL, muitos que dela participavam resolveram se afastar, mas aqueles que ficaram apostaram na alternativa insurrecional e a colocaram em prática com os levantes, compostos, especialmente, de militares. Em muitos aspectos, os levantes foram semelhantes às revoluções tenentistas da década de 1920, mas distingue-se não somente pelo conteúdo, como também pela intervenção da Internacional Comunista, que enviou ao Brasil diversos militantes, tal como Harry Berger e Victor Allen Barron. No Rio de Janeiro, os revoltosos obtiveram a adesão de grande parte da tropa do Terceiro Regimento de Infantaria na Praia Vermelha, mas, quando saíram para a rua, foram barrados pelas tropas do General Dutra. O movimento, chamado de Intentona Comunista, foi severamente abafado e reprimido pelo governo e pelas Forças Armadas, dando início a uma luta desenfreada contra o comunismo, agora, "o inimigo mais perigoso da civilização cristã”, ${ }^{31}$, com prioridade inédita para ser combatido.

Ainda no decorrer da revolta, foi pedido pelo governo ao Congresso o Estado de Sítio que foi concedido, embora, logo depois, tenha sido transformado

\footnotetext{
${ }^{30}$ FILHO, João Café. Do sindicato ao Catete, p.85. Rio de Janeiro: José Olympio, 1966. 320 p.

${ }^{31}$ Discurso de Getúlio Vargas. Apud: FAUSTO, Boris. Getúlio Vargas, p. 75. São Paulo: Companhia das Letras, 2006. 233 p.
} 
em Estado de Guerra pela Emenda Constitucional n ${ }^{0}$ 1, durando sem cessar até julho de 1937.

A Constituição de 1934, no art. 175, previa que o "Poder Legislativo, na iminência de agressão estrangeira, ou na emergência de insurreição armada, poderá autorizar o Presidente da República a declarar em estado de sítio qualquer parte do território nacional”. O prazo máximo para a vigência do Estado de Sitio era de noventa dias, podendo ser prorrogado, apenas uma vez, por igual prazo (art.175, 1). As medidas de exceção admitidas durante o Estado de Sítio estão previstas exaustivamente no art. 175, 2. O Estado de Guerra, previsto no art. 161, implicaria “a suspensão das garantias constitucionais que possam prejudicar direta ou indiretamente a segurança nacional."

Dessa forma, o Estado de Sítio foi, inicialmente, concedido pelo Congresso por trinta dias, abrangendo todo o território nacional. Posteriormente, foi prorrogado por mais noventa dias. O próximo passo foi a Emenda Constitucional $n^{0} 1$ :

\begin{abstract}
A Câmara dos Deputados, com a colaboração do Senado Federal, poderá autorizar o Presidente da Republica a declarar a comoção intestina grave, com finalidades subversivas das instituições políticas e sociais, equiparada ao estado de guerra, em qualquer parte do território nacional, observando-se o disposto no art. 175, n. $1, \S \S 7^{\circ}$, 12 e 13, e devendo o decreto de declaração da equiparação indicar as garantias constitucionais que não ficarão suspensas. (grifos nossos)
\end{abstract}

Com o Estado de Sítio inúmeras pessoas foram presas indiscriminadamente, muitas não eram comunistas, mas apenas faziam oposição ao regime vigente. Foram criadas a Comissão Especial de Combate ao Extremismo, que agiu no âmbito militar, e a Comissão Nacional de Repressão ao Comunismo, no âmbito civil, cujo presidente era o Deputado Adalberto Correia. No depoimento de Graciliano Ramos:

O levante do $3^{\circ}$ Regimento e a revolução de Natal havia desencadeado uma perseguição feroz. Tudo se desarticulava, sombrio pessimismo anuviava as almas, tínhamos a impressão de viver numa bárbara colônia alemã. (...) O congresso apavorava-se, largava bambo as leis de arrocho e vivíamos de fato numa ditadura sem freio. Esmorecida a resistência, dissolvidos os últimos comícios, mortos ou torturados operários e pequenoburgueses comprometidos, escritores e jornalistas a desdizer-se, a gaguejar, todas as 
poltronices a inclinar-se para a direita, quase nada poderíamos fazer perdidos na multidão de carneiros. ${ }^{32}$

Em dezembro de 1935, o governo conseguiu tornar a Lei de Segurança Nacional mais rígida, porque ela, "tal como saiu, podada, do Legislativo, não permitia manter uma ação eficiente.” ${ }^{33}$ Tornou mais fácil a demissão de funcionários públicos civis e militares quando filiados a "partido, centro, agremiação ou junta de existência proibida” ${ }^{34}$. Foram promulgadas também mais duas Emendas Constitucionais. A Emenda ${ }^{\circ} 2$ permitia que o Executivo cassasse patente e posto dos militares, e a Emenda $n^{0} 3$ permitia que o Executivo exonerasse funcionários civis, ou seja, que fossem demitidos sem qualquer processo.

As ações repressivas tornam-se então cada vez mais intensas após a Intentona de 1935. O comunismo passa a ser não apenas uma ameaça real ao Exército, mas também uma arma poderosa capaz de criar um clima de solidariedade interna ${ }^{35}$. O Exército ainda precisava solucionar as questões de hierarquia e disciplina dentro da organização, assim como definir o seu próprio papel dentro da sociedade. As atividades de cunho ideológico não eram desconhecidas dentro da organização militar, embora não se acreditava ser possível uma revolta armada de influência comunista. A Intentona gerou uma maior aproximação entre os chefes militares e a percepção de que um inimigo comum poderia tornar o Exército mais coeso, mais hierarquizado, mais homogêneo.

Segundo o ex-tenente Arthur da Costa e Silva:

Lembrei 1930 quando um político hábil soube lançar tenentes por toda a parte e desagregou o Exército, cujo comando só foi retomado em 1935, quando os efeitos da Intentona Comunista permitiram ao General Eurico Gaspar Dutra reassumir o controle do Exército e, conseqüentemente, das Forças Armadas, restabelecendo a disciplina e a hierarquia. Desses ensinamentos precisávamos extrair uma lição: era absolutamente

\footnotetext{
${ }^{32}$ RAMOS, Graciliano. Memórias do Cárcere, p. 25. $1^{\circ}$ volume. $4^{a}$ Ed. São Paulo: Martins, 1960. 358 p.

${ }^{33}$ Carta de Vargas a Aranha, 14 de dezembro de 1935. Apud: SILVA, Hélio. 1937 - Todos os golpes se parecem, p.106. Rio de Janeiro: Civilização Brasileira, 1970. 618 p.

${ }^{34}$ Art. $1^{\circ}$ da Lei 136/1935.

${ }^{35}$ COELHO, Edmundo Campos. Op. cit., p. 115.
} 
necessário que, desde o primeiro instante, as Forças Armadas se apresentassem como um bloco. ${ }^{36}$

\subsection{A Carta de 1937}

O comunismo, após a Intentona de 1935, passou a ser o inimigo público número um, violentamente combatido pela polícia, pela cúpula militar, pelo governo. Apesar de toda a propaganda criada em torno dos comunistas, era preciso que ocorresse um evento capaz de estimular e legitimar definitivamente uma ditadura, apagando de vez qualquer liberdade individual e coletiva. Esse evento foi chamado de Plano Cohen, um documento usado para treinamento pelos integralistas. Seu autor foi o Capitão Olímpio Mourão Filho. O Presidente do Supremo Tribunal Militar, General Álvaro Mariante, ficou bastante interessado no documento e, em 30 de setembro de 1937, a Casa Militar da Presidência da República publicou uma nota em todos os jornais anunciando a descoberta de um tenebroso plano comunista. Não houve, então, qualquer dificuldade para que, no dia 10 de novembro de 1937, um esquadrão de polícia fechasse as duas casas do Congresso dando início ao Estado Novo.

O Estado Novo foi uma fase extremamente importante para o Exército e suas conseqüências foram duradouras. Não apenas a Intentona foi um fator de coesão na organização militar, mas também propiciou a construção de uma doutrina capaz de definir o papel do Exército na sociedade brasileira. O responsável por desenvolvê-la foi o General Góes Monteiro. Segundo o General $^{37}$, a maior característica da história militar foi, além das rivalidades dentro da elite militar e da indisciplina dos baixos escalões, o fato de que o Exército nada mais fez do que servir às facções civis. As causas desses problemas seriam a repulsa que a sociedade civil sentia pelos militares e o liberalismo. A solução seria fortalecer o Exército que, juntamente com a

\footnotetext{
${ }^{36}$ Ibid. p. 119.

${ }^{37}$ Para os depoimentos de Góes Monteiro: COELHO, Edmundo Campos. Op. cit., p. 98-118.
} 
Marinha, seriam os grandes responsáveis pela "segurança interna e externa da Nação”. Nas palavras do General:

(...) O Exército e a Marinha são, por conseguinte, os responsáveis máximos pela segurança interna e externa da Nação, precisando para este fim serem evidentemente tão fortes quanto possível, de modo que nenhum outro elemento antagônico à sua finalidade possa ameaçar os fundamentos da Pátria. Nestas condições, as forças militares têm de ser, naturalmente, forças construtoras, apoiando, governos fortes, capazes de movimentar e dar nova estrutura à existência nacional, porque só com a força é que se pode construir , visto que com fraqueza só se constroem lágrimas (...) ${ }^{38}$

A segurança nacional, nesse contexto, está associada a um projeto de disciplina da sociedade civil. Segundo o General:

(...) o meio mais racional de estabelecer, em bases sólidas, a segurança nacional, com o fim, sobretudo, de disciplinar o povo e obter o máximo de rendimento em todos os ramos de atividade pública, é justamente adotar os princípios de organização militar, contanto que seja isenta do espírito militarista (...) ${ }^{39}$

Em relação ao liberalismo, Góes Monteiro se posiciona:

(...) esse regime abstrato, que nos deve reger até a morte, porque assim convém ao bizantino e inviolável espírito do liberalismo, fonte de todos os males sociais e pátrios, forjado para que a todos se permita a liberdade de se encarniçarem na prática do mal contra o bem, aumentando o babelismo e as complicações do problema da organização nacional. ${ }^{40}$

Dessa forma, o Estado Novo possibilitou a organização das Forças Armadas com ênfase na disciplina e no aparelhamento da corporação. Nesse momento, as Forças Armadas se proclamam modernizadoras, reformadoras, com o desenvolvimento envolto pela segurança nacional.

A Carta de 1937, redigida pelo jurista Francisco Campos, não cita o Tribunal de Segurança Nacional. O TSN foi criado com o objetivo de punir os comunistas responsáveis pela Intentona, mas durou até o ano de 1945, funcionando como um verdadeiro tribunal de exceção. A Justiça Militar foi definida da seguinte forma:

\footnotetext{
${ }^{38}$ Ibid. p. 104

${ }^{39}$ Ibid. p. 105

${ }^{40}$ Ibid. p. 101-102
} 
Art 111 - Os militares e as pessoas a eles assemelhadas terão foro especial nos delitos militares. Esse foro poderá estender-se aos civis, nos casos definidos em lei, para os crimes contra a segurança externa do Pais ou contra as instituições militares.

Art 112 - São órgãos da Justiça Militar o Supremo Tribunal Militar e os Tribunais e Juízes inferiores, criados em lei.

A Carta dedica um capítulo à Segurança Nacional e um capítulo à Defesa do Estado, transparecendo uma série de ameaças possíveis para o Brasil. O capítulo referente à Segurança Nacional trata, principalmente, das Forças Armadas e do Conselho de Segurança Nacional. Cabe ressaltar que própria definição das Forças Armadas presente no art. 161 encontra-se dentro do capítulo dedicado à Segurança Nacional. O capítulo que trata da Defesa do Estado referese ao Estado de Guerra e ao Estado de Emergência.

Segundo Mário Pessoa, pela Carta de 1937, segurança nacional equivale à defesa externa e defesa do Estado equivale à segurança interna. Essa distinção, no entanto, não excluiria a relação que uma estabelece com a outra. $^{41}$

Transcrevemos abaixo os artigos que consideramos mais importantes:

Art. 161 - As forças armadas são instituições nacionais permanentes, organizadas sobre a base da disciplina hierárquica e da fiel obediência à autoridade do Presidente da República.

Art. 164 - Todos os brasileiros são obrigados, na forma da lei, ao serviço militar e a outros encargos necessários à defesa da pátria, nos termos e sob as penas da lei.

Parágrafo único - Nenhum brasileiro poderá exercer função pública, uma vez provado não haver cumprido as obrigações e os encargos que lhe incumbem para com a segurança nacional.

Art. 166 - Em caso de ameaça externa ou iminência de perturbações internas ou existências de concerto, plano ou conspiração, tendente a perturbar a paz pública ou pôr em perigo a estrutura das instituições, a segurança do Estado ou dos cidadãos, poderá o Presidente da República declarar em todo o território do País, ou na porção do território particularmente ameaçado, o estado de emergência.

Desde que se torne necessário o emprego das forças armadas para a defesa do Estado, o Presidente da República declarará em todo o território nacional ou em parte dele, o estado de guerra.

\footnotetext{
${ }^{41}$ PESSOA, Mário. O Direito da Segurança Nacional, p. 115. R: Biblioteca do Exército; São Paulo: Revista dos Tribunais, 1971. 356 p.
} 
Parágrafo único - Para nenhum desses atos será necessária a autorização do Parlamento nacional, nem este poderá suspender o estado de emergência ou o estado de guerra declarado pelo Presidente da República.

Art. 172 - Os crimes cometidos contra a segurança do Estado e a estrutura das instituições serão sujeitos a justiça e processos especiais que a lei prescreverá. (todos os grifos são nossos)

Alguns pontos destes artigos constitucionais merecem destaque. Embora, formalmente, as Forças Armadas estivessem submetidas ao poder do Presidente, evidente que se analisarmos a sua participação no Estado Novo, tal previsão não se concretizou. É notório, na maioria da literatura que se debruça sobre a época, que o Estado Novo foi um regime apoiado pelos militares. Os militares teriam instaurado o Estado Novo para posteriormente o cancelarem. ${ }^{42}$ Getúlio Vargas, em seu diário, relata:

A campanha de boletins infamantes contra mim é muito grande. Confesso que estou apreensivo com estas conspirações e a falta de coesão entre os elementos que apóiam o governo. Estou à mercê do Exército, sem força que o controle e sem autoridade pessoal e efetiva contra ele. Estou só e calado para não demonstrar apreensão. As próprias pessoas da minha família passeando na maior despreocupação. O inimigo esparso e difuso procura diluir as resistências. Veremos o que está para acontecer. ${ }^{43}$

Os artigos supracitados revelam uma preocupação intensa com a segurança nacional, defesa da Pátria e segurança do Estado, prevendo, inclusive, justiça e processo especiais para aqueles que contra elas se insurgirem. As idéias lançadas nessa época, principalmente pelo General Góes Monteiro, revelam semelhanças com as concepções de organização militar e segurança surgidas na Escola Superior de Guerra. As percepções de que o Exército é responsável pela segurança interna, que o comunismo é o grande inimigo a ser combatido, e que a democracia não pode sustentar a insegurança causada por este inimigo estão presentes em ambos os momentos. Não há, contudo, o mesmo aprimoramento conceitual que se verificou nas décadas de 1950 e 1960.

\footnotetext{
${ }^{42}$ COELHO, Edmundo Campos. Op. cit., p. 111.

${ }^{43}$ VARGAS, Getúlio. Diário, p. 226. Volume II. São Paulo: Siciliano; Rio de Janeiro: Fundação Getúlio Vargas, 1995. $682 \mathrm{p}$.
} 
Evidente que nas décadas de 1930 e 1940 não coube apenas ao Exército zelar pela segurança interna ou pela defesa nacional. O Estado foi aparelhado para isso com leis, regras e uma instituição singular. As Forças Armadas ainda eram pouco aptas politicamente e ideologicamente para enfrentar situações emergenciais. ${ }^{44}$

Em 1944, com a guerra chegando ao fim, os sintomas de derrocada do Estado Novo começavam a se anunciar. O movimento pela anistia dos presos políticos levou multidões à rua. No dia 18 de abril de 1945, a anistia era decretada, libertando 563 presos políticos. ${ }^{45} \mathrm{~A}$ liberdade de imprensa foi alcançada, e novos rumos se abriam para o Brasil aos passos do novo clima mundial.

No dia 29 de outubro de 1945, Vargas era deposto por um golpe militar de cúpula que envolvia, principalmente, o General Dutra, o General Góis Monteiro e o Brigadeiro Eduardo Gomes. No dia 2 de dezembro, as eleições deram vitória ao General Eurico Gaspar Dutra, Ministro de Guerra durante o Estado Novo.

\subsection{A Constituição de 1946}

A Constituição de 1946, promulgada durante o governo Dutra, não possui capítulos dedicados exclusivamente à Segurança Nacional ou à Defesa do Estado. Há um capítulo dedicado às Forças Armadas que, entre outros aspectos, trata da sua definição, além de tratar do Conselho de Segurança Nacional. Transcrevemos abaixo os artigos que consideramos mais relevantes:

Art. 176 - As forças armadas, constituídas essencialmente pelo Exército, Marinha e Aeronáutica, são instituições nacionais permanentes, organizadas com base na hierarquia e na disciplina, sob a autoridade suprema do Presidente da República e dentro dos limites da lei.

Art. 177 - Destinam-se as forças armadas a defender a Pátria e a garantir os poderes constitucionais, a lei e a ordem

\footnotetext{
${ }^{44}$ D'ARAUJO, Maria Celina. Op. cit.

${ }^{45}$ Decreto - lei no 7474 de 18 de abril de 1945.
} 
Art. 179 - Os problemas relativos à defesa do País serão estudados pelo Conselho de Segurança Nacional e pelos órgãos especiais das forças armadas, incumbidos, de prepará-las para a mobilização e as operações militares.

$\S 1^{\circ}$ - O Conselho de Segurança Nacional será dirigido pelo Presidente da República, e dele participarão, no caráter de membros efetivos, os Ministros de Estado e os Chefes de Estado-Maior que a lei determinar. Nos impedimentos, indicará o Presidente da República o seu substituto.

$\S 2^{\circ}$ - A lei regulará a organização, a competência e o funcionamento do Conselho de Segurança Nacional.

O governo do General Dutra foi marcado por uma duríssima repressão. Além de prisões e espancamentos, era necessário reduzir o poder de resistência do Legislativo. Em 1947, o governo, por meio da Justiça Eleitoral, conseguiu o fechamento do Partido Comunista e, em 1948, por meio do Poder Legislativo, a cassação dos mandatos dos representantes deste partido. Mais uma vez, o Partido Comunista encontrava-se na clandestinidade. Mais uma vez, a violência e a arbitrariedade tornavam-se recorrentes no cotidiano do País:

Todos se recordam da chacina da Praça Floriano, naquele ano, por ocasião da qual o povo foi agredido, na presença de três generais, ao pé da estátua do Marechal de Ferro, quando o General Carnaúba, nosso presidente em exercício, saudava a memória de Floriano, após o encerramento da sessão inaugural do Congresso. ${ }^{46}$

Sobre o fechamento do Partido Comunista e a cassação dos mandatos dos seus representantes, Sinval Palmeira esclarece:

(...) Cancelado o registro do Partido Comunista do Brasil, não poderia a reação se deter em meio ao despenhadeiro para a ditadura, em que já vivemos tantos anos, por desgraça nossa e para vexame da consciência jurídica nacional, particularmente desse Tribunal excelso, tantas vezes por ela atingida em sua majestade. Assim, depois da tentativa frustrada perante o próprio TSE, surgiu o projeto Ivo d'Aquino, visando cassar os mandatos dos comunistas eleitos pelo povo, livremente, às diversas assembléias do país. (...) Expulsar Prestes do Senado, com o voto de Filinto Muller, implicado em espionagem pelo Eixo, como foi denunciado do Supremo Tribunal Militar pelo saudoso General Manoel Rabelo! ${ }^{47}$

\footnotetext{
${ }^{46}$ SODRÉ, Nelson Werneck. Op. cit., p. 292.

${ }^{47}$ Sinval Palmeira em defesa do mandato de Prestes. Apud: SODRÉ, Nelson Werneck. A História Militar do Brasil, p. 293.
} 
A Lei de Segurança Nacional que vigorava até então era o DL 431/1938 ${ }^{48}$. Em 1947, o Ministério da Justiça encaminha ao Congresso o projeto do que viria a ser a nova Lei de Segurança Nacional. Assim como a lei de 1935, ambas foram debatidas no Congresso. A diferença é que a nova Lei de Segurança Nacional somou ao todo quase seis anos de debate, sendo aprovada em $1953^{49}$. Os militares acharam a lei muito branda, a oposição, muito rígida. A Lei 1802/1953 não reconhecia a categoria crime político e estipulava que os delitos contra o Estado e a ordem política e social seriam julgados na Justiça comum. Apenas os crimes contra a segurança externa estariam na jurisdição da Justiça Militar.

Entre o início das discussões da nova Lei de Segurança Nacional e a sua aprovação, em 1953, um novo empreendimento militar foi criado no Brasil: a Escola Superior de Guerra. Com a sua instauração, em 1949, uma nova e importante fase começa a ser trilhada no País, uma fase de aprimoramento conceitual da segurança nacional que será colocada em prática, definitivamente, em 1964.

\footnotetext{
${ }^{48}$ Decreto- lei no 431 de 18 de maio de 1938. Define crimes contra a personalidade internacional, a estrutura e a segurança do Estado e contra a ordem social.

${ }^{49}$ Lei n $^{\circ} 1802$ de 5 de janeiro de 1953. Define os crimes contra o Estado e a Ordem Política e Social, e dá outras providências.
} 


\title{
2. Os militares e a Escola Superior de Guerra: presságios de um golpe
}

\begin{abstract}
"Havia, enfim, a Escola Superior de Guerra. Falava-se muito pouco nela. Preparava-se discretamente. Conspirava.” (Joseph Comblin - A ideologia da segurança nacional)
\end{abstract}

\subsection{A criação da Escola Superior de Guerra}

A Escola Superior de Guerra foi criada oficialmente pela Lei $\mathrm{n}^{\circ} 785$ de 20 de agosto de 1949. Da sua fundação participaram oficiais que, durante a $2^{\mathrm{a}}$ Guerra Mundial, foram enviados à Itália. O Presidente Getúlio Vargas rompeu as relações com o Eixo em janeiro de 1942, e até a tomada de Berlim pelas forças Aliadas, em maio de 1945, o Brasil enviaria à guerra 25 mil homens. ${ }^{50}$

"Este exército não vai à batalha", exclamava o General Góis Monteiro ${ }^{51}$. Talvez, ele tivesse sua parcela de razão. O Exército brasileiro funcionou mal na guerra. Elio Gaspari relata que a tropa estava malvestida e mal calçada. ${ }^{52} \mathrm{O}$ verde dos seus uniformes se confundia com a cor do uniforme alemão. Após desembarcar em Nápoles, desarmada, foi confundida com prisioneiros, e vaiada. Num regimento do Rio Grande do Sul, o comandante selecionou para a Força Expedicionária os soldados com mau comportamento. Não tinham blindados, artilharia antiaérea ou munições em geral. O General Dutra chegou a sustentar que a mobilização de suas tropas era tarefa quase impossível. ${ }^{53}$

Durante a guerra, a tropa brasileira lutou ao lado dos americanos, comandados pelo General Mark Clark. Com o término da guerra e a volta ao Brasil, os oficiais trouxeram com eles uma conclusão inevitável: o Exército americano era superior, e funcionava. Mais tarde, após a guerra chegar ao fim, a realidade da Guerra Fria aproximaria ainda mais os dois países, e juntos

\footnotetext{
${ }^{50}$ GASPARI, Elio. A Ditadura Derrotada, p. 43.

${ }^{51}$ Ibid. p. 44

${ }^{52}$ Ibid. p. 118

${ }^{53}$ Ibid. p. 44
} 
voltariam a combater um inimigo comum: o comunismo, suposto instrumento utilizado pela URSS para expandir-se mundialmente. Segundo René Dreifuss:

Um pequeno número de oficiais dentro das Forças Armadas (...), após a $2^{\mathrm{a}}$ Guerra Mundial, havia se tornado um grupo modernizante-conservador (...). Algumas das figuras de destaque desse grupo podem ser traçadas historicamente a partir de sua experiência ideológica e militar comum durante a campanha na Itália, experiência que mais tarde foi reforçada pela participação em cursos de instrução e treinamento nos EUA. Essa experiência comum estendeu-se através da afiliação posterior daqueles oficiais a certos partidos políticos, principalmente a UDN - União Democrática Nacional- e em menor escala ao PDC - Partido Democrata Cristão - assim como pela sua organização num reduto político e ideológico, a Escola Superior de Guerra - ESG da qual eram co-fundadores. ${ }^{54}$

O então tenente-coronel Castello Branco, que seria o primeiro Presidente da ditadura militar, estabeleceu fortes laços de amizade com o militar Vernon A. Walters. Essa relação seria fundamental para que, em 1964, Walters obtivesse informações dos militares brasileiros sobre o golpe. ${ }^{55}$

Duas expressões marcavam e influenciavam o mundo naquele momento: Guerra Fria e Cortina de Ferro. A primeira foi cunhada por um jornalista americano, Walter Lippmann, ao dar título a uma coletânea de artigos escritos em 1947. Ele utilizou uma expressão francesa usada, em 1939, para denominar a política de intimidação de Hitler na Europa, "la guerre froide." ${ }^{56}$ A segunda foi criada pelo ex-primeiro-ministro inglês, Winston Churchill, durante um discurso nos EUA:

De Stettin, no Báltico, a Trieste no Adriático, uma cortina de ferro caiu sobre o Continente. Atrás dessa linha, todas as capitais dos velhos Estados da Europa Central, Varsóvia, Berlim, Praga, Viena, Budapeste, Belgrado, Bucareste e Sofia, todas essas famosas cidades, bem como as populações que as circundam, estão submetidas não só à influência soviética, mas a um grande e crescente controle por Moscou. ${ }^{57}$

Embora, essas expressões tenham parecido extremamente sedutoras para o conservadorismo brasileiro, entendemos que o Brasil lutou contra a Cortina de

\footnotetext{
${ }^{54}$ DREIFUSS, Réne Armand. 1964: a Conquista do Estado, p. 77-78. 2ª Ed. Petrópolis: Vozes, 1981. $814 \mathrm{p}$.

${ }^{55}$ FICO, Carlos. O grande irmão - Da operação Brother Sam aos anos de chumbo, p. 20. $2^{\mathrm{a}}$ ed. Rio de Janeiro: Civilização Brasileira, 2008. 334 p.

${ }^{56}$ GASPARI, Elio. Op. cit., p. 123.

${ }^{57}$ Ibid. p, 124
} 
Ferro antes que ela tivesse um nome, e combateu na Guerra Fria antes mesmo dela começar. Cabe ressaltar que o Brasil foi o primeiro país do mundo ocidental a romper relações com Moscou. As relações diplomáticas com Moscou duraram trinta meses, até outubro de 1947, quando foram rompidas. A legalidade do Partido Comunista também não vingou, como já citamos, durando apenas dezoito meses. Em junho de 1946, Góes Monteiro declarava que "a primeira bomba atômica foi jogada em Hiroshima e a segunda em Nagasaki, a terceira e a quarta no atol de Bikini, mas a quinta, a sexta, sétima e oitava podem muito bem cair na Rússia.” 58

Antes mesmo da criação da Escola Superior de Guerra, o seu comandante, General Oswaldo Cordeiro de Farias, alertava:

Precisamos preparar-nos para a eventualidade da terceira guerra mundial, o que é uma conseqüência do panorama internacional, uma política de autodefesa, um imperativo de nossa soberania e do nosso espírito de sobrevivência. Viver despreocupado deste problema, num mundo que não se entende, é ter mentalidade suicida. ${ }^{59}$

A origem remota da Escola Superior de Guerra é relacionada a um curso de Alto Comando criado, em 1942, pela Lei do Ensino Militar, e destinava-se apenas a generais e coronéis do Exército. ${ }^{60} \mathrm{~A}$ finalidade do curso era o estudo das questões referentes ao emprego das Grandes Unidades estratégicas e à direção da guerra, além das operações de ordem técnica e do serviço, relacionadas com o emprego dessas Grandes Unidades. Havia também um sincero interesse da cúpula militar para que os oficiais superiores se aprimorassem intelectualmente. Esse curso hibernou até 1948 quando o dec. 25.705/1948 determinou que o Estado- Maior Geral deveria organizar uma "Escola Superior de Guerra” para ministrar um "Curso de Alto Comando" aos oficias das três forças. ${ }^{61}$ Em janeiro de 1949, Cordeiro de Farias já era o presidente de uma comissão de oficiais responsáveis por elaborar o anteprojeto

\footnotetext{
${ }^{58}$ Ibid. p, 127

${ }^{59}$ Ibid. p, 123

${ }^{60}$ ARRUDA, Antônio de. A Escola Superior de Guerra- a História de sua Doutrina, p. XXI. 2aed. São Paulo: GRD; Brasília: Instituto Nacional do Livro, 1983. 303 p.

${ }^{61}$ Art. $1^{\circ}$ e $2^{\circ}$ do dec. 25705/1948
} 
de regulamento da instituição. No dia 11 de fevereiro de 1949, ele foi nomeado o primeiro comandante da ESG. ${ }^{62}$

A influência norte-americana na guerra marcou os oficiais brasileiros. No contexto externo, os EUA despontavam como potência mundial, ao mesmo tempo em que se contrapunham explicitamente à União Soviética, iniciando o período chamado de Guerra Fria, como citamos anteriormente. Joseph Comblin afirma que os oficias voltaram da guerra já com o intuito de copiarem o National War College americano. ${ }^{63}$ Uma missão americana foi encarregada de auxiliar os militares brasileiros na construção da ESG, e a orientará por doze anos consecutivos. Nas palavras de Antonio de Arruda:

Foi a viagem que, em 1948, o General César Obino, então chefe do Estado-Maior Geral (depois EMFA), fez aos Estados Unidos. Diz a tradição oral da Escola que, visitando o National War College, o General Obino dissera que no Brasil se estava também implantando uma Escola semelhante. E os americanos gentilmente ofereceram uma Missão Militar para apoiar a implantação da nossa Escola, o que foi aceito. (grifo nosso) 64

O primeiro documento oficial da ESG ressalta as diferenças entre a Escola brasileira e o National War College americano criado em 1946:

\begin{abstract}
Afasta-se a Escola Superior de Guerra de sua similar norte-americana. Esta agindo em um meio mais desenvolvido, em que o sistema educacional que formou as elites se encarregou de lhes inculcar um método de trabalho e de solução de problemas gerais já consagrados na vida nacional. (...) A Escola proposta no Brasil encontra ambiente: aqui é tão permanente o problema da preparação para a guerra: lutamos ainda para resolver o problema da vida nacional em tempo de paz; por outro lado, reconhecemos que nosso atraso é motivado, sobretudo, pelo defeito do sistema educacional, que habilita as elites com conhecimentos gerais, mas não com Armas com recursos para resolver os problemas da vida nacional. ${ }^{65}$
\end{abstract}

A Doutrina de Segurança Nacional manifestou-se nos Estados Unidos com ênfase na guerra total, na estratégia nuclear associada à moderna indústria

\footnotetext{
${ }^{62}$ PILATTI, Adriano. A influência norte-americana na criação da Escola Superior de Guerra e na formulação da Doutrina de Segurança Nacional e Desenvolvimento brasileiras, p. 9. Trabalho apresentado no curso de Mestrado da PUC-Rio. Novembro, 1985. 15 p.

${ }^{63}$ COMBLIN, Joseph. A ideologia da segurança nacional, p. 155. $3^{\mathrm{a}}$ Ed. Rio de Janeiro: Civilização Brasileira, 1980. $251 \mathrm{p}$.

${ }^{64}$ ARRUDA, Antonio de. Op. cit., p. XXI.

${ }^{65}$ MARKUN, Paulo; HAMILTON, Duda. 1961- Que as armas não falem, p. 149. São Paulo: Senac, 2001. $410 \mathrm{p}$.
} 
militar, na necessidade de desenvolvimento tecnológico. No Brasil, a segurança nacional é associada à subversão interna e à guerra revolucionária, a torturas e prisões.

Antonio de Arruda em seu livro A Escola Superior de Guerra expõe opiniões bastante interessantes, senão curiosas, sobre a Doutrina traçada na Escola. Ele chega a dizer que:

Por outro lado, a Doutrina da ESG se caracteriza ainda pelo seu humanismo. Em toda a colocação doutrinária da Escola, o homem é visto como o centro das preocupações. O que se busca especialmente é o Bem Comum, na concepção tomista que nutriu a cultura ocidental. ${ }^{66}$

A Lei 785/1949 cria a Escola Superior de Guerra que seria "um instituto de altos estudos, subordinado diretamente ao Chefe do Estado Maior das Forças Armadas e destinado a desenvolver e consolidar os conhecimentos necessários para o exercício das funções de direção e para o planejamento da segurança nacional" (art. $1^{\circ}$ ) e funcionaria como "centro permanente de estudos e pesquisas e ministrará os cursos que, nos termos do art. $4^{\circ}$, forem instituídos pelo Poder Executivo" (art. $2^{\circ}$ ). Poderiam ingressar na ESG “oficiais de comprovada experiência e aptidão, pertencentes às Forças Armadas, e civis de notável competência e atuação relevante na orientação e execução da política nacional” (art. $5^{\circ}$.

Em 1953, foi criado o primeiro curso da ESG, o Curso de Comando e Estado-Maior das Forças Armadas. O regulamento da ESG de 1973 aumentou a função inicial, estritamente ligada à segurança nacional, estendendo-a para a "formulação e planejamento da Política Nacional de Segurança e Desenvolvimento.” (grifo nosso) ${ }^{67}$

Os militares sempre estiveram associados à idéia de segurança, mesmo quando essa relação não estava explícita em textos normativos. O crescente ganho de poder político dos militares foi tornando essa relação mais íntima, mas

\footnotetext{
${ }^{66}$ ARRUDA, Antonio de. Op. cit., p. XXXI.

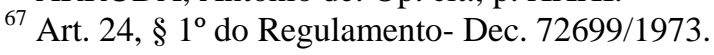


precisava também ser convincente para justificar qualquer intervenção política mais rígida das Forças Armadas.

A Doutrina de Segurança Nacional e Desenvolvimento foi usada para justificar a imposição de um sistema, ao mesmo tempo em que previa que o Estado seria capaz de legitimar-se através do desenvolvimento capitalista e da perseguição aos "inimigos internos", garantindo "a defesa da nação". A legitimação está, então, associada ao desenvolvimento econômico e à segurança interna.

Para tão complicada missão, “a Sorbonne reiúna”, forma como Darcy Ribeiro ${ }^{68}$ denominava a ESG, contou com o apoio incondicional do complexo IPES/IBAD criado em 1962. Juntos criariam projetos, desenvolveriam diretrizes e traçariam planos para a gestão do desenvolvimento capitalista ${ }^{69}$. Foram "uma verdadeira e eficiente burocracia paralela para o planejamento de um novo Estado." 70

O IPES/IBAD articulava os principais militares de direita com os setores predominantes das classes dominantes do País. Antes do golpe de 1964, o objetivo mais importante desse complexo foi criar uma rede de informações capaz de fornecer os dados considerados necessários para a centralização do Estado. Alguns oficiais trabalhavam paralelamente na ESG e no IPES, sob o comando do General Golbery do Couto e Silva. Antes da tomada de poder já possuíam dossiês de informações de mais de quatrocentos mil cidadãos brasileiros. $^{71}$

Entre 1950 e 1959, 483 militares fizeram algum curso na ESG. Dentre eles, dois chegaram à Presidência da República (Geisel e Castello Branco), 23 ao ministério e seis chefiaram o Exército. Passaram pela ESG, no mesmo período, 335 civis, mas apenas quatro chegaram ao ministério. Um deles foi Tancredo Neves. Affonso Henrique de Miranda Corrêa tenente-coronel, que comandou os calabouços da Delegacia Especial de Segurança Política e Social do Estado

\footnotetext{
${ }^{68}$ RIBEIRO, Darcy. 1962, Ano do Chute. In: Aos Trancos e Barrancos. 2aed. Rio de Janeiro: Guanabara, 1985. Páginas não declaradas.

${ }^{69}$ ALVES, Maria Helena Moreira. Op. cit., p. 25.

${ }^{70}$ Ibid. p, 25

${ }^{71}$ Ibid. p, 25.
} 
Novo, e que "estagiou" durante um ano na Gestapo, tornou-se o encarregado da administração da ESG. O coronel Antônio José Coelho dos Reis, que dirigiu toda a máquina de censura e propaganda do DIP, tornou-se o responsável pela Divisão de Assuntos Militares da ESG. ${ }^{72}$

Como ex-comandantes da ESG, podemos citar: Oswaldo Cordeiro de Farias (1949 a 1952), Juarez do Nascimento Fernandes Távora (1952 a 1954), Aurélio de Lyra Tavares (1966 a 1967), Augusto Fragoso (1967 a 1971), Lauro Alves Pinto (1971 a 1972), João Bina Machado (1972 a 1974) e Euclydes de Oliveira Figueiredo Filho (1983 a 1985). ${ }^{73}$

Entre estagiários, importantes colaboradores e membros permanentes da ESG, podemos destacar: Arthur Bernardes Alves de Souza, Augusto Hamann Rademaker Grunewald, Eduardo Hugo Frota, Newton Araújo de Oliveira e Cruz, Golbery do Couto e Silva, Ernesto Geisel, Hermes Rodrigues da Fonseca Filho, Adhemar de Barros Filho, Mário Pessoa de Oliveira, Humberto Castello Branco, César Obino, Roberto de Oliveira Campos, Arthur da Costa e Silva, Antonio Delfim Neto, Jarbas Passarinho, Mario Henrique Simonsen, Octávio Gouvêa de Bulhões, Emílio Garrastazu Médici e João Baptista de Oliveira Figueiredo. ${ }^{74}$

A idéia básica da Escola Superior de Guerra era a de que o Brasil poderia ser transformado numa potência mundial, caso alguns “obstáculos” fossem superados e eliminados. Esses obstáculos envolveriam basicamente os problemas “ideológicos” internos e o subdesenvolvimento econômico. Por isso, convencionou-se chamar a doutrina da ESG de Doutrina de Segurança Nacional e Desenvolvimento.

A forma pela qual os militares aderiram a essa Doutrina se deu, principalmente, pela chamada "missão saneadora" ${ }^{75}$. Esta missão consiste na necessidade de eliminar o comunismo, a "subversão", os “inimigos internos”. Era

\footnotetext{
${ }^{72}$ GASPARI, Elio. Op. cit., p. 122-128.

73 A lista com os nomes de todos os ex-comandantes da ESG está disponível em: http://www.esg.br/aesg/ex-comandantes/

${ }^{74}$ O nome de todos os estagiários da ESG está disponível em: http://www.adesg.org.br

${ }^{75}$ FICO, Carlos. 1968- o ano que terminou mal, p. 230-232. In: FICO, Carlos; ARAUJO, Maria Paula (Org.). 1968- 40 anos depois. História e Memória. Rio de Janeiro: 7 letras, 2009, p. 223-238.
} 
preciso uma grande "operação limpeza” capaz de prender, exilar, amedrontar qualquer pessoa julgada pelo regime como inimiga.

Essa dimensão "saneadora" incluía medidas efetivas de repressão, por isso o regime utilizava instrumentos que classificava de "revolucionários", tais como prender sem mandado judicial, torturar, censurar. Abrange também a espionagem, a polícia e os militares que exerciam funções policiais. Essas atividades eram normatizadas por diretrizes secretas, na esfera da legislação "revolucionária” ou excepcional, como analisaremos no próximo capítulo.

Essa concepção "saneadora”, que permeou a ditadura militar e, portanto, a mentalidade militar da época, possibilitou a ação dos militares nos "calabouços", nos "porões" da ditadura, sempre sancionada pelos oficiais-generais. Houve uma policialização das forças militares. A ditadura e a tortura não caminhavam separadas, uma compunha a outra num movimento de quase dependência recíproca. A face mais cruel da segurança nacional, nesse momento, foi justamente a introjeção de um modelo repressivo que em nada relacionava-se com a defesa da sociedade e o desenvolvimento do País. Era puro fruto de arbitrariedade e busca por postos de poder.

Ao lado da dimensão "saneadora" havia também a chamada dimensão "pedagógica” ${ }^{76}$. Ela consiste basicamente na idéia de que os brasileiros são “despreparados”, não sabem votar, são analfabetos, não têm conhecimento algum da realidade do País, não são educados, higiênicos. Logo, é preciso "prepará-los para a democracia", protegendo-os das "ideologias malévolas e deturpadas". Abrangia as atividades da censura moral e da propaganda política. Exemplo típico dessa concepção são as propagandas, criadas pela ditadura militar, que tinham como personagem central a figura do "Sujismundo", e cujo slogan era: "povo desenvolvido é povo limpo".

O desenvolvimento dos trabalhos da Escola Superior de Guerra pode ser dividido em quatro fases distintas. ${ }^{77}$ A primeira fase vai de 1949 a 1952. Nesse período, teve prioridade os estudos sobre Conjuntura, envolvendo temas como o

\footnotetext{
${ }^{76}$ Ibid. p, 231.

${ }^{77}$ ARRUDA, Antonio de. Op. cit, p. XXXV-XXXVI.
} 
petróleo, inflação, analfabetismo, conflito ideológico e infiltração comunista. Iniciou-se também o método de estudo em grupo. A segunda fase vai de 1953 a 1967. Foi em 1953 que começaram os estudos da Doutrina com ênfase no conceito de Segurança. Na terceira fase compreendida entre 1968 e 1973 a ênfase dos estudos recaiu no conceito de Desenvolvimento, tendência institucionalizada no Regulamento de 1973 que ampliou a função da ESG. Nessa fase foi estabelecida, segundo os teóricos da ESG, uma Doutrina de Política Nacional que envolvia Segurança e Desenvolvimento. A quarta e última fase teve início após 1973. Esse período caracteriza-se pela adoção do Manual Básico da ESG que teve por finalidade a consolidação e condensação de conceitos doutrinários e teóricos que não estariam ainda devidamente aprimorados.

Até a criação da ESG não havia uma compilação sobre segurança nacional no Brasil, embora ela já fosse uma grande preocupação no cenário interno, como demonstramos anteriormente. A ESG marca, portanto, uma ruptura nos estudos sobre segurança nacional e na sua relação com os militares. Não estamos afirmando que eles estavam sozinhos, já que a presença norte-americana há muito foi confirmada, além da presença de civis, claro, como muito bem esclarece René Dreifuss em sua obra 1964: a conquista do Estado. ${ }^{78} \mathrm{O}$ fato é que os militares foram os responsáveis por iniciarem a compilação da segurança nacional, sempre entrelaçada com repressão política e perseguições, ordem e desenvolvimento e combate ao comunismo. Foram os responsáveis também, quinze anos depois da criação da ESG, com o golpe de 1964, por colocarem todos os seus conceitos em prática. Nas palavras de Joseph Comblin:

O Brasil representa eminentemente a ideologia da segurança nacional, já que os protagonistas da ideologia puderam preparar sistematicamente, durante quinze anos, sua estratégia, e em seguida lhes foi possível pô-la em prática (desde 1964). Raramente uma geração terá mostrado tanta perseverança e continuidade, principalmente na América Latina. (...) De 1922 a 1964 esses homens perseguiram um objetivo e alcançaram-no. ${ }^{79}$

\footnotetext{
${ }^{78}$ DREIFUSS, Réne Armand. 1964: a Conquista do Estado.

${ }^{79}$ COMBLIN, Joseph. Op. cit., p. 151.
} 


\subsection{A Escola Superior de Guerra e a construção de uma doutrina}

Com a Guerra Fria, diversas mudanças ocorrem nas políticas de segurança e defesa. As guerras mudaram de conteúdo e de propósito. Não há apenas guerras convencionais, mas também guerras revolucionárias, totais, limitadas. O conceito de segurança se desdobra em segurança interna, externa, nacional. Na formulação de todos esses conceitos, verifica-se a presença de fatores políticos, econômicos, filosóficos e militares.

Para compreendermos como a Doutrina de Segurança Nacional e Desenvolvimento, assim chamada pelos teóricos da Escola Superior de Guerra, foi compilada e organizada, nos deteremos à sua principal fonte: o Manual Básico da $\mathrm{ESG}^{80}$. Evidente que pelo tamanho proposto para esse trabalho, não pretendemos analisar todos os conceitos tratados no Manual da ESG. Outros trabalhos já o fizeram, mas é importante ressaltar como certos conceitos até então usados aleatoriamente tomaram forma e conteúdo, e constituíram o que a Escola Superior de Guerra convencionou chamar de Doutrina.

Cabe, primeiramente, estabelecer a diferença entre Segurança e Defesa. Ao longo das Constituições, desde a Carta de 1824, como já explicitamos anteriormente, as palavras segurança e defesa foram utilizadas, mas sem que fosse possível compreender a diferença entre ambas. Daí a necessidade, segundo a ESG, de se distinguir esses conceitos, de modo que eles não se confundissem mais. A Defesa compreende uma ação específica e definida, um ato, enquanto a Segurança é uma condição ou estado que condiciona a execução da Defesa. A Segurança é, portanto, mais abrangente que a Defesa, já que esta como um ato está ligada a uma ameaça específica e caracterizada ${ }^{81}$. Segundo o General Lyra Tavares:

Segurança é um estado, ao passo que Defesa é um ato ou um conjunto de atos, diretamente ligado a determinado tipo de ameaça caracterizada e medida. A Defesa organiza-se para o fim especial de repelir um ataque previsto, ao passo que a Segurança,

\footnotetext{
${ }^{80}$ ESCOLA SUPERIOR DE GUERRA. Manual Básico. Rio de Janeiro: ESG, 1975. 573 p.

${ }^{81}$ Ibid. p. 232.
} 
no sentido que encaramos, é estabelecida como doutrina integral contra qualquer tipo de ameaça que ela própria, a Segurança, torna inoperante e desencoraja.

Para classificar Segurança, o Manual da ESG parte do negativo, elencando diversas razões que causam insegurança na Nação ${ }^{83}$. Elas podem ser de ordem material, cultural ou espiritual e moral. A razão de ordem material envolve a escassez de recursos, tal como as deficiências de industrialização e as dificuldades financeiras. A razão de ordem cultural trata de um aspecto curioso, embora previsível dentro da lógica do conservadorismo: a ignorância em diversos setores. Esta ignorância está vinculada à participação esclarecida do cidadão nos processos políticos e culturais do País. É nos motivos de ordem espiritual e moral que, segundo os teóricos da ESG, reside a maior razão de insegurança. O mundo estaria vivendo a "idade do protesto", ou seja, o confronto de gerações, de classes, de ideologias. Evidente que essa concepção remete-se diretamente ao confronto da Guerra Fria, em que o mundo é dividido em dois blocos, o americano e o soviético. O Manual registra, inclusive, que a Segurança de alguns Estados implica em insegurança para outros, já que envolveria busca de domínio, direto ou indireto, de outras Nações.

O conceito de Segurança envolve cinco aspectos: Segurança Individual, Segurança Comunitária, Segurança Coletiva, Segurança Específica e Segurança Nacional $^{84}$. A Segurança Individual envolve o campo de ação de homem, inclusive o espiritual. Para um homem se sentir seguro ele teria que resolver seus problemas endógenos, tais como a saúde, a educação e os meios de subsistência, e resolver também os problemas exógenos que seriam os direitos de propriedade, de locomoção e de proteção contra o crime em todas as suas formas. Em todos esses casos, caberia ao Estado, titular do Poder Nacional, prover a segurança à Nação. A Segurança Comunitária representa a necessidade do Estado de assegurar os aspectos que dão estabilidade às relações econômicas e sociais, tais como a propriedade, o capital e o trabalho. Estes aspectos estão situados no

\footnotetext{
${ }^{82}$ Conferência da ESG intitulada Segurança Nacional e problemas nacionais. Apud: ARRUDA, Antonio de. A Escola Superior de Guerra- a História de sua Doutrina, p. 6.

${ }^{83}$ ESCOLA SUPERIOR DE GUERRA. Op. cit., p. 231-232.

${ }^{84}$ Ibid. p, 232 - 236.
} 
âmbito da Ordem Pública dentro da qual está incluída, além da Segurança Comunitária, a Segurança Individual.

A Segurança Coletiva tem por finalidade explícita justificar o apoio norteamericano e a sua influência no Brasil, inclusive, nas opções e rumos econômicos travados no País. Essa concepção de Segurança trata da necessidade de apoio mútuo por um grupo de países que, juntos, eliminariam controvérsias e tomariam medidas nos vários campos de poder. Nas palavras do General Castello Branco:

\begin{abstract}
Nenhum país, seja no mundo ocidental, seja no soviético, poderá defender-se sozinho contra um ou outro dos centros dominantes de poder. A defesa tem que ser necessariamente associativa. Do mesmo modo, no campo econômico, o reconhecimento da interdependência é inevitável não só no comércio, mas sobretudo no tocante a investimentos. (...) No caso brasileiro, a política externa não pode esquecer que fizemos uma opção básica, da qual decorre uma fidelidade cultural e política ao sistema democrático ocidental. ${ }^{85}$
\end{abstract}

A Segurança Específica se preocupa com a Segurança nos quatro campos do Poder Nacional: o Poder Político, o Poder Econômico, o Poder Psicossocial e o Poder Militar. Percebendo as vulnerabilidades de cada um desses poderes, as suas capacidades de ação serão preservadas, de modo a aumentarem a participação no quadro da Segurança Nacional. Todos os aspectos da Segurança, acima tratados, são complementares ao conceito principal, Segurança Nacional. É em torno dela e para ela que tantas ramificações conceituais são criadas.

O General Augusto Fragoso ${ }^{86}$, em conferência proferida na ESG, informou que o primeiro documento sobre Poder Nacional, no Brasil, foi editado em 1947 pelo Ministério da Aeronáutica. Esse documento seria a tradução de um volume publicado em 1945, nos Estados Unidos, e que contém um curso ministrado na Universidade de Princeton a um grupo de oficiais da Aeronáutica. Para Roberto Campos: “Defino o Poder Nacional como sendo o poder de coerção que uma nação pode exercer sobre as outras, quer por métodos pacíficos, quer por métodos militares.” 87

\footnotetext{
${ }^{85}$ Ibid. p. 235.

${ }^{86}$ ARRUDA, Antonio. Op. cit., p. 19.

${ }^{87}$ Ibid. p. 22.
} 
O Poder Nacional é composto por quatro formas ou expressões: política, econômica, militar e psicossocial. Essas formas abrangem os diversos setores em que se dividem as atividades do Estado, em busca dos seus interesses. Transcrevemos, abaixo, o conceito oficial da Escola:

Poder Nacional é a expressão integrada dos meios de toda a ordem de que dispõe efetivamente a Nação, numa época considerada, para promover, sob a direção do Estado, no âmbito interno e externo, a consecução ou manutenção dos Objetivos Nacionais. ${ }^{88}$

Dessa forma, segundo o Manual, a aplicação deste Poder está voltada para o Desenvolvimento Nacional, já que o Brasil seria um País subdesenvolvido. Ao longo do tempo, com o Brasil saindo dessa posição economicamente desprivilegiada e emergindo no cenário dos países desenvolvidos, a segurança externa ocuparia um papel mais relevante. A ênfase na segurança interna seria um aspecto relacionado, portanto, com o subdesenvolvimento.

O Manual da ESG possui um capítulo dedicado as quatro formas de expressão do Poder Nacional: militar, econômico, psicossocial e político. O poder político abrange todos os órgãos e funções de direção da Sociedade Política. É esse poder, por exemplo, que estabelece para o Estado o monopólio da coerção. O poder econômico é a manifestação do Poder do Estado através de fatos e fatores predominantemente econômicos. Abrange, por exemplo, o controle da inflação e das taxas de desemprego. A dimensão psicossocial envolve os fatos e fenômenos psicológicos e sociais. Segundo o Manual:

Assim, a Expressão Psicossocial trata do universo de fenômenos que a interessam sob
perspectivas que demandam interpretação filosófica e acurado estudo de dados
empíricos e científicos que são, predominantemente, objeto das ciências de
comportamento (...). Com o instrumental desse modo elaborado, a Expressão
Psicossocial busca a finalidade pragmática de obter aplicações fecundas, que
correspondem às expectativas com que é preparada e aplicada na realidade em que lhe
cabe atuar e influir. ${ }^{89}$

Dentro do campo psicossocial, por exemplo, está a influência ideológica que se exerceria pelo grau em que a população e as instituições sociais

\footnotetext{
${ }^{88}$ ESCOLA SUPERIOR DE GUERRA. Op. cit., p. 67.

${ }^{89}$ Ibid. p. 166
} 
participam do sistema de idéias e das ações características de uma ideologia ${ }^{90}$. A influência soviética dentro do País seria uma forma de influência ideológica, e poderia ser medida, segundo os militares, em 1964 com João Goulart na presidência, com um alto grau de participação não apenas da população, mas do próprio governo.

O poder militar consiste em manifestações de poder que tenham efeitos predominantemente militares, e possui suas raízes no uso da força. A Doutrina Militar seria, por exemplo, expressão do poder militar. Segundo o Manual:

A Doutrina Militar, contida numa Doutrina de Guerra e ambas atendendo aos conceitos
de uma Doutrina de Segurança Nacional, visa ao estabelecimento das bases para
organização, preparo e emprego das Forças Armadas. (...) A Doutrina Militar deve
atender aos acordos e alianças internacionais para que fique em consonância com o
atual espírito de segurança coletiva, tão momentoso quanto admissível. ${ }^{91}$ (grifos nosso)

Dessa forma, podemos entender que Doutrina de Segurança Nacional também corresponde a uma Doutrina Militar, e está, portanto, associada a um projeto militar que envolve organização, preparo e emprego das Forças Armadas.

A Segurança Nacional tem por finalidade a conquista ou manutenção dos Objetivos Nacionais, de modo a possibilitar a todos o Bem Comum. Transcrevemos abaixo o conceito oficial de Segurança Nacional da Escola:

É o grau de garantia que, através de ações políticas, econômicas, psicossociais e militares, o Estado proporciona, em determinada época, à Nação que jurisdiciona para a conquista ou manutenção dos objetivos nacionais, a despeito dos antagonismos ou pressões existentes ou potenciais. (grifo nosso) ${ }^{92}$

Se os antagonismos são de origem externa, situados no âmbito das relações internacionais, o problema é da Segurança Externa. Se, não importando a origem esses antagonismos, são manifestados ou produzem efeitos no âmbito interno do país, o problema será de Segurança Interna. Essas duas ramificações são compreendidas dentro do conceito de Segurança Nacional, que poderá dar maior ênfase aos problemas externos ou internos dependendo do país e da época. No caso do Brasil, a ênfase foi dada aos problemas internos.

\footnotetext{
${ }^{90}$ Ibid. p. 186

${ }^{91}$ Ibid. p. 197

${ }^{92}$ Ibid. p, 234
} 
Os objetivos nacionais, segundo o General Juarez Távora, em conferência durante o ano 1959, podem ser assim definidos:

Objetivos nacionais são realidades ou aspirações, relacionadas com a integração física, política, econômica ou social de uma nação, e que, consubstanciados no espírito da elite, se transmitem à sensibilidade do povo-massa como hábitos ou necessidades unânimes ou generalizadas da coletividade nacional.

A Lei de Segurança Nacional 6.620/1978 exemplifica alguns Objetivos Nacionais, tais como a Soberania Nacional, a Integridade Territorial, o Regime Representativo e Democrático, a Paz Social, a Prosperidade Nacional e a Harmonia Internacional.

A Segurança Nacional é proporcionada pelo Estado. Ele seria o maior responsável por proporcionar essa garantia. A sua finalidade é a conquista ou manutenção dos objetivos nacionais. Dessa forma, a Segurança Nacional possui um caráter de continuidade, já que mesmo depois de alcançados os objetivos nacionais, eles devem ser mantidos por meio da Segurança Nacional.

As ações de que trata o conceito oficial de Segurança Nacional abrangem qualquer atitude adotada pelo Estado, desde que em prol da segurança. Por isso, durante a ditadura militar, como veremos no capítulo seguinte, diversas ações, por mais arbitrárias que fossem, eram consideradas "legítimas" por terem como justificativa a segurança nacional. Na Carta de 1967, por exemplo, a pena de morte era prevista no art. $150 \S 11$, aplicando-se aos casos de guerra externa psicológica adversa, ou revolucionária ou subversiva. Por mais absurda que seja a pena de morte, dentro do contexto da segurança nacional, ela deve parecer necessária e justificável, dado os “antagonismos e pressões” existentes.

Por antagonismo e pressão, podemos entender qualquer mobilização ou movimento contrário ao regime. Relacionado com o contexto internacional, o antagonismo estaria vinculado com a possibilidade de, por intermédio da URSS, realizar-se no Brasil uma revolução comunista. Na prática, é evidente que os antagonismos não estavam ligados apenas aos comunistas vinculados ao projeto revolucionário. Muitas vezes, bastava discordar do regime vigente.

\footnotetext{
${ }^{93}$ Conferência do General Juarez Távora em 1959. Apud: ARRUDA, Antonio de. A Escola Superior de Guerra - História de sua Doutrina, p. 75.
} 
Os objetivos nacionais são os interesses que o regime buscava alcançar em nome da Nação. Eles são a finalidade máxima da Segurança Nacional. Podemos entender, então, que as políticas adotadas pelo regime foram pensadas por uma elite, tal como descreve o Manual, em nome da Nação, já que os brasileiros supostamente não estariam preparados para participarem das decisões políticas, motivo pelo qual alguém deveria decidir por eles, escolhendo o que é melhor para o País. Como exemplo, podemos citar todas as repressões que ocorreram, durante a ditadura militar, contra passeatas ou greves, já que o objetivo nacional da paz social não permitia qualquer mobilização por “deturpar a ordem pública”.

Não se pode, contudo, entender Segurança Nacional sem compreender que ela faz parte de um todo, no qual a noção de Desenvolvimento está incluída. Juntos formam a Doutrina de Segurança Nacional e Desenvolvimento. Segundo o Manual $^{94}$, o entendimento de Segurança Nacional pressupõe um processo de desenvolvimento contínuo do cidadão em busca da sua realização. Por outro lado, para que o desenvolvimento possa ser efetivo é necessário que haja segurança. Um sem outro não são possíveis, e guardam entre si relações de interdependência. Transcrevemos, abaixo, a explicação da ESG para justificar a interdependência entre segurança e desenvolvimento:

Seria lógico, por exemplo, imaginar-se o governo preocupado em melhorar o padrão de
vida dos seus cidadãos, que é baixo por definição num país subdesenvolvido, sem estar
preocupado, por igual, que ideologias insidiosas se apossam da mente desses mesmos
cidadãos? De outro lado, seria razoável admitir-se que um Estado possa estar
interessado em assegurar meios materiais às Forças Armadas, para o atendimento de
suas missões constitucionais, sem preocupar-se com a criação de um Parque Industrial
Nacional, capaz de produzir tais meios? ${ }^{95}$ (grifo nosso) Interessante notar que a Segurança não seria responsabilidade exclusiva do Poder Militar, mas exigiria ações de todas as expressões do Poder Nacional, além da participação de todos os cidadãos ${ }^{96}$. Isto indica não apenas que o Estado está a serviço da Nação, mas também que cada indivíduo junto com a sociedade é responsável por esse tipo de segurança. Segundo o General Eisenhower: “a Segurança Nacional é um estado de prontidão organizada e compreende todo o

\footnotetext{
${ }^{94}$ ESCOLA SUPERIOR DE GUERRA. Op. cit. p. 238-239

${ }^{95}$ Ibid. p, 238.

${ }^{96}$ Ibid. p, 239.
} 
povo, todos os empreendimentos e todo o governo.” ${ }^{97}$ A participação do cidadão na realização da Segurança Nacional é justificada, principalmente, quando o perigo, o inimigo encontra-se dentro do território nacional, ou seja, quando o problema é interno.

Essa concepção na qual o cidadão é responsável pela segurança nacional, especialmente, pela segurança interna, aparece em diversos textos legislativos da ditadura militar, tal como na Carta de 1967 e nas Leis de Segurança Nacional de 1967 e 1969, como explicaremos no capítulo seguinte. Mas, cabe ressaltar, desde já, que responsabilizar o cidadão pela segurança, supostamente justificaria punilo rigidamente, caso discordasse do regime vigente.

A chamada Estratégia de Ação Indireta seria a forma utilizada pela URSS para exportar a Revolução ${ }^{98}$. Essa estratégia compreende, principalmente, o insuflamento das pressões internas que gerariam a luta armada ideológica. Dessa forma, as contradições internas seriam exploradas visando soluções radicais, debilitando a segurança das comunidades de um país. Essa estratégia indireta serviria de justificativa, pelos militares, para combater qualquer mobilização social no País. Mesmo no final da década de 1970, quando os estudantes voltaram a fazer manifestações contra a ditadura, os militares insistiram que havia influência soviética por trás desses movimentos estudantis.

O conceito oficial de Segurança Interna, segundo o Manual da ESG, é a seguinte: "Segurança Interna, integrada na Segurança Nacional, diz respeito aos antagonismos ou pressões, de qualquer origem, forma ou natureza, que se manifestem ou produzam efeitos no âmbito interno do país." 99 Já a Defesa Interna possui a seguinte definição:

Conjunto de medidas levadas a efeito, para superar os antagonismos e pressões que se manifestem ou produzam efeitos no âmbito interno, atuando sobre seus agentes e seus efeitos, de forma a evitar, impedir ou eliminar o processo subversivo. Tais medidas, embora implicando a aplicação de todas as expressões do Poder Nacional, são particularmente da competência das expressões política e militar. (grifo nosso) ${ }^{100}$

\footnotetext{
${ }^{97}$ ARRUDA, Antonio de. Op. cit., p. 3.

${ }^{98}$ ESCOLA SUPERIOR DE GUERRA. Op. cit., p. 243.

${ }^{99}$ Ibid. p, 246

${ }^{100}$ Ibid. p, 246
} 
O processo subversivo seria sempre praticado por uma minoria com o objetivo de conturbar a ordem pública. Para isso, os agentes praticariam atos de terrorismo, assaltos, seqüestros e ações que visem perturbar a vida nacional, conduzindo à eclosão da luta interna. Essas minorias subversivas seriam "tenazmente atenuantes, fanáticas e intelectualizadas." 101

Para combater esse processo subversivo, responsabilidade do Estado, ele precisa criar um eficiente aparelho repressivo que possa garantir as instituições e manter o primado da lei e da ordem. Por isso, o Manual, como transcrevemos acima, ao explicar Defesa Interna, fala do conjunto de medidas para superar os antagonismos e pressões. Esse conjunto de medidas refere-se ao aparelho repressivo que foi criado durante a ditadura, e que justificou a atuação dos militares em todas as instâncias da repressão: informação, investigação, julgamento e punição. Dentre essas medidas, podemos destacar a criação do Serviço Nacional de Informações, o SNI, e a criação do Destacamento de Operações de Informações - Centro de Operações de Defesa Interna, o DOICODI.

A Segurança Nacional se apóia também nos novos conceitos de guerra que emergiram com a Guerra Fria. A Guerra total, Guerra limitada, Guerra declarada, Guerra não declarada (inclui a guerra revolucionária e insurrecional) e Guerra psicológica são os pontos que entendemos merecer destaque pela relação mais próxima que guardam com o conceito brasileiro de Segurança Nacional. Não estamos afirmando que todas essas concepções de guerra são necessariamente novas, mas certamente, nesse período, foram enfatizadas e mereceram grande atenção, não apenas no cenário da ESG, mas no cenário internacional também.

Nos primeiros anos de funcionamento da ESG foram enfatizados mais os assuntos militares em geral, assim como os problemas da Guerra, especificamente. A Guerra total foi, primeiramente, a maior preocupação e, em 1951, mereceu uma série de cinco conferências. Outra série de cinco conferências sobre a Guerra total foi feita também em 1954. Segundo um estudioso da ESG:

${ }^{101}$ Ibid. p, 247 
(...) a guerra fria e a guerra revolucionária puseram em destaque outros aspectos insidiosos da guerra contemporânea. Essas novas modalidades de conflito procuram o controle progressivo da Nação, pela destruição sistemática dos seus valores, das suas Instituições, do seu moral. A agressão já não vem apenas de fora, para qual basta a defesa, entregue às Forças Armadas. Agora, a população é atacada como um todo, e, para resguardá-la, é necessário algo mais abrangente. Surgiu daí um conceito novo, o de Segurança Nacional, mais amplo que o conceito de defesa. E a missão primordial conferida à ESG foi a de estudar a Segurança, dentro dessa nova concepção. ${ }^{102}$

A guerra total relaciona-se com a estratégia militar da Guerra Fria, em que o confronto não mais é limitado a uma área específica ou a setores específicos de uma população. O confronto é total e absoluto, abrangendo todas as ações que podem ser usadas para a hegemonia de uma nação sobre outra. Na ESG, a guerra total foi conceituada da seguinte forma:

Guerra Total é o conflito armado que interessa a todos os elementos da nação, num esforço conjunto que afeta todas as atividades públicas e privadas, tendo em vista a aplicação total do Poder Nacional, para a manutenção ou consecução dos Objetivos Nacionais. ${ }^{103}$

A guerra limitada pode ser compreendida dentro do quadro da guerra convencional ou nuclear, caracterizando-se pela limitação de objetivos políticos ou militares, do espaço geográfico e dos efeitos que se pretende obter. O Manual da ESG ${ }^{104}$ cita dois tipos de manobra possíveis para esse tipo de guerra: a manobra interior e a manobra exterior. A manobra interior desenvolve-se num espaço geográfico específico, onde a forma militar é aplicada dentro de objetivos bem definidos. A manobra exterior é caracterizada por ações diplomáticas e psicológicas, buscando resultados específicos para a guerra em questão.

A guerra declarada é a guerra clássica ${ }^{105}$. É sempre externa e entre Estados, reconhecida por organismos internacionais e utiliza a plena capacidade das forças militares. Dentro da guerra declarada são inseridas as guerras convencionais e nucleares. A guerra não declarada ou não clássica abrange a guerra revolucionária e insurrecional.

\footnotetext{
${ }^{102}$ ARRUDA, Antonio de. Op. cit., p. XXIV.

${ }^{103}$ Conferência da ESG de 1960. Apud: ARRUDA, Antonio de. Escola Superior de Guerra - História de sua Doutrina, p. 247.

${ }^{104}$ ESCOLA SUPERIOR DE GUERRA. Op. cit., p. 288.

${ }^{105}$ Ibid. p, 288-289.
} 
A guerra revolucionária desenvolve-se no campo da agressão indireta, podendo incluir o conflito armado no interior de um país. Relaciona-se diretamente com o comunismo, sendo um suposto instrumento de expansão soviética. Segundo o Manual da ESG:

\begin{abstract}
A guerra revolucionária comunista tem como característica principal o envolvimento da população do país-alvo numa ação lenta, progressiva e pertinaz, visando a conquista das mentes e abrangendo desde a exploração dos descontentamentos existentes, com o acirramento de ânimos contra as autoridades constituídas, até a organização de zonas dominadas, com o recurso à guerrilha, ao terrorismo e outras táticas irregulares, onde o próprio nacional do respectivo país-alvo é utilizado como combatente. É de concepção marxista-leninista. ${ }^{106}$
\end{abstract}

Os estudos da guerra revolucionária foram iniciados, em 1959, com uma conferência do então Coronel Augusto Fragoso ${ }^{107}$. Ele observou que esta modalidade de guerra é uma forma de subversão interna, é uma modalidade da guerra fria, mas não é a guerra fria, é uma guerra ideológica, mas não é a guerra ideológica. Maria Helena Moreira Alves ${ }^{108}$ atenta para o fato de que na guerra revolucionária, a guerra ideológica substituiu a guerra convencional entre Estados, dentro de um espaço geográfico definido.

A expressão, segundo o General Aurélio de Lyra Tavares ${ }^{109}$, foi usada, primeiramente, por Marx, depois por Lênin e, posteriormente, por Mao Tse Tung. Elio Gaspari ${ }^{110}$ corrige e explica que a expressão foi usada pela primeira vez por Mao Zedong em 1929, tendo como preocupação central o apoio do povo para se realizar.

O conceito de guerra revolucionária influenciou o pensamento francês e americano, justificando os eventos que aconteceram em Cuba, no Vietnã e na Argélia. Transcrevemos o conceito oficial de guerra revolucionária, segundo o Manual da ESG:

\footnotetext{
${ }^{106}$ Ibid. p, 291.

107 ARRUDA, Antonio de. Op. cit., p. 250-252.

108 ALVES, Maria Helena Moreira. Op. cit., p. 37.

109 Conferência do General Aurélio de Lyra Tavares em 1961. Apud: ARRUDA, Antonio de. Escola Superior de Guerra - História de sua Doutrina, p. 252-253.

110 GASPARI, Elio. Op. cit., p. 145.
} 
Conflito, normalmente interno, de concepção marxista-leninista, inspirado nesta ideologia, estimulado e, até mesmo, auxiliado do exterior, que, utilizando intensivamente a ação psicológica e todas as formas de subversão e violência, visa à conquista do poder pelo controle progressivo da Nação. ${ }^{111}$

No Brasil, a guerra revolucionária permeou toda a ditadura militar, de modo que os militares sentiam-se responsáveis por evitar que essa modalidade de guerra fosse instaurada no País. Para os oficiais, o Brasil seria um alvo estratégico importante da URSS, pelo seu tamanho continental e pela facilidade com que os seus cidadãos, sem o "conhecimento adequado", poderiam aderir à ideologia comunista.

Para os militares brasileiros, o uso da expressão guerra revolucionária significaria a apropriação da linguagem do adversário. Por isso, muitas vezes, os teóricos da ESG preferiram usar as expressões guerra subversiva ou mesmo insurrecional, embora o Manual diferencie esta da guerra revolucionária.

A guerra insurrecional está inserida dentro dos mesmos moldes da guerra revolucionária com a única diferença de não ter por motivação a ideologia comunista $^{112}$. É a guerra em que parte da população auxiliada ou reforçada por influências advindas do exterior, se contrapõe ao governo que detém o poder, visando a sua deposição ou subjugação. Ambas as guerras estão estritamente vinculadas à idéia de guerra limitada. A possibilidade remota do confronto entre os EUA e a URSS, caracterizado pelos teóricos da ESG como suicídio coletivo da humanidade, levaria a intensificação das agressões indiretas por parte da URSS.

A guerra psicológica compreende o uso intenso de propaganda e outras ações capazes de influenciar opiniões, comportamentos e emoções de grupos adversos ou neutros, visando apoio para a concretização dos Objetivos Nacionais ${ }^{113}$. Ela foi estudada na ESG pela primeira vez, em 1950, durante uma conferência do Brigadeiro Armando Ararigboia.

\footnotetext{
${ }^{111}$ ESCOLA SUPERIOR DE GUERRA. Op. cit. p. 304.

${ }^{112}$ Ibid. p. 291

${ }^{113}$ Ibid. p. 320-323
} 
A guerra psicológica tem por objetivo desmoralizar o inimigo, isolando-o do resto da população, obtendo dessa forma vantagens militares, mas sem o emprego da força armada, incentivando, inclusive, a delação. Essa modalidade de guerra atua, então, na própria população do País, para que os cidadãos junto com o Estado combatam o "inimigo interno". O Conselho de Segurança Nacional, o Estado-Maior das Forças Armadas, o Ministério das Relações Exteriores e o Serviço Nacional de Informações são os responsáveis pela execução da guerra psicológica. Para a ESG:

O aspecto psicológico da guerra avulta sobremaneira em nossa época, como conseqüência natural da sofisticação dos meios de comunicação, dando motivo ao nascimento do que se pode chamar guerra psicológica, tão temível e poderosa que pode destruir o inimigo pelo fabuloso poder de penetrar-lhe o espírito e miná-lo a ponto de anular qualquer esforço de defesa, sem que seja necessário, por vezes, o disparo de um único tiro. ${ }^{114}$

Para a efetivação da guerra psicológica, as informações seriam de extrema relevância, pois poderiam sugerir alvos, áreas de emprego, temas e os meios a serem utilizados. A guerra psicológica possui como finalidades: diminuir a capacidade combativa do inimigo, impedir ou desencorajar ações contrárias ao interesses nacionais, através de propaganda, ou de demonstrações ostensivas de força e produzir efeitos depressivos na moral do adversário.

Segundo o Manual da ESG, a grande preocupação do Brasil, assim como da América Latina, era a guerra revolucionária, representada pelo inimigo interno. A teoria do inimigo interno conduz o governo ao desenvolvimento de dois tipos de estrutura defensiva ${ }^{115}$. Primeiro, deve ser criado um aparato repressivo e de controle armado que imponha sua vontade e intimide a população. Depois, o Estado montará uma complexa rede de informações que torne possível detectar o inimigo, pois se ele é interno, pode estar em qualquer lugar, atuando através da ação comunista indireta. As ações praticadas visando

\footnotetext{
${ }^{114}$ Ibid. p. 316

${ }^{115}$ ALVES, Maria Helena Moreira. Op. cit., p. 37.
} 
coagir supostas infiltrações comunistas dotaram os militares de poderes quase ilimitados, como verificaremos a seguir.

$\mathrm{O}$ perigo era de fato o comunismo, e a bandeira brasileira associada à americana, evidente, defendia a democracia e a ordem vigente, embora os EUA tenham ajudado a cúpula militar a romper com essa mesma democracia e a quebrar essa mesma ordem. As contradições são evidentes, não existindo conceito capaz de escondê-las para desfigurar a realidade em que o País viveu por mais de vinte anos. As palavras ordem e democracia aparecem muitas vezes no Manual da ESG, inúmeras vezes, mas pouquíssimas vezes aparecem as palavras liberdade, liberdade de expressão, liberdade política, liberdade de associação.

A adoção do princípio de defesa coletiva, na década de 1950, que resultou em inúmeros acordos militares na América Latina, reuniu todo o continente contra o comunismo. De alguma forma, a estratégia supunha que as forças militares brasileiras estariam a serviço dos interesses norte-americanos. Muitos oficiais latino-americanos seriam treinados em unidades militares nos EUA e na Escola das Américas, na Zona do Canal do Panamán ${ }^{116}$. A partir de 1960, e possivelmente até 1968, toda a turma de estagiários, que concluísse o curso anual da ESG, fazia uma viagem aos EUA, visitando, inclusive, o National War College. $^{117}$

Nos ensinamentos americanos, que ocorriam durante esses cursos de intercâmbio, estava embutida a prática de tortura. Da lista dos estagiários, entre 1965 e 1970, um em cada dez oficiais enviados ao Panamá, pela ditadura, fora ou viria a ser nominalmente acusado de tortura ou morte de presos. ${ }^{118}$ Só para citar alguns, o oficial da mais alta patente na turma de 1965, o Comandante Clemente José Monteiro Filho, fundaria a central de torturas da ilha das Flores. O Coronel

\footnotetext{
${ }^{116}$ A lista dos estagiários da Escola das Américas está no site do School of Americas Watch: http://www. soaw.org

${ }^{117}$ DREIFUSS, Réne Armand. Op. cit., p. 79

${ }^{118}$ GASPARI, Elio. A Ditadura Escancarada, p. 305. $5^{\text {a }}$ reimpressão. São Paulo: Companhia das Letras, 2009. $507 \mathrm{p}$.
} 
Hélio Ibiapina foi o responsável pela violência do Recife nos primeiros meses da ditadura. ${ }^{119}$

A ESG sempre manteve introjetada, nos seus ensinamentos, as concepções da Guerra Fria. Alinhou-se, evidentemente, ao lado do bloco ocidental. Os EUA, principalmente após a Revolução Cubana de 1959, mantiveram uma postura vigilante na América Latina, baseada no fortalecimento dos militares na região, vistos como os responsáveis para combater qualquer possível sonho revolucionário. ${ }^{120}$

A forma, contudo, como a segurança nacional foi expressa nos EUA e no Brasil difere substancialmente. Certamente, em ambos os países o anticomunismo estava presente de forma intensa, mas no Brasil as Forças Armadas foram acionadas para combater o "inimigo interno", instaurando a ditadura no País. Aqui a segurança nacional era uma questão de prisões, arbitrariedades, torturas.

O conceito de segurança nacional norte-americano da Guerra Fria envolvia a necessidade do desenvolvimento tecnológico de mais alto nível, de uma moderna indústria bélica e da afirmação do País como potência mundial superior à URSS.

Nos EUA, ao contrário do Brasil, como veremos mais especificamente, não foi tirado dos cidadãos o direito ao voto, nem foi criado um rígido aparelho repressivo responsável pelas violências mais aberrantes, sem qualquer respeito às liberdades individuais e coletivas. Suas instituições tampouco foram desmobilizadas em vida. Segundo Maria Celina D’Araujo:

Segurança nacional, como projeto nas democracias do Norte, é muito diferente do que se passou no Brasil onde os militares são alocados para combater inimigos internos. Aqui a segurança nacional era uma questão de cadeias e prisões e não de tecnologia em escala. ${ }^{121}$

\footnotetext{
${ }^{119}$ Ibid. p, 305.

${ }^{120}$ FICO, Carlos. O grande irmão - Da operação Brother Sam aos anos de chumbo, p. 25.

${ }^{121}$ D'ARAUJO, Maria Celina. Op. cit.
} 


\section{O objetivo e o propósito: a ditadura militar e a segurança nacional}

"É a ordem que não pode viver sem a desfiguração dos homens." (Adorno e Horkheimer - Dialética do Esclarecimento)

\subsection{4-1967: a segurança nacional antes dos anos de chumbo}

A intervenção militar de 1964 certamente difere das outras perpetradas pelos militares. O caráter intervencionista, que há muito envolvia a instituição, chegou ao ápice durante a ditadura militar. A segurança nacional, naquele momento, serviu como um grande propósito que merecia, portanto, a proteção militar contra diversos movimentos supostamente "subversivos" que assombravam o País. Não era difícil usá-la como justificativa, já que conseguia envolver muitas idéias em um só conceito: segurança, moralidade, desenvolvimento, estabilidade, anticomunismo, para citar apenas alguns. Sua interpretação parecia quase inesgotável.

Não trataremos, nesse trabalho, das complexidades que envolveram a articulação do golpe de 1964, nem de todos os eventos militares posteriores, mas de como a segurança nacional foi utilizada para a manutenção da ditadura, justificando repressões e perseguições políticas, principalmente, através de rigorosas medidas legislativas.

Com a renúncia de Jânio Quadros à Presidência da República, em 1961, João Goulart, Vice-Presidente, assumiu o cargo, em meio a muitas contrariedades da cúpula militar e da elite civil. As conspirações para depô-lo começaram logo após a sua posse. Ao todo, o General Golbery do Couto e Silva, que em 1952 foi designado como adjunto do Departamento de Estudos da ESG, passou dez anos escrevendo manifestos contra Jango, e não estava sozinho ${ }^{122}$. Junto com ele foram se aglutinando mais e mais conspiradores, na medida em que Jango lutava

\footnotetext{
${ }^{122}$ GASPARI, Elio. A ditadura derrotada, p. 165.
} 
pelas chamadas reformas de base, reformas estas que a estrutura brasileira tanto precisava.

O desejo da cúpula militar de depor o Presidente não surgiu, unicamente, dos eventos de março de 1964: o comício do dia 13, o episódio dos marinheiros, a solenidade do Automóvel Clube. Esse desejo era mais antigo e foi afirmado quando Jango, por plebiscito, retomou os poderes políticos que lhe foram tirados em setembro de 1961 com a instituição do parlamentarismo. O alto comando militar não podia suportar. Não podia suportar também as reformas em curso e o avanço da mobilização política com intensa participação popular. Aos militares uniram-se forças conservadoras civis. No dia $1^{\circ}$ de abril de 1964, circulava nos quartéis um manifesto assinado pelos generais Castello Branco, Costa e Silva e Decio Escobar. Foi o último manifesto escrito por Golbery contra Jango. ${ }^{123}$ No dia 2 de abril estava aberta vaga à Presidência.

Até que um novo Presidente fosse eleito, o presidente da Câmara dos Deputados, Ranieri Mazzilli, assumiria o cargo. O poder, no entanto, estava nas mãos do Alto Comando da Revolução composto pelo General Arthur da Costa e Silva, Almirante Augusto Rademaker e pelo Brigadeiro Correia de Melo. Foi sob o comando deles que o primeiro Ato Institucional (AI) foi editado. Era de fato um instrumento inédito em nossa história. Foi redigido pelo jurista Francisco Campos, autor da Carta de 1937.

O AI previa a manutenção da Constituição de 1946 e das Constituições estaduais $\left(\operatorname{art.} 1^{\circ}\right)$. Tratava da sucessão presidencial, que seria realizada pela maioria absoluta do Congresso Nacional (art. $2^{\circ}$ ). Os mandatos do Presidente e do Vice-Presidente chegariam ao fim no dia 31 de janeiro de 1966, mas foram prorrogados por um ano pelo Congresso, em julho de 1964. O AI prevê o funcionamento do Congresso, ao mesmo tempo em que possibilita a cassação de mandatos federais, estaduais e municipais sem qualquer apreciação judicial (art. 10). Os direitos políticos podiam ser suspensos por dez anos, também sem apreciação judicial (art. 10). Havia muita rigidez em relação aos funcionários

\footnotetext{
${ }^{123}$ Ibid. p. 165.
} 
públicos. As garantias de vitaliciedade e estabilidade estavam suspensas por seis meses (art. $\left.7^{\circ}\right)$.

$\mathrm{O}$ art. $8^{\circ}$ prevê que "os inquéritos e processos visando à apuração da responsabilidade pela prática de crime contra o Estado ou seu patrimônio e a ordem política e social ou de Atos de guerra revolucionária poderão ser instalados individual ou coletivamente.” Esse artigo lançou as bases dos Inquéritos Policiais Militares (IPMs), que viriam a atingir milhares de pessoas em todo o País. No dia 27 de abril de 1964, o governo Castello Branco baixou o dec. 53.897, instituindo os IPMs. Nessa época, as decisões dos IPMs ainda podiam ser revistas pelo Poder Judiciário que, geralmente, revogavam as suas decisões.

A possibilidade de cassar mandatos eleitorais e suspender direitos políticos só poderia ser aplicada até sessenta dias após a posse do Presidente Castello Branco, ou seja, 15 de junho de 1964. Essa limitação temporal do AI levou ao descontentamento muitos oficiais superiores, que acreditavam na necessidade de expurgar aqueles que eles designavam, arbitrariamente, como comunistas, "subversivos", corruptos. Dessa insatisfação, novas demandas surgiriam e culminariam no AI-2.

No AI, a expressão segurança nacional aparece apenas quando o Conselho de Segurança Nacional é citado. Fala-se em segurança, paz, "honra nacional”. O General Augusto Fragoso ao tratar, numa conferência da ESG, sobre a Legislação de Segurança Nacional, analisa:

Os Atos Institucionais, emanados do chamado 'Poder Constituinte Originário' da Revolução, representam 'a suprema expressão de sua força normativa'. Ensina Frederico Marques que 'é de tal preeminência a posição hierárquica do Ato Institucional, entre as normas do Direito escrito, que a própria Constituição se coloca, perante ele, em posição subalterna'. ${ }^{124}$

Fazia parte da estratégia política elaborada na ESG a vigilância e o controle dos partidos políticos, do Legislativo, do Judiciário e do Executivo. O Congresso podia continuar funcionando, mas desde que nele não estivesse mais

\footnotetext{
${ }^{124}$ FRAGOSO, Augusto. Legislação de Segurança Nacional, p. 4. Conferência na Escola Superior de Guerra, 13 de agosto de 1975. Separata da Revista do Superior Tribunal Militar nº 1, 1975. 93 p.
} 
qualquer parlamentar vinculado ao governo anterior ou passível de desafiar o novo governo vigente. Na burocracia civil, assim como dentro da própria instituição militar, a "limpeza” de indivíduos indesejados também ocorreu.

Era necessário que a ESG e a extrema direita predominassem nas Forças Armadas, eliminando legalistas e nacionalistas. Durante os primeiros meses do regime militar, estima-se que 50.000 pessoas foram presas. Entre 1964 e 1966, cerca de dois mil funcionários públicos foram demitidos, e 386 pessoas tiveram seus mandatos cassados e/ou perderam seus direitos políticos por dez anos. Dentro da organização militar, 421 oficiais passaram para a reserva, como punição, e 24 dos 91 generais foram expurgados. Nos primeiros nove meses de regime, nove pessoas, dentre os mais de treze mortos, foram dadas como suicidas. Algumas pessoas teriam "se suicidado" da mesma forma que Victor Allen Barron, comunista, em 1936, se atirando no pátio interno do prédio da Polícia Central do Rio de Janeiro. ${ }^{125}$

O Almirante Cândido Aragão, comandante dos fuzileiros navais de João Goulart, foi brutalmente torturado nos dois meses em que ficou preso na fortaleza do Lage. ${ }^{126}$ A atitude tomada pela Marinha em relação ao Almirante acabava com a idéia de respeito e hierarquia que havia, ao menos, entre os militares, a despeito de suas posições políticas. Nem Luís Carlos Prestes, militar e comunista, foi fisicamente torturado durante o Estado Novo ${ }^{127}$. Esse era apenas o início de um processo de anarquização e desordem militar que marcaria o período da ditadura.

As Forças Armadas brasileiras estavam muito divididas em relação às questões políticas, embora tenham sido capazes de se mostrar como um bloco.

\footnotetext{
${ }^{125}$ GASPARI, Elio. A ditadura envergonhada, p. 130-132. 6a reimpressão. São Paulo: Companhia das Letras, 2009. $417 \mathrm{p}$.

${ }^{126}$ Ibid. p, 133.

${ }^{127}$ Nas palavras de Prestes: "Pessoalmente, não fui torturado: a minha tortura foi toda psicológica. Mas sofri maus-tratos como dezenas de outros companheiros. Houve muito assassinato, muito espancamento. O ano de 1936 foi de repressão violenta (...).” "Era uma coisa medieval. Fui colocado lá junto com o Berger, que estava enlouquecido e gritava à noite. Eu gritava algumas palavras em alemão ou inglês, ele ouvia do outro lado do cubículo e se acalmava alguns minutos. Era um inferno. Queriam me enlouquecer.” (CAMARGO, Aspásia. O golpe silencioso: as origens da república corporativa, p 244. Rio de Janeiro: Rio Fundo, 1989. 279 p.)
} 
Ainda havia militares que defendiam a permanência de Jango na Presidência. Eram chamados de legalistas. Havia também aqueles mais inclinados para a esquerda, muito mobilizados pelas discussões que envolviam a nacionalização do petróleo. Após o golpe, nasceu a expressão "linha dura” para designar os oficiais ultra-“revolucionários” e, geralmente, indisciplinados. Era recorrente que usassem os IPMs como forma de afirmação de poder. A ESG, dentro do panorama militar, soube se colocar muito bem. O primeiro Presidente, o General Castello Branco, era um esguiano. Colocou na chefia do Gabinete Militar da Presidência outro esguiano, o General Ernesto Geisel, que viria a ser Presidente em 1974. Durante o governo do General Castello Branco, foi criado o Serviço Nacional de Informações, o SNI, foram editados três Atos Institucionais, uma nova Constituição foi outorgada e um Decreto- lei (DL), definindo os crimes contra a segurança nacional, foi editado.

O SNI foi criado pelo Decreto- lei no 4341 de 13 de junho de 1964. Fazia parte de uma estratégia da ESG na qual a segurança interna dependeria de informação. Era preciso conhecer e combater o “inimigo interno”. O SNI foi criado “como órgão da Presidência da República (...) para os assuntos atinentes à Segurança Nacional, e operará também em proveito do Conselho de Segurança Nacional” (art. $1^{\circ}$ ). A sua finalidade era "superintender e coordenar, em todo o território nacional, as atividades de informação e contra informação, em particular as que interessem à Segurança Nacional” (art. $2^{\circ}$ ).

O General Golbery do Couto e Silva, esguiano, foi o criador e o primeiro diretor do SNI. Dirigiu-o até 1967. Como chefe do SNI tinha status de ministro do governo e integrava o gabinete. Em 1981, chamou o SNI, que ele mesmo criou, de "monstro", e saiu do governo afirmando: "Vocês pensam que vão controlar o país cometendo crimes e encobrindo seus autores, mas estão muito enganados. Vão ser postos daqui para fora com um pé na bunda.” 128

O SNI devia satisfações apenas ao Presidente da República, o que revela a imensa importância do órgão e da função que cumpria, ou seja, servir como rede

${ }^{128}$ GASPARI, Elio. A ditadura envergonhada, p. 36. 
de espionagem. Segundo Elio Gaspari, "o SNI nasceu fazendo em segredo tudo aquilo que a Presidência precisava que fosse bem-feito.” ${ }^{129}$ Foi a primeira lei da ditadura militar a falar em segurança nacional.

Em 1965, ocorreram eleições para Governadores de onze estados, mas o resultado não foi favorável ao regime. Da derrota eleitoral, a inquietação militar com o resultado. Das pressões destes eventos, foi editado o AI-2, de 27 de outubro de 1965, três semanas depois das eleições, e o primeiro a ser numerado. O AI-2 ficaria em vigor até a posse do Presidente Costa e Silva, em 15 de março de 1967. Foi o primeiro também a introduzir mudanças na Justiça Militar (art. $8^{\circ}$ ). Segundo esta legislação de caráter excepcional, os partidos políticos eram extintos (art.18), aumentava a capacidade de intervenção do governo federal nos estados (art. 17), reabria a temporada de cassações (art. 15), diluía o Supremo Tribunal Federal (art. $6^{\circ}$ ), que seria composto por dezesseis ministros, e acabava com a eleição direta para Presidente (art. $9^{\circ}$ ).

Na Justiça Militar, o número de ministros passaria de onze para quinze, e caberia a este tribunal o julgamento de todos os crimes contra a segurança nacional, cometidos por civis ou militares (art. $8^{\circ}$ ). Nesse momento, a Lei de Segurança Nacional em vigor era a Lei 1802/1953. Nela encontram-se todos os crimes contra a segurança nacional. Esse aumento da competência da Justiça Militar foi extremamente importante e se acentuou ao longo da ditadura com as constantes modificações das Leis de Segurança Nacional. Mostra como o aparelho repressivo militar passaria a envolver informação e julgamento. Todas as fases de combate ao comunismo necessariamente passariam pelos militares, de tal forma que não foi criado um tribunal de exceção para julgamento, como ocorreu nos anos 1930, optando-se por usar o próprio STM para cumprir esse papel. O General Golbery, justifica a mudança ocorrida na Justiça Militar:

\footnotetext{
A expressão "segurança externa" constante do texto atual (Constituição de 1946) é por demais restritiva, além de não corresponder ao conceito moderno e integrado de segurança nacional, de que as agressões de origem externa não mais deixaram de estimular, coordenadamente, ações subversivas no interior do território agredido (...) e, sobretudo, na fase atual da luta ideológica entre o Ocidente democrata e o Oriente
}

\footnotetext{
${ }^{129}$ Ibid. p, 168.
} 
comunista quando a forma normal de agressão é, sabidamente, a subversiva ou insurrecional, apoiada intelectual e quase sempre até materialmente, desde o exterior. $(\ldots)^{130}$

O preâmbulo do AI-2 não fala apenas naqueles que tentavam "bolchevizar o país”, mas naqueles que “desafiam e ameaçam a própria ordem revolucionária”. O raio de ação do inimigo interno aumentou, junto com o aumento de competência da Justiça Militar. O inimigo não era apenas os comunistas, mas qualquer opositor ao governo. Outra novidade no preâmbulo era a introdução da expressão desenvolvimento econômico como um dos objetivos do País. Juntamente com a segurança nacional, diversas vezes citada no texto, constituíam um binômio que a ESG aguardou muito para usar.

Foi após o AI-2 que as Auditorias Militares apareceram em cena. Elas se situavam nas Circunscrições Judiciárias Militares (CJM), e não faziam parte da Justiça Militar na qualidade de Poder Judiciário. Serviram como locais para interrogatório, prisão e tortura.

O AI-3, de 5 de fevereiro de 1966, tornava indireta as eleições para Governadores (art. $1^{\circ}$ ). Esta modificação, que permitia a nomeação dos Secretários de Segurança dos estados pelo governo federal, possibilitava a um comandante militar a direção das operações policiais destes estados. Os Governadores aceitavam essa interferência como parte do pacto político a que se haviam vinculado. Nas capitais, os prefeitos seriam nomeados pelos Governadores, mediante prévio assentimento da Assembléia Legislativa (art. $4^{\circ}$ ). Nos demais municípios, a eleição para prefeito seria direta. A partir deste Ato e do AI-2, os brasileiros passariam dezessete anos sem eleger Governadores e quase um quarto de século sem eleger o Presidente.

Com o golpe de 1964, a continuidade da Constituição de 1946 era promessa recorrente, mas, em dezembro de 1966, ela "não atendia mais as exigências nacionais” (preâmbulo da Carta de 1967). Se tudo corresse como prometido, o Brasil, em 1965, estaria escolhendo seu novo Presidente, mas Costa e Silva, sucessor de Castello Branco, foi escolhido por 295 pessoas no Congresso

\footnotetext{
${ }^{130}$ Ibid. p, 255.
} 
Nacional. O AI-4, de 7 de dezembro de 1966, prevê o procedimento da Constituinte. Em janeiro de 1967, foi outorgada uma nova Constituição.

Mário Pessoa $^{131}$, integrante do Corpo Permanente da ESG, no seu livro $O$ Direito da Segurança Nacional, explica que, a partir da Carta de 1967, a segurança nacional é usada com perfeita propriedade em relação ao que deseja exprimir, além de se diferenciar do modo como foi expressa nos textos anteriores, ao trazer a vantagem técnica da unificação terminológica. Os anos de estudo da ESG mostravam seus resultados.

No art. 89 da Carta de 1967, uma idéia muito cara aos defensores da segurança nacional é expressa. O artigo prevê que "toda pessoa natural ou jurídica é responsável pela segurança nacional, nos limites definidos em lei”, ou seja, a segurança nacional não é responsabilidade apenas do governo, mas também de todos os indivíduos pertencentes a um mesmo país, de modo que juntos combatam o inimigo que neste mesmo país reside. Antônio de Arruda explica:

Surgiu, pois, a noção de segurança, encarada como um estado de alerta, de prevenção, de consciência do perigo. E como este não ameaça o indivíduo, mas toda a Nação, força é que esta se ponha em guarda como um todo. Daí o preceito da nossa Constituição. ${ }^{132}$

O art. 89 é o primeiro artigo da seção dedicada à Segurança Nacional que trata, exclusivamente, do Conselho de Segurança Nacional (CSN). O CSN está presente em textos constitucionais desde 1934, mas desta vez contava com uma ajuda importantíssima: “a cooperação dos órgãos de Informação” (art. 91).

A Justiça Militar tem mais uma vez seu raio de ação ampliado, sendo competente para julgar além de militares e civis, os Governadores de Estado e seus Secretários em casos de crimes contra a segurança nacional ou contra as instituições militares. Nesse momento, ainda era possível recorrer ao Supremo Tribunal Federal que, geralmente, abrandava as penas. ${ }^{133}$

Art. 122. - A Justiça Militar compete processar e julgar, nos crimes militares definidos em lei, os militares e as pessoas que lhes são assemelhadas.

\footnotetext{
${ }^{131}$ PESSOA, Mário. Op. cit., p, 116.

${ }^{132}$ ARRUDA, Antonio de. Op. cit., p. 5.

${ }^{133}$ ALVES, Maria Helena Moreira. Op. cit. p. 57.
} 
$\S 1^{\circ}$ - Esse foro especial poderá estender-se aos civis, nos casos expressos em lei para repressão de crimes contra a segurança nacional ou as instituições militares, com recurso ordinário para o Supremo Tribunal Federal.

$\S 2^{\circ}$ - Compete originariamente ao Superior Tribunal Militar processar e julgar os Governadores de Estado e seus Secretários, nos crimes referidos no $\delta 1^{\circ}$. (grifo nosso)

O art. 150 da Carta de 1967, com a redação dada pelo AI-14 de 5 de setembro de 1969, reintroduziu no ordenamento jurídico a pena de morte, em caso de guerra externa psicológica adversa, ou revolucionária ou subversiva. Estão presentes, então, diversos novos conceitos de guerra que emergiram com a Guerra Fria, tal como expomos anteriormente. Abaixo, transcrevemos o respectivo artigo:

Art. 150 - A Constituição assegura aos brasileiros e aos estrangeiros residentes no Pais a inviolabilidade dos direitos concernentes à vida, à liberdade, à segurança e à propriedade, nos termos seguintes:

$\S 11$ - Não haverá pena de morte, de prisão perpétua, de banimento, ou confisco, salvo nos casos de guerra externa psicológica adversa, ou revolucionária ou subversiva nos termos que a lei determinar. Esta disporá também, sobre o perdimento de bens por danos causados ao Erário, ou no caso de enriquecimento ilícito no exercício de cargo, função ou emprego na Administração Pública, Direta ou Indireta. (grifo nosso)

Com tantas mudanças legislativas, entendeu-se necessário mudar também a Lei de Segurança Nacional, para atualizá-la aos novos ditames do regime militar. O Decreto- lei $n^{\circ} 314$ de 13 de março de 1967, foi editado menos de dois meses depois de outorgada a Constituição, tendo como base o AI-2. O art. $4^{\text {o }}$ prevê que "na aplicação deste decreto-lei o juiz, ou Tribunal, deverá inspirar-se nos conceitos básicos da segurança nacional definidos nos artigos anteriores.” Os conceitos básicos de que fala o DL 314 são segurança nacional, guerra psicológica e guerra revolucionária, e correspondem exatamente aos estipulados no Manual Básico da ESG. Transcrevemos, segundo o DL 314, estes conceitos 134 :

Art. $1^{\circ}$ Toda pessoa natural ou jurídica é responsável pela segurança nacional, nos limites definidos em lei.

\footnotetext{
${ }^{134}$ Para a comparação entre os conceitos definidos no DL 314 e os conceitos do Manual da ESG, ver o ANEXO I.
} 
Art. $2^{\circ}$ A segurança nacional é a garantia da consecução dos objetivos nacionais contra antagonismos, tanto internos como externos.

Art. $3^{\circ}$ A segurança nacional compreende, essencialmente, medidas destinadas à preservação da segurança externa e interna, inclusive a prevenção e repressão da guerra psicológica adversa e da guerra revolucionária ou subversiva.

$\S 1^{\circ}$ A segurança interna, integrada na segurança nacional, diz respeito às ameaças ou pressões antagônicas, de qualquer origem, forma ou natureza, que se manifestem ou produzam efeito no âmbito interno do país.

$\S 2^{\circ}$ A guerra psicológica adversa é o emprego da propaganda, da contrapropaganda e de ações nos campos político, econômico, psicossocial e militar, com a finalidade de influenciar ou provocar opiniões, emoções, atitudes e comportamentos de grupos estrangeiros, inimigos, neutros ou amigos, contra a consecução dos objetivos nacionais.

$\S 3^{\circ}$ A guerra revolucionária é o conflito interno, geralmente inspirado em uma ideologia ou auxiliado do exterior, que visa à conquista subversiva do poder pelo controle progressivo da Nação.

Art. $4^{\circ} \mathrm{Na}$ aplicação deste decreto-lei o juiz, ou Tribunal, deverá inspirar-se nos conceitos básicos da segurança nacional definidos nos artigos anteriores.

A novidade consistia nas inúmeras ramificações dos tipos penais. Com cerca de sessenta artigos, o DL 314 estipulava as diversas, quase inesgotáveis, formas de subversão com auxílio de potência estrangeira, demonstrando a preocupação do legislador de cobrir qualquer ação que pudesse atentar contra o regime vigente. No art. 46 há a possibilidade de instauração de processos individuais ou coletivos para qualquer dos delitos previstos. O DL 314 prevê também, no art. 47, que o recurso ordinário para o STF, nos casos de crime contra a segurança nacional, será interposto da decisão final do Superior Tribunal Militar.

Entre 1967, data da primeira Lei de Segurança Nacional da ditadura militar, e 1983, data da LSN em vigor no País, são sete os textos legais mais importantes que regulam o tema. Por mais que o legislador tentasse tipificar qualquer possibilidade de atentado ao regime vigente, as Leis de Segurança Nacional, principalmente, em momentos de autoritarismo sempre se mostraram suscetíveis a mudanças que apontam para questões do momento. Segundo Maria Celina D’Araujo: “são leis para tratar de conjunturas específicas e que tanto nos 
anos 1930 quanto nos anos 1960, tiveram nos militares os principais ideólogos e promotores da mudança.” 135

\subsection{Entre 1968 e 1974: a segurança nacional nos anos de chumbo}

No dia 15 de março de 1967, o General Castello Branco entregou a Presidência da República ao Marechal Arthur da Costa e Silva, contra a vontade de Golbery e Geisel. Enquanto o General Ernesto Geisel foi ocupar o cargo de ministro no STM, o General Golbery foi trabalhar no Tribunal de Contas. Juntos retornariam ao governo, em 1974, para desfazerem a ditadura que ajudaram a construir. Durante o governo de Costa e Silva, o mais severo e autoritário instrumento legislativo da ditadura militar entrou em vigor, o AI-5. Este Ato Institucional trazia uma marca profunda no seu texto, que o regime militar demoraria dez anos e dezoito dias para revogar: a extinção do habeas corpus.

O ano de 1968 foi um daqueles momentos da história em que o tempo parecia passar mais rapidamente que o comum. Diversos países viviam mobilizações, transformações, acontecimentos graves. A primavera de Praga, maio de 1968 em Paris. No Brasil, dois estudantes foram baleados (Edson Luís no dia 28 de março e José Carlos no dia 2 de outubro), dois militares estrangeiros foram assassinados (Edward Von Westernhagen no dia $1^{\circ}$ de julho e Charles Chandler no dia 12 de outubro), grandes manifestações sociais ocorreram entre março e outubro, diversos ataques a espetáculos, prisões de artistas e estudantes (Ibiúna no dia 12 de outubro) foram perpetrados, para citar apenas alguns fatos. Fernanda Montenegro, numa carta a Clarice Lispector publicada no Jornal do Brasil em 19 de outubro de 1968, relata:

Atualmente em São Paulo se representa de arma no bolso. Polícia nas portas dos teatros. Telefonemas ameaçam o terror para cada um de nós em nossas casas de gente de teatro. É o nosso mundo. E o nosso mundo, Clarice? Não este, pelas circunstâncias obrigatoriamente político, polêmico, contundente. Mas aquele mundo de que nos fala Tchecov: onde repousaremos, onde nos descontrairemos? Ai, Clarice, a nossa geração

\footnotetext{
${ }^{135}$ D’ARAUJO, Maria Celina. Op. cit.
} 
não a verá. Quando eu tinha quinze anos, pensava alucinadamente que a minha geração desfaria o nó. (...) A luta que fizermos não o faremos pra nós. ${ }^{136}$

No dia 12 de dezembro de 1968, os generais mais graduados do quartelgeneral do Rio procuraram o Ministro do Exército, o General Lyra Tavares. O oficialato dos principais centros de instrução do Exército, a Escola de Aperfeiçoamento de Oficiais e a Escola de Comando e Estado-Maior, estava insatisfeito. Eles queriam um golpe ${ }^{137}$. No dia 13 de dezembro, o Marechal Costa e Silva presidiu uma reunião do Conselho de Segurança Nacional. Em frente à mesa de cada ministro constava uma cópia do AI-5, escrito pelo Ministro da Justiça, Luís Antonio da Gama e Silva. Contra o Ato Institucional, nenhum ministro se manifestou de forma veemente, a seu favor, mesmo com ressalvas, todos. ${ }^{138} \mathrm{O}$ golpe estava dado.

Segundo o livro Brasil: nunca mais ${ }^{139}$, as Forças Armadas valeram-se de três pretextos para desencadear o AI-5: as denúncias de tortura sustentadas dentro do partido de oposição, o crescimento das manifestações de rua e o surgimento de grupos de oposição armada, que alegavam não ser mais possível combater a ditadura pela via institucional. Estas foram as justificativas usadas pelo regime, afirmadas pelo clima de medo e terror criado e explorado pelos militares da linha dura. Era preciso que o AI-5 parecesse necessário, quase inevitável para a sociedade brasileira.

O AI-5 teria como justificativa assegurar uma "autêntica ordem democrática, baseada na liberdade, no respeito à dignidade da pessoa humana, no combate à subversão e às ideologias contrárias às tradições de nosso povo, na luta contra a corrupção” (preâmbulo do AI-5). O Governo da República seria o responsável “pela ordem e segurança internas”, e não poderia “permitir que pessoas ou grupos anti-revolucionários contra ela trabalhem, tramem ou ajam,

\footnotetext{
${ }^{136}$ Carta publicada no Jornal do Brasil intitulada São Paulo. In: LISPECTOR, Clarice. A descoberta do mundo. $3^{\mathrm{a}}$ Ed. Rio de Janeiro: Francisco Alves, 1992. p. 148-149.

${ }^{137}$ GASPARI, Elio. A Ditadura Envergonhada, p. 330.

138 Apenas Pedro Aleixo, Magalhães Pinto e Rodon Pacheco tentaram abrandar o golpe. Sobre a reunião do CSN que decidiu o AI-5: GASPARI, Elio. A Ditadura Envergonhada, p. 333 - 343.

${ }^{139}$ ARQUIDIOCESE DE SÃO PAULO. Brasil: nunca mais, p. 62. $8^{\text {a }}$ Ed. Petrópolis: Vozes, 1985. 312 p.
} 
sob pena de estar faltando a compromissos que assumiu com o povo brasileiro" (preâmbulo do AI-5).

O AI-5 não possuía prazo para a sua vigência, de modo que os controles e suspensões das garantias constitucionais seriam permanentes. Era a primeira vez, desde o Estado Novo, que o Congresso encontrava-se fechado por tempo indeterminado. O Presidente poderia, ouvido o Conselho de Segurança Nacional e sem qualquer limitação constitucional, "suspender os direitos políticos de quaisquer cidadãos pelo prazo de 10 anos e cassar mandatos eletivos federais, estaduais e municipais" (art. $4^{\circ}$ ). A garantia de habeas corpus estaria suspensa "nos casos de crimes políticos, contra a segurança nacional, a ordem econômica e social e a economia popular" (art.10). O Ato Institucional excluía "de qualquer apreciação judicial todos os atos praticados de acordo com este Ato institucional e seus Atos Complementares, bem como os respectivos efeitos" (art. 11).

$\mathrm{O} \S 1^{\circ}$ do art. $5^{\circ}$ previa que "o ato que decretar a suspensão dos direitos políticos poderá fixar restrições ou proibições relativamente ao exercício de quaisquer outros direitos públicos ou privados”. De acordo com este parágrafo, o cidadão que tivesse seus direitos políticos suspensos poderia ser declarado legalmente como "morto", ou seja, incapaz de exercer os seus direitos mais básicos, tal como trabalhar com a Carteira, emitida pelo Ministério do Trabalho, assinada pelo empregador. Essa condição de "morto-vivo" permitia, inclusive, que o cônjuge recebesse pensão como "viúvo". Segundo um general cassado, entrevistado por Maria Helena Moreira Alves, o único direito que lhe restou era o pagamento do Imposto de Renda (IR). Ao longo dos dezesseis anos em que permaneceu cassado, ao preencher o formulário do IR, o general escrevia: "Estou morto". ${ }^{140}$

Nas palavras do Vice-Presidente da época, Pedro Aleixo: " $D a$ Constituição, que é antes de tudo um instrumento de garantia dos direitos da

${ }^{140}$ ALVES, Maria Helena Moreira. Op. cit. p. 65-66. 
pessoa humana, e da garantia dos direitos políticos não sobra (...) absolutamente nada." 141

Numa conferência realizada na Escola Superior de Guerra, Mário Pessoa analisa o AI-5:

Dentro do AI-5 não se encontram apenas normas repressivas, mas implicitamente toda a ideologia revolucionária brasileira, em preceitos concisos de alta densidade, sendo, nesse particular, mais afirmativo que a própria Constituição Federal em vigor. ${ }^{142}$

Três meses depois de editado o AI-5, o Decreto- lei $n^{0}$ 510, de 20 de março de 1969, que revogou parcialmente o DL 314, previa a possibilidade de prisão do indiciado em inquéritos políticos por até sessenta dias. Dez destes dias poderiam ocorrer em regime de incomunicabilidade. Essa previsão favorecia descaradamente a ação dos torturadores, que agiam cada vez mais sob a proteção das Leis de Segurança Nacional. O DL 510 visava suprir lacunas ou omissões do texto anterior, tornando puníveis, inclusive os atos preparatórios (art. 42), tendo sido editado com base no AI-5.

Em agosto de 1968, o Conselho de Segurança Nacional, cujo secretáriogeral era o chefe do Gabinete Militar de Costa e Silva, General Jayme Portella de Mello, aprovou o “Conceito Estratégico Nacional”, uma das bases do sistema repressivo. ${ }^{143}$ Este “Conceito” aprofundou a concepção já prevista no DL 314 e na Carta de 1967 na qual todo cidadão é responsável pela segurança nacional. Tratou também da relação entre guerra interna e segurança interna, constituindo uma base ideológica na qual se montaria o aparelho repressivo. Evidente que esse documento utiliza e difunde idéias estudadas e formuladas na Escola Superior de Guerra, facilmente encontradas no seu Manual Básico, mas que escritas através de documentos da cúpula militar do governo, empreende e concretiza o projeto autoritário desta mesma cúpula.

No ano de 1969, doze Atos Institucionais foram editados, uma Emenda Constitucional alterou profundamente a Carta de 1967, a Legislação de

\footnotetext{
${ }^{141}$ VENTURA, Zuenir. 1968- o ano que não terminou, p. 242. $3^{\text {a }}$ Ed. São Paulo: Editora Planeta do Brasil, 2008. 284 p.

${ }_{142}$ FRAGOSO, Augusto. Op. cit., p. 17.

${ }^{143}$ FICO, Carlos. 1968: o ano que terminou mal, p. 233.
} 
Segurança Nacional foi modificada três vezes e uma isquemia cerebral afastou o Marechal Costa e Silva da Presidência. Antes de adoecer, o Presidente já planejava outorgar uma nova Constituição, baseada num projeto do VicePresidente Pedro Aleixo. A Constituinte formada por oito pessoas, o Presidente, o Vice-Presidente, três ministros e três juristas, reuniu-se em julho de $1969^{144}$. A Carta não chegou a ser outorgada pelo Presidente, mas por uma junta militar encarregada de substituí-lo, enquanto permanecesse doente.

A junta militar composta por Augusto Rademaker, Aurelio de Lyra Tavares e Márcio de Souza e Mello foi a forma encontrada pelos militares para impedir a posse do Vice-Presidente Pedro Aleixo. A idéia de compor uma junta partiu do General Jayme Portella de Mello, chefe do Gabinete Militar de Costa e Silva. Para justificar tal anomalia, Carlos Medeiros da Silva, ex-ministro da Justiça, redigiu o AI-12 de $1^{\circ}$ de setembro de 1969.

Vinte oito dias depois da edição do AI-12, no dia 29 de setembro de 1969, a junta militar alterava, novamente, a Legislação de Segurança Nacional. O DL 898 era a representação máxima, depois do AI-5, da linha dura. Era também uma rígida resposta ao seqüestro do embaixador americano, Charles Burke Elbrick, ocorrido no início de setembro de 1969, embora, assim como as leis anteriores, revele profunda confiança no efeito preventivo da ameaça penal. Os primeiros artigos mantêm a estrutura da lei anterior, definindo segurança nacional, guerra revolucionária e guerra psicológica, segundo os preceitos da ESG. De acordo com o art. $7^{\circ}$, esses conceitos deveriam inspirar os juízes ou tribunais na aplicação da legislação.

O DL 898 utilizou a previsão da pena de morte do art. $150 \S 11$ da Carta de 1967. Para crimes que resultassem em morte, em alguns casos, a única pena prevista era a de morte, em outros casos, a pena mínima era a prisão perpétua e a máxima era a pena de morte, revelando uma política que pretendia intimidar e assustar. O art. 22, por exemplo, prevê que "exercer violência de qualquer natureza, contra Chefe de Governo estrangeiro, quando em visita ao Brasil ou de

\footnotetext{
${ }^{144}$ GASPARI, Elio. A ditadura escancarada, p. 75-76. $5^{\mathrm{a}}$ reimpressão. São Paulo: Companhia das Letras, 2009. $507 \mathrm{p}$.
} 
passagem pelo território brasileiro" possui a pena de prisão perpétua. Se resultasse em lesão corporal ou morte, a única pena prevista é a de morte. O art. 124 prevê que a pena de morte será executada trinta dias, após ser comunicada ao Presidente da República, e “se este não a comutar em prisão perpétua, a sua execução obedecerá ao disposto no Código de Justiça Militar.”

O DL 898 prevê penas que em nada correspondem com a gravidade do malefício. O art. 39, por exemplo, pune os crimes de manifestação do pensamento com a pena mínima de 10 anos. Heleno Fragoso, em seu artigo Lei de Segurança Nacional, esclarece:

A eficiência da repressão não depende da gravidade das penas, mas, sim, da certeza da punição. As penas desproporcionais e injustas, que ferem a consciência do julgador, não são aplicadas. A Justiça Militar jamais aplicou o artigo 39 e nunca impôs a pena de morte. ${ }^{145}$

O DL 314 e o DL 510 estabeleciam constituir propaganda subversiva o comício, desfile ou a passeata. O DL 898 mantém essa previsão no seu art. 45, de modo que, tal como exposto no texto, qualquer comício, desfile ou passeata, independente do conteúdo que apresentem, são consideradas propagandas subversivas. Podemos entender, então, que a simples reunião de pessoas configura crime contra a segurança nacional. A greve proibida também é prevista como propaganda subversiva. Já a greve lock-out, que acarreta paralisação de serviços públicos ou atividades essenciais, é prevista no art. 38, podendo cominar de 4 a 10 anos de reclusão.

O rigor com que a greve é tratada serve para justificar a violência da polícia contra os trabalhadores, já que não há qualquer finalidade políticosubversiva na paralisação do trabalho ${ }^{146}$. Desde o Código Penal de 1890, a greve é considerada crime passível de prisão. Com exceção de um breve período em 1946, jamais haverá liberdade de greve no Brasil até a Constituição de 1988. A ditadura, no entanto, facilita a repressão e a violência contra esses movimentos sociais, prendendo os principais líderes sindicais, proibindo associações e

\footnotetext{
${ }^{145}$ FRAGOSO, Heleno. Lei de Segurança Nacional, p. 230. In: Encontros com a civilização brasileira. Volume 2. Rio de Janeiro: Civilização Brasileira, 1978, p. 229-246.

${ }^{146}$ Ibid. p, 242.
} 
desarticulando agressivamente qualquer manifestação que expresse a luta dos trabalhadores.

O DL 898 mantém o período de incomunicabilidade por dez dias, e prevê o recurso de ofício para os casos de rejeição da denúncia e de sentença absolutória. No seu conjunto, o DL 898 possibilita a tortura na fase de inquérito, durante os dez dias de incomunicabilidade, torna as partes desiguais na fase judicial e prevê penas aberrantes.

A Emenda Constitucional n ${ }^{\circ}$ 1, de 17 de outubro de 1969, conhecida como Carta de 1969, foi produto de um poder usurpado pelos militares que, ao impediram a posse do Vice-Presidente Pedro Aleixo, criaram uma junta militar composta por três oficiais da alta cúpula. Essa junta exercia as suas funções sem aprovação do Congresso, logo agia sem qualquer legitimidade democrática, mesmo a puramente formal, que existe num Congresso amordaçado e limitado pelo Executivo. ${ }^{147}$

$\mathrm{O}$ art. $8^{\circ}$ da EC 1 inclui o binômio desenvolvimento e segurança, elaborado na ESG, ao prever o planejamento do desenvolvimento e da segurança nacional como competências da União, modificando o art. $8^{\circ}$ da Carta de 1967, que falava apenas em "planejar e garantir a segurança nacional.” A nova redação é a seguinte:

Art. $8^{\circ}$ Compete à União:

IV - organizar as fôrças armadas;

V - planejar e promover o desenvolvimento e a segurança nacionais;

$\mathrm{O}$ art. 32 restringe drasticamente as imunidades parlamentares, mesmo se comparado com a Carta de 1967. Os Deputados e Senadores eram invioláveis, no exercício do mandato, por suas opiniões, palavras e votos, "salvo nos casos de injúria, difamação ou calúnia, ou nos previstos na Lei de Segurança Nacional.” O art. 34 da Carta de 1967 previa que “os Deputados e Senadores são invioláveis no exercício de mandato, por suas opiniões, palavras e votos”, não estipulando, portanto, qualquer limitação à inviolabilidade dos parlamentares. O art. 32

${ }^{147}$ Ibid. p, 230. 
também exclui a previsão do art. 34 da Carta de 1967, na qual os parlamentares não poderiam ser presos criminalmente sem prévia licença da Câmara.

A EC 1 mantém uma seção dedicada à Segurança Nacional e uma seção dedicada às Forças Armadas. Mantém também, no art. 86, o preceito que "toda pessoa, natural ou jurídica, é responsável pela segurança nacional, nos limites definidos em lei.” A definição do Conselho de Segurança Nacional é modificada, assim como algumas das suas atribuições. O art. 87 prevê que "o Conselho de Segurança Nacional é o órgão de mais alto nível na assessoria direta ao Presidente da República, para formulação e execução da política de segurança nacional.” A Constituição anterior previa apenas que o CSN assessoraria o Presidente na formulação e na conduta da segurança nacional (art. 90). Essa mudança tem como pano de fundo a importância que o CSN foi adquirindo ao longo da ditadura. Dentre as suas competências, houve mudanças nos incisos I, II e VI, que passaram a vigorar com a seguinte redação:

\footnotetext{
Art. 89. Ao Conselho de Segurança Nacional compete:

I - estabelecer os objetivos nacionais permanentes e as bases para a política nacional;

II - estudar, no âmbito interno e externo, os assuntos que interessem à segurança nacional;

VI - conceder licença para o funcionamento de órgãos ou representações de entidades sindicais estrangeiras, bem como autorizar a filiação das nacionais a essas entidades.
}

A terminologia desenvolvida na ESG é claramente utilizada neste artigo com as expressões "objetivos nacionais permanentes" e "estudar, no âmbito interno e externo, os assuntos que interessam à segurança nacional.” Verifica-se, portanto, a introjeção dos conceitos desenvolvidos na ESG que aparecem, após 1964, em diversas legislações da época. A repercussão desses conceitos vai crescendo, na medida em que eles mesmos vão sendo mais bem desenvolvidos e difundidos, dentro e fora da corporação militar.

O art. 129 reproduz a redação dada pelo AI-6, de $1^{\circ}$ de fevereiro de 1969, à Carta de 1967, que retira a possibilidade de recurso ordinário para o STF em casos de crimes contra a segurança nacional ou contra as instituições militares. Essa modificação trazida pelo AI-6 mantém na Justiça Militar, unicamente, a competência para processar e julgar civis nos crimes contra a segurança nacional. 
A mudança era um pedido que a chamada linha dura fazia desde 1964, ou seja, excluir o STF do julgamento desses crimes, já que muitas vezes seus ministros abrandavam as penas das instâncias militares.

Ocorre que, no art. 119, que define a competência do STF, manteve-se a redação da Carta de 1967, que incluía o recurso ordinário em casos de crime contra a segurança nacional. Dessa forma, muitos civis conseguiram interpor recurso ordinário para o STF, mesmo após a vigência do AI-6.

O art. 182 previa a possibilidade do Presidente, ouvido o Conselho de Segurança Nacional, decretar a cassação da vigência de qualquer Ato Institucional.

Art. 182. Continuam em vigor o Ato Institucional n ${ }^{\circ}$ 5, de 13 de dezembro de 1968, e os demais Atos posteriormente baixados.

Parágrafo único. O Presidente da República, ouvido o Conselho de Segurança Nacional, poderá decretar a cessação da vigência de qualquer dêsses Atos ou dos seus dispositivos que forem considerados desnecessários.

O Alto Comando das Forças Armadas, em meio à anarquia militar instaurada desde o afastamento do Marechal Costa e Silva, decidiu pela sua substituição por um Presidente com mandato de quatro anos. Este presidente era o General Emílio Garrastazú Medici. Num discurso ocorrido na Escola Superior de Guerra, Medici afirmou: “haverá repressão, sim. E dura, e implacável.” ${ }^{148}$ De fato, em menos de três anos do seu governo, a máquina repressiva havia matado 120 pessoas e acumulava cerca de 2.500 denúncias de tortura. ${ }^{149}$

Em 1970, o General Medici e o Ministro do Exército, General Orlando Geisel, criaram o Destacamento de Operações de Informações - Centro de Operações de Defesa Interna, o DOI-CODI, um dos maiores símbolos de truculência e criminalidade da ditadura militar.

O Exército, a partir de 1970 com a criação do DOI, assumiu o comando das atividades de segurança, prevalecendo sobre a administração civil e sobre a Marinha e a Aeronáutica. Para cristalizar esse projeto centralizador foi criado o Sistema de Segurança Interna, no qual todos os órgãos da administração pública

\footnotetext{
${ }^{148}$ GASPARI, Elio A ditadura escancarada, p. 160.

${ }^{149}$ Ibid, p. 26.
} 
ficariam sujeitos ao comando unificado da repressão política. Estabeleceu-se também que o Centro de Informações do Exército, o CIE, criado em 1967 pelo presidente Costa e Silva, seria o órgão principal do Exército para assuntos de informação. ${ }^{150}$

Os comandantes dos DOIs eram tenentes-coronéis ou majores. Nas suas funções foram combinadas informação, operação, carceragem e serviço jurídico. Na sua estrutura, possuía quatro seções: investigação, informações e análise, busca e apreensão. Na seção de investigação, o objetivo era seguir suspeitos, encontrar esconderijos, procurar pistas. A seção de busca e apreensão lidava com as prisões e com o trabalho de rua. À seção de informações e análise foi designado o "porão", aonde os interrogatórios e torturas aconteciam.

A criação dos DOIs integrou o processo de distorção da estrutura da corporação militar que, desde 1964, gerava desordem e corrompia a hierarquia na instituição. Dentro da máquina repressiva, quem se destacava como superior era o major do DOI. Havia apenas uma tímida recomendação para que os DOIs fossem subordinados aos coronéis que chefiavam as seções de informações ${ }^{151}$. Os oficias das Forças Armadas estavam associados à polícia na construção de um mecanismo de repressão, na qual a tortura lhes parecia inevitável, sendo incluída em currículos de formação de militares. Segundo o livro Brasil: nunca mais ${ }^{152}$, havia quase uma centena de modos diferentes de tortura.

Dos manuais da ESG à prática da segurança interna, o que se verifica é a desfiguração dos oficiais das Forças Armadas que introjetaram a violência como forma usual de interrogatório, e usaram de uma suposta insegurança, que amedrontava o País, para agirem arbitrariamente à custa do Judiciário e do Legislativo, ambos amordaçados pela ditadura. Com a entrada do Exército nas delegacias e da tortura nos quartéis houve a policialização das instituições militares com custos sociais altíssimos. Nas palavras de Elio Gaspari:

\footnotetext{
${ }^{150}$ GASPARI, Elio A ditadura escancarada, p. 176-177.

${ }^{151}$ Ibid. p. 186

${ }^{152}$ ARQUIDIOCESE DE SÃO PAULO. Op. cit., p. 34.
} 
O que se apresentou como uma militarização das operações policiais tornou-se uma policialização das operações militares. O delegado Sérgio Fleury não ficou parecido com um oficial do Exército. Eram os oficiais do Exército que ficaram parecidos com ele. ${ }^{153}$

A montagem administrativa de uma estrutura capaz de combinar informações e repressão estava incluída na Política de Segurança Nacional com ênfase na Segurança Interna. Por meio de uma série de documentos secretos, dentre eles, o Planejamento de Segurança Interna, pelo qual o Presidente Medici criou o Sistema de Segurança Interna, o Sissegin, foi criada toda uma malha organizativa que produziu um complexo sistema de controle e repressão. ${ }^{154}$

Integrando essa rede de organizações havia os Departamentos de Ordem Pública e Social nos estados, os Dops, os DOI-Codi nos comandos militares, o Centro de Informação da Aeronáutica (CISA), o Centro de Informações do Exército (CIE) e o Centro de Informações da Marinha (Cenimar). Havia ainda agências como a Operação Bandeirante, a OBAN, criada com a Diretriz para a Política de Segurança Interna, documento expedido pela presidência em julho de $1969^{155}$. A OBAN era financiada por empresários, e na prática era vinculada ao comandante do II Exército, com sede na cidade de São Paulo. A OBAN funcionava sob a coordenação do CIE, órgão do gabinete do ministro. As delegacias policiais, inclusive o Dops, eram obrigadas a enviar à OBAN todos os suspeitos de atividades “terroristas”.

Em 1970, com a estrutura repressiva pronta, o processo coercitivo de desmobilização política chegava ao auge. Em 1964, a preocupação era expurgar quem tivesse alguma ligação com o governo anterior ou que fosse considerado esquerdista aos olhos do novo regime vigente: sindicalistas, estudantes, intelectuais. A chamada “operação limpeza” transbordou para uma parte da militância liberal, depois para dentro do próprio movimento conservador. Primeiro, foram amordaçados aqueles que, em 1964, vislumbravam chegar à

\footnotetext{
${ }^{153}$ GASPARI, Elio. A ditadura escancarada, p. 67.

${ }^{154}$ Ibid. p. $176-177$

${ }^{155}$ Ibid. p. 60
} 
Presidência, depois os partidos políticos foram extintos, substituídos por um sistema bipartidário, composto pelo MDB e pela ARENA. Restaria apenas descaracterizar as instituições que pareciam preservadas. O Congresso foi fechado duas vezes, e 281 parlamentares foram cassados, 105 depois do AI-5 ${ }^{156}$. Os que restaram, tinham suas imunidades parlamentares limitadas, e poderiam ser presos criminalmente sem autorização da Câmara. O Supremo Tribunal Federal foi diluído em 1965 com o AI-2 e, em 1968, após o AI-5, três dos seus ministros foram expurgados: Vitor Nunes Leal, Hermes Lima e Evandro Lins e Silva. Os ministros Antônio Gonçalves de Oliveira e Antônio Carlos Lafayete de Andrada demitiram-se.

Diversas vezes foi repetido que haveria um retorno às instituições democráticas, mas elas passaram a existir basicamente no papel, enquanto uma forte estrutura era criada para impedir o seu funcionamento. Cada movimento da oposição era usado como pretexto para endurecer o regime, de modo a fazer com que as instituições democráticas fossem esquartejadas em vida. Segundo Joseph Comblin $^{157}$, a máquina de segurança nacional é capaz de anular todas as outras forças do Estado e se impõem cada vez que é preciso tomar uma decisão importante. A próxima decisão era a sucessão presidencial do General Medici, marcada para março de 1974.

\subsection{4-1985: a segurança nacional sai de cena}

O General Ernesto Geisel foi lançado oficialmente candidato da Arena à Presidência em 18 de junho de 1973. Foi eleito Presidente com 400 votos contra 76 do "anticandidato" do MDB, Ulisses Guimarães, em 15 de janeiro de $1974 .{ }^{158}$ Desde 1952, o General Geisel era membro permanente da Escola Superior de Guerra. Na Presidência, nomeou o General Golbery para a chefia da Casa Civil, e juntos programaram a chamada distenção lenta, segura e gradual, culminando na

\footnotetext{
${ }^{156}$ Ibid. p. 227

${ }^{157}$ COMBLIN, Joseph. Op. cit., p. 160.

${ }^{158}$ D’ARAUJO, Maria Celina; CASTRO, Celso. Dossiê Geisel, p. 18. 3ª Ed. Rio de Janeiro: FGV, 2002. $251 \mathrm{p}$.
} 
saída dos militares do poder, na eleição de 1985, no fim do mandato do General João Batista Figueiredo. Ambos os generais, Geisel e Golbery, tinham o objetivo de desmontar a ditadura que ajudaram a construir por lhe faltar ordem e hierarquia, princípio basilar das Forças Armadas. Os responsáveis por supostamente instaurarem a ordem no País viviam num estado constante de anarquia nos quatéis e violência nas prisões. Nas palavras de Castello Branco: "Criar uma ditadura é fácil, mas é difícil acabar com ela." 159

O governo Geisel mesclou medidas autoritárias e liberalizantes. A oposição política, representada pelo MDB e pelos setores de esquerda, queria a democratização do País. Já a linha dura militar sempre se opôs a medidas liberalizantes e defendia a continuidade da ditadura. Em alguns momentos, Geisel reprimiu a oposição, em outros, a linha dura. ${ }^{160}$

Em 1976, Manoel Fiel Filho, operário, foi morto nas dependências do DOI do II Exército, mas dado como suicida pelos agentes do DOI, o $39^{\circ}$ suicida do regime. O 38 era o jornalista Vladimir Herzog, morto em 1975. Ao contrário da morte de Herzog que teve ampla repercussão, a morte do metalúrgico foi acobertada pelo II Exército. Nenhuma nota oficial foi emitida, e os órgãos de informação mantiveram o Presidente e o Ministro do Exército longe do assunto. A notícia do assassinato foi dada a Geisel pelo Governador de São Paulo, Paulo Egydio. Da morte do operário, o General Geisel tirou duas conclusões. A primeira foi demitir Ednardo D'Avila Mello, tirando-o do comando do II Exército. A segunda era a exoneração do chefe do CIE, o General Confucio Danton de Paula Avelino ${ }^{161}$. O problema para o Presidente não estava relacionado com os Direitos Humanos, mas com a disciplina militar, que perdia seu rumo. O SNI confundia insubordinação com confiança:

A bem da verdade é necessário que se afirme ter sido observada uma falta de coordenação entre os centros de informações militares ou até mesmo entre o CIE e os

\footnotetext{
${ }^{159}$ GASPARI, Elio. A ditadura envergonhada, p. 257.

${ }^{160}$ D’ARAUJO, Maria Celina; CASTRO, Celso. Op. cit. p. 8

${ }^{161}$ GASPARI, Elio. A ditadura encurralada, p. 176-215. São Paulo: Companhia das Letras, 2004. 525 p.
} 
DOIs ou, o que será mais nocivo, uma falta de confiança em informar aos escalões superiores a verdade quando um elemento é preso para averiguação. ${ }^{162}$ (grifo nosso)

Em abril de 1974, as cassações dos direitos políticos feitas em 1964 começariam a caducar. Em outubro, seriam eleitos indiretamente 22 Governadores, e em novembro, em eleição direta, um terço do Senado, toda a Câmara dos Deputados e todas as Assembléias Legislativas. Os resultados foram desfavoráveis ao regime. O CIE já havia aniquilado “os terroristas”, deixado o Araguaia ao silêncio da floresta, cabendo-lhe agora procurar conexões entre o Partido Comunista e o MDB. O CIE queria associar a vitória de Quércia em São Paulo, Paulo Brossard no Rio Grande e Roberto Saturnino no Rio de Janeiro à participação comunista nas eleições. Paralelamente, diversos panfletos começaram a ser distribuídos pelos quartéis contra o governo e, principalmente, contra o General Golbery. Era a linha dura que começava a sua ofensiva contra o processo de abertura, que considerava uma traição. Num informe do CIE, chegou-se a dizer que: "entregar o poder ao MDB não é o mesmo que entregar o país ao comunismo internacional?” 163

A partir de 1977, as dissidências dentro das Forças Armadas, em relação ao rumo da ditadura, eram explícitas. Em 1976, o Bispo de Nova Iguaçu, D. Adriano Hipólito, foi seqüestrado por homens encapuzados e espancado. Seu carro foi explodido em frente à sede da Conferência Nacional dos Bispos do Brasil. Na mesma época, bombas explodiram na OAB, na ABI (Associação Brasileira de Imprensa) e no CEBRAP (Centro Brasileiro de Análise e Planejamento), para citar apenas alguns casos. Essas ofensivas, perpetradas por agentes dos órgãos de tortura, culminaram, em 1981, num atentado no Riocentro. Dois militares que preparavam um atentado à bomba, durante as comemorações de $1^{\circ}$ de maio, sofreram um acidente quando a bomba explodiu dentro do próprio carro onde estavam. O sargento morreu e o capitão ficou gravemente ferido.

O CIE julgava que qualquer manifestação no País era fruto de uma associação com Moscou. Com o meio universitário não foi diferente. Após as

\footnotetext{
${ }^{162}$ GASPARI, Elio. A ditadura derrotada, p. 480.

${ }^{163}$ Ibid., p. 107.
} 
eleições de 1974, a sociedade voltava a se mobilizar. Surgia uma nova militância esquerdista de universitários que não tinham relação nenhuma com a luta armada dos anos 1960. Da deposição de João Goulart e da edição do AI-5, tinham poucas lembranças. Em abril de 1975, universitários da Escola de Comunicações e Artes da Universidade de São Paulo desencadearam uma greve. Em março e abril de 1976, foram os estudantes de Minas Gerais, Rio de Janeiro e Bahia que organizaram a paralisação. Em 1977, a PUC do Rio de Janeiro reuniu cerca de cinco mil pessoas debaixo dos seus pilotis e fez uma greve de dois dias ${ }^{164}$. Em abril desse mesmo ano, o General Geisel reuniu o Conselho de Segurança Nacional. Utilizando o AI-5, fechou o Congresso Nacional e promulgou a Emenda Constitucional n ${ }^{\circ}$ 8, conhecida como Pacote de Abril.

O Congresso estaria fechado supostamente porque votou contra as reformas do judiciário, propostas pela ARENA. O governo estava preocupado, no entanto, com os dispositivos político-eleitorais da Constituição. A EC 8, entre outras mudanças, tornou indireta a eleição para Governador e estendeu para seis anos o mandato dos sucessores à Presidência (art. $13 \S 2^{\circ}$ e art. $75 \S 3^{\circ}$ ). A escolha de um dos dois senadores, que seriam eleitos em 1978, também foi tornada indireta (art. $41 \S 2^{\circ}$ ). O quórum para a aprovação de emendas constitucionais passou de dois terços para a maioria absoluta do Congresso (art. 48). O General Golbery chegou a propor o abrandamento da Lei de Segurança Nacional e a revogação do AI-5, propostas recusadas pelo Presidente Geisel. ${ }^{165}$

A nova Lei de Segurança Nacional foi promulgada no final de 1978. Entre a edição do DL 898, em 1969, e a publicação da Lei no 6620 em 17 de dezembro de 1978, algumas mudanças foram feitas na Legislação de Segurança Nacional. $\mathrm{Na}$ sua maioria, incluíam novos crimes, tais como os crimes de contrabando e transportes de terroristas e subversivos praticados por meio de aeronaves, regulado pelo Decreto- lei 975 de 20 de outubro de 1969, e o apoderamento e controle de aeronave definido na Lei no 5786 de 27 de junho de 1972.

\footnotetext{
164 Ibid. p. 332.

165 Ibid. p. 353-367.
} 
A Lei 6620/1978 foi aprovada por decurso de prazo, ou seja, sem a participação do Congresso Nacional. No seu conjunto, tenta atenuar o DL 898, embora busque aprimorar o conceito de segurança nacional. Logo após a sua publicação, Heleno Fragoso publicava um artigo na Revista de Direito Penal pedindo a revogação da lei ${ }^{166}$. O jurista alertava para a impossibilidade do retorno à democracia enquanto uma Lei de Segurança Nacional continuasse em vigor, dado o seu caráter explicitamente antidemocrático, falando, inclusive, em terrorismo penal. Condenava a aplicação de Leis de Segurança Nacional para punir os participantes em greves, como ocorreu em Santo André e Diadema, em São Paulo.

Heleno Fragoso explica que não existe uma figura de delito denominada terrorismo. A expressão se aplicaria "a um conjunto de crimes contra a segurança do Estado, que se caracterizam por causar dano considerável a pessoas ou coisas, pela criação real ou potencial de terror ou intimidação, com finalidade políticosocial.” ${ }^{167}$ Dessa forma, haveria também o "terrorismo de direita" que visava manter as ditaduras militares no poder, vinculando-se a um projeto de endurecimento constante do regime. Para o jurista a solução é: "democracia, liberdade, justiça social.” 168

$\mathrm{Na}$ nova lei verifica-se uma mudança na conceituação de segurança nacional. $\mathrm{O}$ art. $2^{\circ}$ prevê que "Segurança Nacional é o estado de garantia proporcionado à Nação, para a consecução dos seus objetivos nacionais, dentro da ordem jurídica vigente.” No seu parágrafo único, exemplifica alguns dos objetivos nacionais, tais como soberania nacional, paz social, harmonia internacional e integridade territorial.

A Lei 6620/1978 retirava do ordenamento a previsão de pena de morte, mantendo como pena máxima, trinta anos de reclusão. Na fase de inquérito, o indiciado poderia permanecer preso por até sessenta dias, oito em regime de

\footnotetext{
${ }^{166}$ FRAGOSO, Heleno. Sobre a Lei de Segurança Nacional. In: Revista de Direito Penal no30. Julhodezembro de 1980. Disponível em: http://www.fragoso.com.br/escritorio.asp. Acesso em 20 de abril. 2010.

${ }^{167}$ Ibid. p, 9 -10.

${ }^{168}$ Ibid. p, 10.
} 
incomunicabilidade, ou seja, apenas dois dias a menos que as leis anteriores. $\mathrm{O}$ $\S 4^{\circ}$ do art. 53 previa que “em qualquer fase do inquérito a defesa poderá solicitar ao encarregado do inquérito que determine exame na pessoa do indiciado para verificação de sua integridade física.”

No dia $1^{\circ}$ de janeiro de 1979, entrava em vigor a Emenda Constitucional $\mathrm{n}^{\mathrm{o}} 11$ que, em seu art. $3^{\circ}$, revogava todos os Atos Institucionais e Complementares, no que fossem contrários à Constituição Federal, "ressalvados os efeitos dos atos praticados com bases neles, os quais estão excluídos de apreciação judicial”. O habeas corpus estava de volta, a segurança nacional da Escola Superior de Guerra saía de cena. Sobre a revogação do AI-5, o General Augusto Fragoso, numa conferência na ESG, posiciona-se:

Há os otimistas, sinceros sem dúvida, que julgam ter sido desnecessária a edição desse Ato, em dezembro de 1968 (...). Há os malévolos, meros oposicionistas ou contestadores desabusados ou encapuçados, que defendem, agora, a revogação pura e simples do AI-5, sem que medidas, da mesma índole das que alí se contêm, sejam inseridas na Lei Magna ou na legislação ordinária, como se a cessação da vigência desse Ato devesse ser o passo inicial da distensão no campo político. ${ }^{169}$

Os militares que discordavam da política do General Geisel, e distribuíam panfletos contra o General Golbery nos quartéis, apoiavam o General Sylvio Frota, ministro do Exército, candidato à Presidência contra a vontade de Geisel. No dia 12 de outubro de 1977, o Presidente demitiu o seu ministro de Exército, encerrando uma enorme desordem militar e restabelecendo a sua autoridade sobre as Forças Armadas. O próximo Presidente seria o chefe do SNI, General João Figueiredo. Segundo o livro Brasil:nunca mais:

Ao terminar o último ano do governo Geisel, a estatística do Regime Militar de 1964 registrava aproximadamente 10 mil exilados políticos, 4.682 cassados, milhares de cidadãos que passaram pelos cárceres políticos, 245 estudantes expulsos das universidades por força do Decreto 477, e uma lista de mortos e desaparecidos tocando a casa das três centenas. ${ }^{170}$

\footnotetext{
${ }^{169}$ FRAGOSO, Augusto. Op. cit., p. 16.

${ }^{170}$ ARQUIDIOCESE DE SÃO PAULO. Op. cit., p. 68.
} 
Com o General João Figueiredo na Presidência, a última Lei de Segurança Nacional do País e a Lei da Anistia foram promulgadas. A Lei no 7170 de 14 de dezembro de 1983 foi fruto de intensa mobilização, na qual participaram os partidos de oposição e diversas entidades compromissadas com a democracia. Segundo Heleno Fragoso ${ }^{171}$, em seu trabalho A Nova Lei de Segurança Nacional, a característica mais marcante da lei é o abandono da Doutrina de Segurança Nacional.

O art. $5^{\circ}$ da Lei 7170/1983 prevê a possibilidade de suspensão condicional de pena, novidade em relação às leis anteriores. $\mathrm{O}$ art. $7^{\circ}$ comete um equívoco ao prever a aplicação subsidiária do Código Penal Militar, já que a legislação militar deve caber aos militares, e não aos civis. A lei peca ao insistir em diversos termos preconceituosos e de difícil compreensão, tais como terrorismo, sabotagem, inconformismo político, subversão. Outro erro grave é manter a Justiça Militar como competente para julgar os crimes previstos na lei. A competência deveria ser da Justiça Comum. O período de incomunicabilidade previsto no art. $33 \S 2^{\circ}$ é de cinco dias improrrogáveis. A Lei 7170/1983 não fala em segurança nacional, retirando dos primeiros artigos as definições da ESG (segurança nacional, guerra revolucionária, guerra psicológica) presente nas leis anteriores. Nas palavras de Heleno Fragoso:

A nova lei de segurança representa um avanço notável que não pode deixar de surpreender os que se opõem ao sistema político em vigor. A doutrina de segurança nacional, elaborada pela Escola Superior de Guerra, parecia ser a alma do sistema. A nova lei tende a tornar raros os processos por crime contra a segurança do Estado. ${ }^{172}$

Desde o governo Geisel, as mudanças visando a transição política foram sempre tímidas. Elas ocorreram gradualmente, de modo que não comprometessem as Forças Armadas com o chamado revanchismo. Segundo Clóvis Brigagão ${ }^{173}$, os militares queriam garantir que sairiam incólumes dos

\footnotetext{
171 FRAGOSO, Heleno. A Nova Lei de Segurança Nacional, p. 1. Disponível em http://www.fragoso.com.br/escritorio.asp. Acesso em 20 de abril. 2010.

${ }^{172}$ Ibid. p, 7.

${ }^{173}$ BRIGAGÃO, Clóvis. A Militarização da Sociedade. p. 11. Jorge Zahar Editor: Rio de Janeiro. 1985. $94 \mathrm{p}$.
} 
desgastes e dos encargos que lhes foram atribuídos naquele período, traçando eles mesmos os rumos da retirada.

A Lei 6683/1979, a Lei da Anistia, trouxe os exilados de volta ao Brasil. Por outro lado, a anistia dos "crimes conexos" pretendia contemplar aqueles que, tendo implantado e conduzido a ditadura, não seriam punidos pelos atos arbitrários que cometeram. Além de encobrir os torturadores, a lei abrange todos os crimes praticados pelos militares por qualquer motivação política.

Em 1985, terminavam os longos 21 anos de ditadura militar no Brasil. A Doutrina de Segurança Nacional e Desenvolvimento saiu da Escola Superior de Guerra e expandiu-se nas instituições, quartéis, na mentalidade militar. Seria equivocado afirmar que a Doutrina foi expressa apenas nas Leis de Segurança Nacional. Acreditamos que ela, sendo fruto de um pensamento militar, foi amplamente difundida na época, marcando todas as ações que supostamente garantissem a segurança interna, inclusive a tortura.

Baseada num anticomunismo ferrenho, tantas vezes fantasioso, a segurança nacional teve uma íntima relação com o projeto autoritário militar. Ela foi criada num ambiente militar. Muitas vezes, concordamos, parecia esvaziada de sentido, quando refletimos sobre a possibilidade que havia do comunismo de fato firmar-se no Brasil. Parece ainda mais fragilizada quando mesmo depois de calada a imprensa, amordaçados o Legislativo e o Judiciário, mesmo depois de tantas prisões e torturas, ainda falava-se em "subversão" e "inimigo interno". A finalidade, muitas vezes, foi aniquilar com qualquer opositor do regime, qualquer que fosse a sua ideologia. Bastava discordar, criar "antagonismos”, e tanta outras vezes bastou ser estudante, operário, sindicalista, professor, parlamentar.

No final do regime, a violência dos atentados cometidos por agentes dos órgãos de tortura já mostrava a falta de finalidade das suas próprias ações. Foi pelo poder e pela manutenção da violência que esses atentados foram cometidos, e como tais não constituem finalidade alguma, mas arbitrariedade. E, "como a cegueira alcança tudo, porque nada compreende” ${ }^{174}$, não compreendiam que os

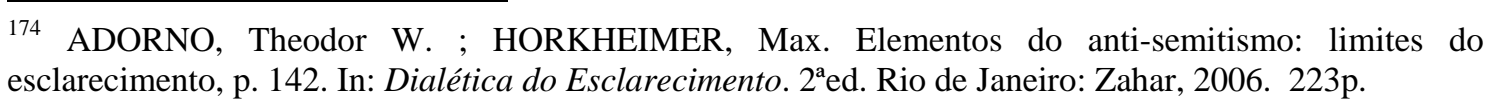


“antagonismos" fazem parte de qualquer país minimamente comprometido com a liberdade. 


\section{Conclusão}

A história brasileira é marcada por diversas intervenções militares. A partir da Constituição de 1891(1.2), aos militares é atribuída a missão de garantir as leis no interior e sustentar as instituições constitucionais. Esse papel é acentuado ao longo do tempo, iniciando um movimento de aumento de poder dos militares que passarão a chamar para si o dever de resguardar a segurança interna.

Diversas correntes ideológicas começam, durante a Primeira República, a perpassar as Forças Armadas (1.3), justificando o caráter intervencionista da instituição. A influência francesa do militar apolítico consegue alguns seguidores, mas não predomina nas Forças Armadas. A tendência, ao contrário, voltava-se para o controle do poder político que, ao mesmo tempo, regenerasse a sociedade civil. Esta concepção marcaria a corporação, e seria implementada, de fato, na ditadura militar.

Entendemos que a década de 1930 (1.4 e 1.5), com a Intentona em 1935 e o crescimento do sentimento anticomunista nas Forças Armadas, possibilitou a coesão e a construção de uma doutrina na corporação militar. O General Góes Monteiro, responsável pela elaboração dessa doutrina, tornou possível a definição do papel do Exército na sociedade brasileira. Segundo o General, era preciso fortalecer as Forças Armadas para que elas fossem as verdadeiras responsáveis pela segurança interna e externa do País.

Muitas das idéias enfatizadas no contexto da década de 1930 foram aprimoradas na Escola Superior de Guerra (2.1 e 2.2). A ESG tinha o clima da Guerra Fria envolvido na sua atuação e desenvolvimento. Do ambiente militar da Escola, saíram muitos oficiais que, em 1964, derrubaram João Goulart e deram início à ditadura (3.1, 3.2 e 3.3).

O fato da ESG ser a responsável pelo aperfeiçoamento da segurança nacional, que adquirindo contornos novos passou a ser chamada de Doutrina de Segurança Nacional e Desenvolvimento, demonstra a relação que os militares 
possuíam com o tema, assim como a sua missão de difundi-la e colocá-la em prática. Assumindo essas prerrogativas, os militares passam a ocupar todas as instâncias do processo de combate ao comunismo. Investigavam, informavam, julgavam, puniam, torturavam.

A mentalidade militar imbuída da idéia de missão "saneadora" da sociedade permitiu e acobertou a ação de oficiais nos calabouços da ditadura com custos altíssimos para a população e para a própria imagem da corporação militar, manchada pelos diversos abusos que cometeu.

A indisciplina e a desordem, criadas por essa mesma mentalidade, levaram dois generais, Golbery e Geisel, que participaram da construção da ditadura, a acabarem com ela.

A Doutrina de Segurança Nacional de Desenvolvimento permeou os 21 anos de ditadura, justificando, supostamente, que, para combater o "inimigo interno" e desenvolver economicamente o País, era preciso acabar com o Congresso Nacional em vida, desmobilizar a sociedade, extinguir os partidos políticos, diluir o STF para, depois, expurgar diversos dos seus membros, torturar, matar, desaparecer com os corpos das vítimas, promulgar Leis de Segurança Nacional aberrantes, editar Atos Institucionais.

Defendemos que, embora a segurança nacional associada aos militares já estivesse presente no contexto brasileiro anterior à criação da ESG, a forma como o conceito foi desenhado pela Escola, assim como a forma pela qual foi colocada em prática, com o golpe de 1964 e com o desenvolver da ditadura, revelam que a grande preocupação militar era o combate ao comunismo, e, portanto, o combate ao "inimigo interno", diferenciando-se, dessa forma, do conceito norte-americano de segurança nacional.

Nos anos 1960, foi possível para os militares, apesar das divergências internas, expressarem-se como um bloco, envolto num extravagante poder político. Com isso, alcançaram o objetivo de instaurar uma ditadura, enquanto a Doutrina de Segurança Nacional e Desenvolvimento lhe dava um propósito. 


\section{Bibliografia}

ADORNO, Theodor W. ; HORKHEIMER, Max. Dialética do Esclarecimento. $2^{\mathrm{a} e d .}$ Rio de Janeiro: Zahar, 2006. 223p.

ALVES, Maria Helena Moreira. Estado e Oposição no Brasil (1964-1984). $3^{\text {a }}$

Ed. Petrópolis: Vozes, 1985. 337 p.

ARQUIDIOCESE DE SÃO PAULO. Brasil: Nunca Mais. $8^{a}$ Ed. Petrópolis: Vozes, 1985. $312 \mathrm{p}$.

ARRUDA, Antônio de. A Escola Superior de Guerra: história de sua doutrina. $2^{a}$ Ed. São Paulo: GRD; Brasília: Instituto Nacional do Livro, 1983. 303 p.

BRIGAGÃO, Clóvis. A Militarização da Sociedade. Rio de Janeiro: Jorge Zahar, 1985. $94 \mathrm{p}$.

CAMARGO, Aspásia. O golpe silencioso: as origens da república corporativa. Rio de Janeiro: Rio Fundo, 1989. 279 p.

CARVALHO, José Murilo de. Forças Armadas e Política no Brasil. Rio de Janeiro: Jorge Zahar, 2005. 222 p.

COELHO, Edmundo Campos. Em Busca de Identidade: o Exército e a Política na Sociedade Brasileira. Rio de Janeiro: Forense Universitária, 1976. 207 p.

COMBLIN, Joseph. A Ideologia da Segurança Nacional - o poder militar na América Latina. $3^{\text {a }}$ Ed. Rio de Janeiro: Civilização Brasileira, 1980. 251 p. 
D’ARAUJO, Maria Celina; CASTRO, Celso. Dossiê Geisel. $3^{\mathrm{a}}$ ed. Rio de Janeiro: FGV, 2002. 251p.

D’ARAUJO, Maria Celina. Justiça Militar, Segurança Nacional e Tribunais de Exceção. Trabalho apresentado no $30^{\circ}$ encontro da ANPOCS, 24 a 28 de outubro de 2006. Caxambu, Minas Gerais.

DREIFUSS, René Armand. 1964: a conquista do Estado. $2^{\text {a }}$ Ed. Petrópolis: Vozes, 1981. 814 p.

ESCOLA SUPERIOR DE GUERRA. Manual Básico. Rio de Janeiro: ESG, 1975. $573 \mathrm{p}$.

ESCOLA SUPERIOR DE GUERRA. Fundamentos Teóricos. Rio de Janeiro: ESG, 1983. 332 p.

FAORO, Raymundo. Os Donos do Poder. $4^{\text {a }}$ Ed. São Paulo: Globo, 2008. 929 p.

FAUSTO, Boris. A Revolução de 1930- Historiografia e História. 16 ${ }^{\text {a }}$ Ed. São Paulo: Companhia das Letras, 1997. 159 p.

. Getúlio Vargas- O poder e o sorriso. São Paulo:

Companhia das Letras, 2006. 233 p.

FRAGOSO, Augusto. Legislação de Segurança Nacional. In: Revista do Superior Tribunal Militar. Brasília, nº1, p. 01-93, 13 de agosto de 1975.

FRAGOSO, Heleno. A Lei de Segurança Nacional. In: Encontros com a Civilização Brasileira nº 2. Rio de Janeiro: Civilização Brasileira, 1978. p. 229246. 
A Nova Lei de Segurança Nacional. Disponível em http://www.fragoso.com.br/escritorio.asp. Acesso em 20 de abril. 2010. . Para uma interpretação democrática da Lei de Segurança

Nacional. Disponível em http://www.fragoso.com.br/escritorio.asp. Acesso em 20 de abril. 2010. . Sobre a Lei de Segurança Nacional (6.620 de 17.12.1978).

Disponível em http://www.fragoso.com.br/escritorio.asp. Acesso em 20 de abril. 2010.

FICO, Carlos. 1968: o ano que terminou mal. In: FICO, Carlos; ARAUJO, Maria Paula (Org.). 1968- 40 anos depois. História e Memória. Rio de Janeiro: 7 Letras, 2009. p. 223- 239. . O Grande Irmão- da operação Brother Sam aos anos de chumbo. $2^{\mathrm{a} e d . ~ R i o ~ d e ~ J a n e i r o: ~ C i v i l i z a c ̧ a ̃ o ~ B r a s i l e i r a, ~ 2008 . ~} 334$ p.

FILHO, João Café. Do sindicato ao Catete. Rio de Janeiro: José Olympio, 1966. $320 \mathrm{p}$.

GASPARI, Elio. A Ditadura Encurralada. São Paulo: Companhia das Letras, 2004. 525 p.

. A Ditadura Envergonhada. 6 a reimpressão. São Paulo:

Companhia das Letras, 2009. 417 p.

. A Ditadura Derrotada. $2^{\mathrm{a}}$ reimpressão. São Paulo: Companhia das Letras, 2003. 538 p. 
. A Ditadura Escancarada. 5a reimpressão. São Paulo:

Companhia das Letras, 2009. 507 p.

LISPECTOR, Clarice. A descoberta do mundo. $3^{\text {a }}$ Ed. Rio de Janeiro: Francisco Alves, 1992. 533 p.

MARKUN, Paulo; HAMILTON, Duda. 1961: Que as Armas Não Falem. São Paulo: Senac, 2001. 410 p.

PESSOA, Mário. O Direito da Segurança Nacional. R: Biblioteca do Exército; São Paulo: Revista dos Tribunais, 1971. 356 p.

PILATTI, Adriano. A influência norte-americana na criação da Escola Superior de Guerra e na formulação da Doutrina de Segurança Nacional e Desenvolvimento brasileiras. Trabalho apresentado no curso de Mestrado da PUC - Rio. Novembro, 1985.

RAMOS, Graciliano. Memórias do Cárcere. $1^{\mathrm{o}}$ volume. $4^{\mathrm{a}}$ Ed. São Paulo: Editora Martins, 1960. 358 p.

RIBEIRO, Darcy. Aos Trancos e Barrancos- Como o Brasil deu no que deu. 2ªd. Rio de Janeiro: Guanabara, 1985. Páginas não declaradas.

ROUQUIÉ, Alain. O Estado Militar na América Latina. São Paulo: Alfa-Omega, 1984. $476 \mathrm{p}$.

SILVA, Hélio. 1937 - Todos os golpes se parecem. Rio de Janeiro: Civilização Brasileira, 1970. 618 p.

SODRÉ, Nelson Werneck. A História Militar do Brasil. $3^{\text {a }}$ Ed. Rio de Janeiro: Civilização Brasileira, 1979. 439 p. 
STEPAN, Alfred. Os Militares na Política. Rio de Janeiro: Artenova, 1975. 222 p.

VENTURA, Zuenir. 1968- o ano que não terminou. $3^{\mathrm{a}}$ Ed. São Paulo: Planeta do Brasil, 2008. 284 p. 


\section{ANEXO | 175}

\begin{tabular}{|c|c|c|}
\hline Manual da Escola Superior de Guerra & Decreto- lei 314 de 1967 & Lei 6620 de 1978 \\
\hline \multirow[t]{2}{*}{$\begin{array}{l}\text { Segurança Nacional é o grau de } \\
\text { garantia que, através de ações } \\
\text { políticas, econômicas, psicossociais e } \\
\text { militares, o Estado proporciona, em } \\
\text { determinada época, à Nação que } \\
\text { jurisdiciona para a conquista ou } \\
\text { manutenção dos Objetivos Nacionais, } \\
\text { a despeito dos antagonismos ou } \\
\text { pressões existentes ou potenciais. }\end{array}$} & $\begin{array}{l}\text { A segurança nacional é a } \\
\text { garantia da consecução dos } \\
\text { objetivos nacionais contra } \\
\text { antagonismos, tanto } \\
\text { internos como externos. }\end{array}$ & $\begin{array}{l}\text { Segurança Nacional é o estado de } \\
\text { garantia proporcionado à Nação, } \\
\text { para a consecução dos seus } \\
\text { objetivos nacionais, dentro da } \\
\text { ordem jurídica vigente. } \\
\text { Constituem objetivos nacionais, } \\
\text { especialmente: } \\
\text { - Soberania Nacional } \\
\text { - Integridade Territorial } \\
\text { - Regime Representativo e } \\
\text { - Democrático } \\
\text { - Paz Social } \\
\text { - Harmonidade Nacional } \\
\text { Hnternacional }\end{array}$ \\
\hline & $\begin{array}{l}\text { A segurança nacional } \\
\text { compreende, } \\
\text { essencialmente, medidas } \\
\text { destinadas à preservação da } \\
\text { segurança externa e interna, } \\
\text { inclusive a prevenção e } \\
\text { repressão da guerra } \\
\text { psicológica adversa e da } \\
\text { guerra revolucionária ou } \\
\text { subversiva. }\end{array}$ & $\begin{array}{l}\text { A segurança nacional } \\
\text { compreende, essencialmente, } \\
\text { medidas destinadas à preservação } \\
\text { da segurança externa e interna, } \\
\text { inclusive a prevenção e repressão } \\
\text { da guerra psicológica adversa e da } \\
\text { guerra revolucionária } \\
\text { subversiva. }\end{array}$ \\
\hline $\begin{array}{l}\text { Segurança interna, integrada na } \\
\text { segurança nacional, diz respeito aos } \\
\text { antagonismos ou pressões, de }\end{array}$ & $\begin{array}{l}\text { A segurança } \text { interna, } \\
\text { integrada na } \text { segurança } \\
\text { nacional, diz respeito às }\end{array}$ & $\begin{array}{l}\text { A segurança interna, integrada na } \\
\text { segurança nacional, diz respeito } \\
\text { às ameaças ou pressões }\end{array}$ \\
\hline
\end{tabular}

175 O DL 510 e o DL 898, ambos de 1969, repetem as definições previstas no DL 314 de 1967. A Lei 7170/1983 não prevê qualquer definição relacionada à segurança nacional. 


\begin{tabular}{|c|c|c|}
\hline $\begin{array}{l}\text { qualquer origem, forma ou natureza, } \\
\text { que se manifestem ou produzam } \\
\text { efeitos no âmbito interno do país. }\end{array}$ & $\begin{array}{l}\text { ameaças ou pressões } \\
\text { antagônicas, de qualquer } \\
\text { origem, forma ou natureza, } \\
\text { que se manifestem ou } \\
\text { produzam efeito no âmbito } \\
\text { interno do país. }\end{array}$ & $\begin{array}{l}\text { antagônicas, de qualquer origem, } \\
\text { forma ou natureza, que se } \\
\text { manifestem ou produzam efeito } \\
\text { no âmbito interno do país. }\end{array}$ \\
\hline $\begin{array}{l}\text { A guerra psicológica é o emprego } \\
\text { planejado da propaganda e da } \\
\text { exploração de outras ações, com o } \\
\text { objetivo de influenciar opiniões, } \\
\text { emoções, atitudes e comportamento } \\
\text { de grupos adversos ou neutros, de } \\
\text { modo a apoiar a consecução dos } \\
\text { objetivos nacionais. }\end{array}$ & $\begin{array}{l}\text { A guerra psicológica } \\
\text { adversa é o emprego da } \\
\text { propaganda, da } \\
\text { contrapropaganda e de } \\
\text { ações nos campos político, } \\
\text { econômico, psicossocial e } \\
\text { militar, com a finalidade de } \\
\text { influenciar ou provocar } \\
\text { opiniões, emoções, atitudes } \\
\text { e comportamentos de } \\
\text { grupos estrangeiros, } \\
\text { inimigos, neutros ou } \\
\text { amigos, contra a } \\
\text { consecução dos objetivos } \\
\text { nacionais. }\end{array}$ & $\begin{array}{l}\text { A guerra psicológica adversa é o } \\
\text { emprego da propaganda, da } \\
\text { contrapropaganda e de ações nos } \\
\text { campos político, econômico, } \\
\text { psicossocial e militar, com a } \\
\text { finalidade de influenciar ou } \\
\text { provocar opiniões, emoções, } \\
\text { atitudes e comportamentos de } \\
\text { grupos estrangeiros, inimigos, } \\
\text { neutros ou amigos, contra a } \\
\text { consecução dos objetivos } \\
\text { nacionais. }\end{array}$ \\
\hline $\begin{array}{l}\text { A guerra revolucionária comunista é } \\
\text { o conflito, normalmente interno, de } \\
\text { concepção marxista-leninista, } \\
\text { inspirado nesta ideologia, estimulado } \\
\text { e, até mesmo, auxiliado do exterior, } \\
\text { que utilizando intensivamente a ação } \\
\text { psicológica e todas as formas de } \\
\text { subversão e violência, visa à } \\
\text { conquista do poder pelo controle } \\
\text { progressivo da Nação. }\end{array}$ & $\begin{array}{l}\text { A guerra revolucionária é o } \\
\text { conflito interno, geralmente } \\
\text { inspirado em uma ideologia } \\
\text { ou auxiliado do exterior, } \\
\text { que visa à conquista } \\
\text { subversiva do poder pelo } \\
\text { controle progressivo da } \\
\text { Nação. }\end{array}$ & $\begin{array}{l}\text { A guerra revolucionária é o } \\
\text { conflito interno, geralmente } \\
\text { inspirado em uma ideologia ou } \\
\text { auxiliado do exterior, que visa à } \\
\text { conquista subversiva do poder } \\
\text { pelo controle progressivo da } \\
\text { Nação. }\end{array}$ \\
\hline
\end{tabular}


